I N T ER N ATIONAL MONETARY FUND

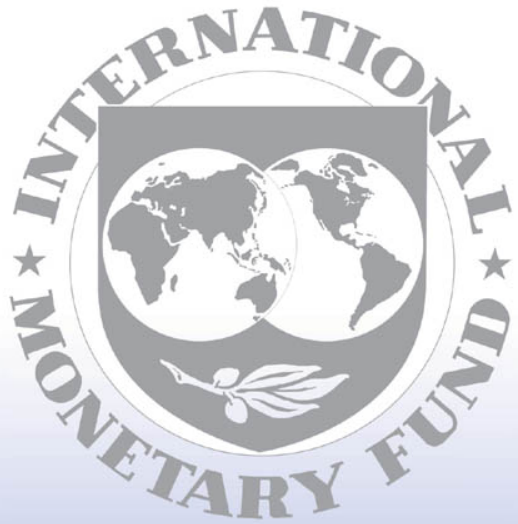

Staff

Country

Reports 


\section{Benin: Poverty Reduction Strategy Paper-Annual Progress Report}

Poverty Reduction Strategy Papers (PRSPs) are prepared by member countries in broad consultation with stakeholders and development partners, including the staffs of the World Bank and the IMF. Updated every three years with annual progress reports, they describe the country's macroeconomic, structural, and social policies in support of growth and poverty reduction, as well as associated external financing needs and major sources of financing. This country document for Benin, dated December 2004, is being made available on the IMF website by agreement with the member country as a service to users of the IMF website.

To assist the IMF in evaluating the publication policy, reader comments are invited and may be sent by e-mail to publicationpolicy@imf.org.

Copies of this report are available to the public from

International Monetary Fund • Publication Services

$70019^{\text {th }}$ Street, N.W. • Washington, D.C. 20431

Telephone: (202) 623-7430 • Telefax: (202) 623-7201

E-mail: publications@imf.org •Internet: http://www.imf.org

Price: $\$ 15.00$ a copy

\section{International Monetary Fund \\ Washington, D.C.}


REPUBLIC OF BENIN

NATIONAL COMMISSION FOR DEVELOPMENT AND THE FIGHT AGAINST POVERTY (CNDLP)

PROGRESS REPORT ON THE IMPLEMENTATION OF THE PRSP 2003

December 2004

(C)International Monetary Fund. Not for Redistribution 
LIST OF ACRONYMS AND ABBREVIATIONS...................................................................... 4

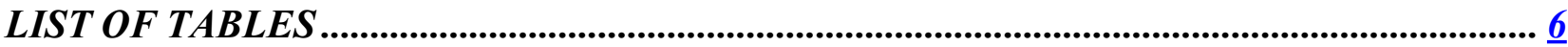

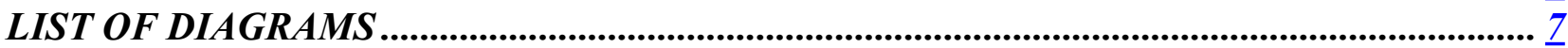

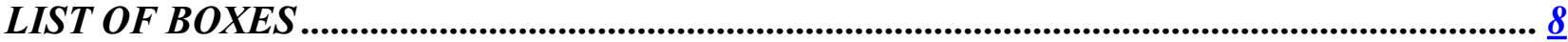

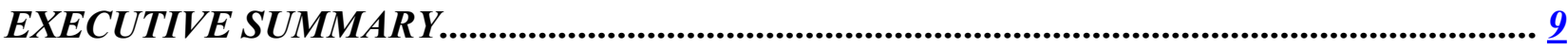

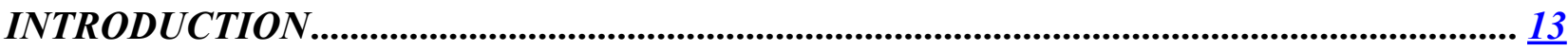

I. ANALYSIS OF POVERTY TRENDS AND ECONOMIC POLICIES IMPLEMENTED IN

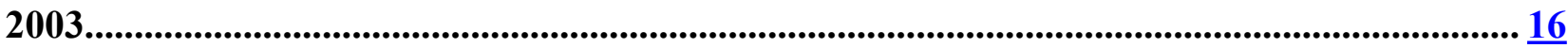

1.1 Poverty trends and progression relation to the overall PRSP objectives in $2003 \ldots \underline{16}$

1.2 TRENDS IN THE ECONOMIC SITUATION AT THE MACRO AND SECTORAL

LEVELS AND ANALYSIS OF POLICIES IMPLEMENTED IN 2003 ......................... 21

1.3 Trends in the status of human capital, environment and analysis of policies implemented in 2003 ...................................................................................................................... 30

1.4 Trends in Governance and institutional capacities and analysis of policies

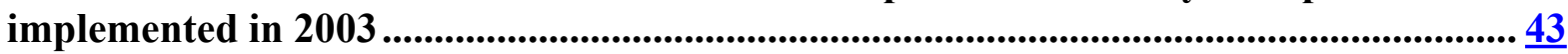

1.5 Trends in mutual support groups and the capacity of the poor to participate in decision-making and production and analysis of policies implemented in 2003............. 47

1.6 Cross-cutting Issues ..................................................................................................................... 49

II. PROGRESS REPORT ON THE IMPLEMENTATION OF PRSP MATRIX OF

MEASURES IN 2003 .......................................................................................................................... 52

2.1 PROGRESS MADE IN 2003 IN RESPECT OF AXIS 1 MEASURES:

STRENGTHENING OF MEDIUM TERM MACRAOECONOMIC FRAMEWORK $\underline{53}$

2.2 PROGRESS MADE IN RESPECT OF MEASURES UNDER AXIS 2: HUMAN

CAPITAL DEVELOPMENT AND ENVIRONMENTAL MANAGEMENT................. $\underline{55}$

2.3 PROGRESS MADE IN 2003 IN RESPECT OF MEASURES UNDER AXIS 3:

STRENGTHENING GOOD GOVERNANCE AND INSTITUTIONAL CAPACITY

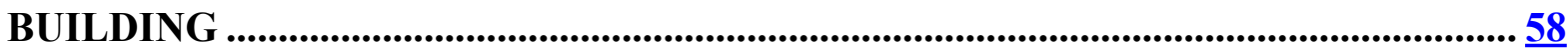

2.4 PROGRESS MADE IN 2003 IN RESPECT OF MEASURES UNDER AXIS 4;

PROMOTION OF SUSTAINABLE EMPLOYMENT AND CAPACITY BUILDING

FOR THE POOR TO ENABLE THEM TO PARTICIPATE IN DECISION-MAKING

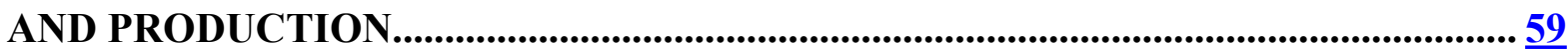

III. IMPLEMENTATION OF PRSP MONITORING AND EVALUATION MECHANISMS

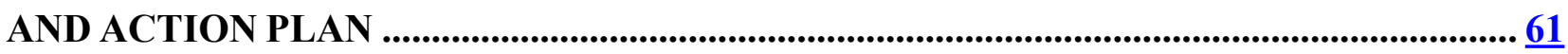

3.1 Developments in institutional framework in 2003 .............................................................. 61

3.2 ACTION PLAN FOR 2004 AND 2005 MONITORING \& EVALUATION

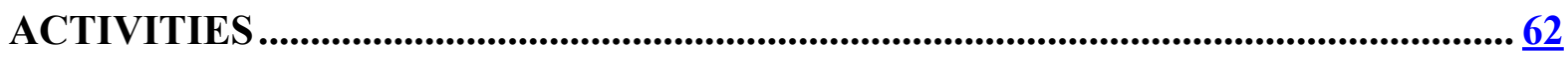

3.3. 2004 - 2005 ACTION PLAN ON STRENTHENING INFORMATION SYSTEMS

FOR PRSP MONITORING AND EVALUATION. ..$\underline{6}$

3.4 HUMAN AND MATERIAL CAPACITY BUILDING PLAN FOR PRSP

MONITORING AND EVALUATION IN 2004 AND 2005 ................................................... 69

3.5 2004 AND 2005 ACTION PLAN FOR POPULARISING THE PRSP AND

PROGRESS REPORT ON PRSP IMPLEMENTATION. 
Appendix 1: Proposed list of PRSP result and impact indicators for the 2003 report.

Appendix 2: Definition of indicators retained

Appendix 3: Rate of execution of budgeted recurrent expenditure excluding salaries of PERAC ministries for the 2001/ 2003 period. ( \%)

Appendix 4: Rate of execution of budgeted capital expenditure excluding salaries of PERAC ministries for the $2001 / 2003$ period. ( \%).

Appendix 5: Trends in the average time frame for payment of public expenditure

(type of expenditure by ministry)

Appendix 6 Level of implementation of PRSP matrix of measures, 2003- 2005. $\underline{83}$

Appendix 7 : Overall indices for the implementation of the matrix of measures... $\underline{100}$

implemented in $\mathbf{2 0 0 3}$ 


\section{LIST OF ACRONYMS AND ABBREVIATIONS}

\begin{tabular}{|c|c|c|}
\hline BCEAO & - & Banque Centrale des Etats de l'Afrique de l'Ouest \\
\hline BIPEN & - & Performance and Prospects of National Economy \\
\hline CAPE & - & Economic Policy Analysis Unit \\
\hline CDMT & - & Medium Term Expenditure Framework \\
\hline CIF & - & Cost Insurance Freight \\
\hline CNDLP & - & National Commission for Development and the fight ag \\
\hline $\mathrm{CNDLP} / \mathrm{PS}$ & - & Permanent Secretariat of the National Development and Poverty \\
\hline
\end{tabular}

$\begin{array}{lll}\text { CNDPF } & - & \text { Regional Commission for the Advancement of Women } \\ \text { CNEEP } & - & \text { National Monitoring Committee for the Implementation and Evaluation } \\ \text { CNPF } & - & \text { National Commission for the Advancement of Women } \\ \text { CSA } & - & \text { District Health Center } \\ \text { CSPR } & - & \text { Unit for the Guarantee of Payments and Recovery } \\ \text { DGAE } & - & \text { National Office for Economic Affairs } \\ \text { DGB } & - & \text { National Office for Budgetary Affairs } \\ \text { DGPP } & - & \text { National Office for Programming and Forecasting } \\ \text { DHAB } & - & \text { National Office for Hygiene and Basic Sanitation } \\ \text { DIAG } & - & \text { Department for Gender Integration } \\ \text { DNAEA } & - & \text { National Office for Literacy and Adult Education } \\ \text { DPP } & - & \text { Office for Programming and Forecasting } \\ \text { DRSP } & - & \text { Poverty Reduction Strategy Paper } \\ \text { DSFE } & - & \text { Office of Economic Statistics and Survey } \\ \text { DSS } & - & \text { Office of Social Statistics } \\ \text { EDS I \& II } & - & \text { Population and Health Survey I \& II } \\ \text { ELAM } & - & \text { Sample Household Survey } \\ \text { ETARB } & - & \text { Technical Support Team for Budgetary Reform } \\ \text { FASN } & - & \text { National Solidarity Support Fund } \\ \text { FBCF } & - & \text { Gross Formation of Fixed Capital } \\ \text { FOB } & - & \text { Free on Board } \\ \text { PRGF } & - & \text { Poverty Reduction and Growth Facility } \\ \text { GDP } & - & \text { Gross Domestic Product } \\ \text { HIPIC } & - & \text { Highly Indebted Poor Countries } \\ \text { HIV/AIDS } & - & \text { Human Immuno-Deficiency Virus/Acquired Immune Deficiency Syndrome } \\ \text { ILO } & - & \text { International Labor Organization } \\ \text { IMF } & - & \text { Micro Finance Institution } \\ \text { INSAE } & - & \text { National Institute for Statistics and Economic Analysis } \\ \text { IPH } & - & \text { Human Poverty Index } \\ \text { IRA } & - & \text { Acute Respiratory Infection } \\ \text { MAEP } & - & \text { Ministry of Agriculture, Livestock and Fisheries } \\ \text { MCAT } & - & \text { Ministry of Culture, Small-Scale Industry and Tourism } \\ \text { MCPPD } & - & \text { Ministry of Planning, Forecasting and Development } \\ \text { MDG } & - & \text { Millennium Development Goals } \\ \text { MEHU } & - & \text { Ministry of Environment, Housing and Urban Development } \\ \text { MEMH } & - & \text { Ministry of Energy, Mines and Water Systems } \\ & & \end{array}$




\begin{tabular}{|c|c|c|}
\hline MEPS & - & Ministry of Primary and Secondary Education \\
\hline MESRS & - & Ministry of Higher Education and Scientific Research \\
\hline METFP & - & Ministry of Technical and Vocational Education \\
\hline MFE & - & Ministry of Finance and Economic Planning \\
\hline MFPSS & - & Ministry of Family Affairs, Social Welfare and Solidarity \\
\hline MICPE & - & Ministry of Industry, Trade and Employment \\
\hline MJLDH & - & Ministry of Justice, Legislation and Human Rights \\
\hline MSP & - & Ministry of Health \\
\hline MTPT & - & Ministry of Public Works and Transport \\
\hline $\mathrm{NGO}$ & - & Non-Governmental Organization \\
\hline NITC & - & New Information and Communications Technology \\
\hline OCS & - & Observatory of Social Change \\
\hline OEF & - & Observatory for Employment and Training Projects/Programs \\
\hline OPT & - & Posts and Telecommunications Corporation \\
\hline PAG II & - & Government Program of Action \\
\hline PDC & - & Community Development Plan \\
\hline PEER & - & Equal Equivalent Percentage \\
\hline PERAC & - & Public Expenditure Reform Adjustment Credit \\
\hline PEV & - & Expanded Immunization Program \\
\hline PIP & - & Public Investment Program \\
\hline PNPF & - & National Policy for the Advancement of Women \\
\hline PRS & - & Poverty Reduction Strategy \\
\hline QUIBB & - & Questionnaire on Basic Welfare Indicators \\
\hline RGPH3 & - & Third General Population and Housing Census \\
\hline RNDH & - & National Report on Human Development \\
\hline SBEE & - & National Electricity and Water Company \\
\hline SCALA & - & Aggregate Indicators Collection and Analysis system \\
\hline SFD & - & Decentralized Financial Services \\
\hline SIGFIP & - & Integrated Public Finance Management System \\
\hline SONAPRA & - & National Agricultural Promotion Company \\
\hline $\begin{array}{l}\text { ST/CNSAPAS } \\
\text { Implementatior }\end{array}$ & n- & $\begin{array}{l}\text { Technical Secretariat of the National Structural Adjustment Program } \\
\text { toring Commission }\end{array}$ \\
\hline TAP & - & Rate of Completion of Primary Education \\
\hline TBA & - & Gross Rate of Admission into Primary School \\
\hline TBS & - & Social Performance Chart \\
\hline TEC & - & Common External Tariff \\
\hline TMI & - & Infant Mortality of Children under 5 years/Infant-Child Mortality Rate \\
\hline TOFE & - & Table of State Financial Operations \\
\hline UAC & - & University of Abomey - Calavi \\
\hline UEMOA & - & Union Economique et Monétaire de l'Afrique de l'Oues \\
\hline UNICEF & - & United Nations Children's Fund \\
\hline VAT & - & Value Added Tax \\
\hline WPI & - & Women's Participation Index \\
\hline $\mathrm{ZS}$ & - & Health Zone. \\
\hline
\end{tabular}




\section{LIST OF TABLES}

Table 1.1.1 Trends in Poverty Indices from $1999-2000$ to 2002

Table 1.1.2 Trends in per capita expenditure Gini Index

Table 1.1.3 Breakdown in the variation of poverty indices between 1999-2000 and 2002

Table 1.1.4 Trends in the HPI from 1999 to 2002

Table 1.2.1 Sectoral Growth Rate in \% (basis $100=1985$ )

Table 1.2.2 Convergence Indicator of the inflation rate in 2003

Table 1.2.3 Abstract of the State Financial Operations Table (in billions of CFA Francs)

Table 1.2.4 Trends in the outstanding external public debt (in billions of

CFA Francs)

Table 1.2.5 Abstract of the Balance of Payments (in billions of CFA Francs)

Table 1.2.6 Trends in the Primary Criteria

Table 1.2.7 Trends in the Secondary Criteria

Table 1.3.1 Incidence of Extreme Poverty depending on location

Table 1.3.2 Trends in Gross Rates of Admissions

Table 1.3.3 Gross Rate of Admissions at regional and national level in 2003

Table 1.3.4 Trends in rates of completion of primary education

Table 1.4.1 Trends in average time limit for award of procurement contracts per type of procurement (all ministries inclusive)

Table 1.4.2 Portions of Public Expenditure (capital and recurrent) that are actually made in priority sectors (key ministries)

Table 1.4.3 Share of capital outlays allocated to local governments from the total budget

Table 1.4.4 Trends of Women's Participation Index (WPI)

Table 1.6.1 Gross rate of enrolment in \% of the primary level

Table 1.6.2 Net rate of enrolment at the secondary level

Table 1.6.3 Vocational or academic education: percentage of students per type of education

Table 1.6.4 Number of beneficiaries of bursaries granted under the FASN in 2003

Table 2.1.1 Index of the Implementation of the matrix of Policy measures

Table 2.1.2 Status of Implementation of Policies aimed at consolidating the

Medium term macro-economic framework

Table 2.1.3 Status of Implementation of Policies for the development of Human capital and environmental management

Table 2.1.4 Status of Implementation of health and nutrition policies

Table 2.1.5 Status of Implementation of policies on education

Table 2.1.6 Status of Implementation of policies on Sanitation, energy and environmental management

Table 2.1.7 Status of Implementation of policies on governance and institutional capacity building

Table 2.1.8 Status of Implementation of policies on sustainable employment creation and capacity building of the poor to equip them to participate in decisionmaking and production processes

Table 3.2.1 Action Plan of the Ministries for monitoring and evaluation activities in 2004 2005 


\section{LIST OF DIAGRAMS}

Diagram 1.1.1 Comparative Trends in the actual situation of incidence of poverty as against the Millennium Development Goals approach

Diagram 1.1.2 Comparative Trends of the actual situation of the depth of poverty vis-à-vis the MDGs

Diagram 1.1.3 Comparative Trends of the actual situation of the gravity of poverty vis-à-vis the MDG approach

Diagram 1.1.4 Comparative Trends of the actual situation of the HPI in relation to the MDG targets

Diagram 1.3.1 Trends of maternal mortality per location in Benin from 1992 to 2002.

Diagram 1.3.2 Trends in the prevalence of HIV infection at the antenatal clinics in Benin from 1990 to 2002.

Diagram 1.3.3 Lethality of Malaria per region in Benin in 2002.

Diagram 1.3.4 Supply of potable water per source of supply.

Diagram 1.3.5 Supply of potable water per the source and region

Diagram 1.3.6 Proportion of the population per social standing

Diagram 1.3.7 Availability of latrines in proportion to the population per region

Diagram 1.3.8 Proportions of households with access to public sources of electricity per region 


\section{LIST OF BOXES}

Box 1 Report Preparation Process

Box 2 Poverty index, Class of Foster, et al (1984)

Box 3 Note on the method used in calculating the Women's Participation Index (WPI)

Box 4 Activities undertaken within the framework of improving the PRSP 


\section{EXECUTIVE SUMMARY}

Adopted by the Government in September 2002 and approved by the Bretton Woods Institutions in March 2003, implementation of the 2003-2005 PRSP got off smoothly with the 2000 - 2003 program supported by the International Monetary Fund. During the first year the main focus was to implement the basic scenario. Against this backdrop, the results for new poverty reduction strategy (PRS) were somewhat mixed.

Certainly, some progress was made, notably in public finance management and expenditure, particularly in the ministries that are beneficiaries of the Public Expenditure Reform Adjustment Credit (PERAC). This resulted in the improvement of some social indicators. Unfortunately, these efforts were made at a time when there was a downturn in economic activity, which did not help in achieving projected targets and consequently led the country to adopt a cautious attitude for achieving the Millennium Development Goals (MDGs) by 2015.

As for poverty reduction objectives, the trends observed between 1999 and 2000, and in 2002, do not indicate any significant progress. Generally, the incidence of monetary poverty remained almost static (from $29.3 \%$ in $1999-2000$ to $28.5 \%$ in 2002). Inequality among the poor worsened at the national level mainly as a result of a very significant increase in the gravity index, especially in urban areas.

The gap between the MDG poverty line and trends recorded in Benin is still considerable, especially in terms of the depth and gravity of poverty. If this trend were to continue, the goal of cutting poverty by half by 2015 would be difficult to achieve.

As for non-monetary poverty, a positive trend in the human poverty index is perceptible (the HPI 1 slides down from $51.4 \%$ in 1999 and $49.9 \%$ in 2001 to $48.9 \%$ in 2002) because of efforts made by the authorities in maternal and child health, and an increase in socio-community infrastructure investment (health centers, district hospitals, boreholes, etc.). However, as compared to the MDG target, we note that the HPI 1 of 2002 is 3.79 points above the expected $45.1 \%$. So, as far as this indicator is concerned, Benin has to redouble its efforts to get back on track to achieve targets set for 2015.

Economic activity maintained almost the same level of growth as in 2002. The growth rate stood at $3.9 \%$ but still lagged behind the PRS goals due to a bad 2002-2003 agricultural season and under performance in the secondary sector. In fact, the primary sector contributed only $0.9 \%$ to the GDP growth just as in 2002. Apart from the inflation rate, which stood at $1.5 \%$, the situation is not encouraging. Certain economic goals set in 2003 at the macro and sectoral levels were not reached.

However, despite a worsening budget deficit, public finance management remained sound. In fact, the overall deficit excluding grants rose to $4.6 \%$ of GDP, indicating a downward trend as compared to the annual target of $4.0 \%$. The "external debt service/fiscal revenue" ratio stood at $4.4 \%$ in 2003 as against $9.4 \%$ in 2002. Similarly, the outstanding balance of trade excluding reexports improved between 2002 and 2003. Excluding re-exports, the balance of trade deficit came to CFA francs 195.2 billion in 2003, down from 200.0 billion in 2002. Consequently, the 
balance of trade deficit widened between 2002 and 2003 from CFA francs 108.9 billion (5.1\% of GDP) to 127.1 billion (or 6.1\% in 2003). Excluding official transfers (grants), the current balance deficit reached $8.2 \%$ of GDP in 2003 versus $8.3 \%$ in 2002 .

Despite growth in national wealth, there still seems to be a problem with wealth redistribution to stem the tide of poverty in Benin. The breakdown of variations in poverty indices between 1999 and 2002, shows that the increase in the depth and gravity of monetary poverty at the national level is chiefly due to a lack of redistribution $(0.09 \%$ for $\mathrm{P} 1$ and $0.06 \%$ for $\mathrm{P} 2)$ on growth $(-0.06$ for P1 and -0.03 for P2). This situation calls for priority attention to economic policy measures that ease poverty and, in particular, a focus on stronger economic growth in sectors where the poor are actively involved.

Progress on good governance and institutional capacity building was uneven. Thus, the rate of budgetary implementation of recurrent expenditure, excluding salaries of the PERAC ministries, improved and stood at an average of $98.8 \%$ between 2001 and 2003. However, this performance was marked by wide sectoral disparities. Compared to the rate of budgetary implementation of recurrent expenditure excluding salaries, the average rate of budgetary execution of capital expenditure of the PERAC ministries from 2001 to 2003 was lower (7.1\%). This resulted in low use of credit facilities. Both the Benin government and its development partners (whose contributions still account for $59.7 \%$ of the country's capital budget) are to blame. The major bottlenecks that impede the execution of projects and, consequently, limit the use of credit lines are often linked to:

(i) The delay in the release of funds and in signing agreements on the management of projects;

(ii) Inadequate knowledge of the new public expenditure procedures as well as those of the Integrated System for Public Finance Management (SIGFIP);

(iii) The multiplicity of disbursement procedures by donors;

(iv) Relatively inadequate capacities of some project managers; and

(v) National procedures for disbursement of investment funds that delay the execution of certain projects social infrastructure project.

It must be noted that in 2003, the projected timeframe targets for public procurement were not attained. Greater efforts are needed to speed up public payments. However, that the PERAC ministries registered a net improvement in this regard. In addition, the share of public expenditure that went effectively into priority sectors increased between 2001 and 2002. In 2003, it remained around $36 \%$ and was expected to move upwards with the hope of reducing poverty. As for budgetary transfers by the State to local governments, we also saw delays in achieving selected targets under the PRSP. In fact, in 2003, less than $1 \%$ of budgetary credits were allocated to local governments. This is mainly due to the fact that decentralization is at its early stages in Benin and bedeviled with problems, including a dearth of qualified personnel and inadequate capacities at the local level.

The women's participation index (WPI) improved from 0.281 in 2000 to 0.315 in 2001, to 0.348 in 2002 , and fell back a bit to 0.336 in 2003 perhaps the result of a drop in the number of ministerial portfolios held by women. In any case, the level of participation and decision-making power of women in the Benin economy increased steadily within the period. 
The few indicators developed to evaluate the level of implementation of certain actions under the fourth strategic axis of the PRSP suggest that efforts still need to be made to improve collaboration and the capacity of the poor in the decision-making and production processes. Indeed, no indicators were expected by the PRSP. Only 8 out of the 77 districts currently have a community development plan; the rate of penetration of decentralized financial services is still low $(26.3 \%$ according to the data presented by the Micro-finance Unit). Moreover, in all the 77 districts of the country, there are many towns and villages that are inaccessible for a greater part of the year.

With regard to gender, a lot of effort has been made on the legal front to create awareness and underscore the importance of gender in national development. Important legal measures were taken in 2001 and 2003 in keeping with the monitoring-evaluation of the Beijing Plan of action. Thus, steps to improve school enrollment were taken, although wide disparities still persist between girls and boys at the primary, secondary and tertiary levels. Moreover, the government committed itself to promoting women's access to land, especially in rural communities and to revising the current land laws.

The condition of children was a major concern for the government in 2003, particularly child trafficking. In addition, educational opportunities for the development of exploited children as well as functional literacy were created in 12 social development centers across the country.

An evaluation of the PRSP matrix of policy measures indicates that, all-in-all, about half $(50.3 \%)$ of the policies under the PRSP were implemented in 2003. This sub par performance is due mainly to delays in implementing policies that strengthen good governance and institutional capacity building. The level of implementation under this axis was $27.3 \%$. Serious efforts are also needed to achieve an average level of implementation for policies that strengthen the mediumterm macro-economic framework. One of the reasons for weakness in this area was a lack of institutional "ownership" of the PRSP, leading to a stalemate in implementing structural reforms, especially privatization and expediting actions on administrative reforms. Of the four main strategic axis under the PRSP - sustainable employment creation and capacity building for the poor to participate in decision-making and production processes -- scored the highest with more than two-thirds of set policy objectives being implemented. The "Social Welfare and Advancement of Women" sub-axis average was 79\%, and the "Micro-finance Development" axis, $90 \%$. This underscores the will of government to give priority attention to women's advancement. What remains to be seen is whether policies will bring about desired changes in attitudes and mentalities -- on the part of both men and women - that favor better integration of women into the development process.

The institutional framework for drawing up the Poverty Reduction Strategy Paper (PRSP) and the first year strategy implementation is regulated by decree No. $2000-535$ of November $2^{\text {nd }}$ 2000, specifying the prerogatives, composition and running of the National Commission for Development and the Fight Against Poverty (CNDLP). This framework did not change much in 2003. Efforts were taken to make various anti-poverty institutions operational. In 2003, Departmental Monitoring Committees from the PRSP were added to the framework. In March 2003, a workshop was organized with the goal of revamping the Observatory of Social Change, which is the technical institution responsible for implementing the PRSP monitoring and evaluation mechanisms. 
A new institutional framework, the National Commission for Development and the Fight Against Poverty has been in place since 21 February 2004. The framework will regulate activities in 2004 and 2005. To avoid failure, the relevant inter-ministerial directives must spell out in clear terms the responsibilities of the Observatory of Social Change's Permanent Secretariat.

To ensure successful PRSP implementation in 2004 and 2005, a number of recommendations were made, including:

(i) dissemination of the PRSP for prompt implementation of the matrix of policy measures;

(ii) extension of the practices of preparing program budgets to all the ministries;

(iii) capacity building in institutions responsible for collecting and processing primary and secondary data to ensure sustained implementation and prompt information updates; and

(iv) pursuit of economic reforms that create wealth creation with a view to ensuring more equitable distribution.

To achieve the overall and sectoral targets set by the PRSP, additional funds must be mobilized for implementing the final phase. It will also be important to start reflecting on the next PRSP, including a plan to evaluate implementation. 


\section{INTRODUCTION}

Despite 10 years of structural adjustment programs, poverty in Benin persists. Against this backdrop, the government drew up a Poverty Reduction Strategy Paper (PRSP) as far back as the end of the 1990s. More recently, Benin was declared eligible for the Enhanced HIPC Initiative (Highly Indebted Poor Countries) by the Bretton Woods Institutions.

The final version of the 2003-2005 PRSP was officially adopted by the Cabinet in September 2002 and approved by the Executive Boards of the Bretton Woods Institutions in March 2003, thereby enabling Benin to reach the completion point of the Enhanced HIPC. The PRSP is now the overall strategic inter-sectoral reference document in Benin. It seeks to enhance coordination among national stakeholders and development partners, based on the technical and institutional capacities of the government.

Based on analysis, four strategic axes for poverty reduction were selected:

(i) strengthening of the medium-term macro-economic framework;

(ii) developing human capital and environmental management;

(iii) strengthening governance and institutional capacities;

(iv) promoting sustainable employment and strengthening the capacity of the poor to participate in the decision-making and production processes.

Implementation of the poverty reduction strategy began in 2003 . The 2003 budget is in line with the basic PRSP budget scenario and shows the commitment of government to the priority sectors as part of the measures to stem poverty.

While extending the economic strategy formulated in 2002, the new directions are based on the following priority objectives:

- strengthening macro-economic stability;

- improving basic social services;

- implementing the decentralization of state power;

- strengthening income -generating activities for the poor.

The 2003 report is the only document on the status of PRSP implementation. At the time the 2003-2005 PRSP was adopted, it was envisaged that it would be updated annually. It will also be thoroughly revised every three years.

This report's general objective is to analyze progress made in 2003 regarding poverty reduction, the implementation of the PRSP and introduction of monitoring and evaluation mechanisms for this process.

The specific objectives are as follows:

1. Trends in outcome and impact indicators of the PRSP in 2003; assess possible gaps between the targets set for 2003 and the levels observed; and analyze the (exogenous and/or endogenous) factors behind the trends observed; 
2. Give an account of the status of implementation of the measures matrix contained in Appendix 12 of the 2003-2005 PRSP; analyze the reasons for possible delays; and propose corrective measures where necessary;

3. Give an account on the implementation status of the monitoring and evaluation mechanisms of the PRSP; analyze possible weaknesses; and propose corrective measures where necessary;

4. Contribute to a national policy dialogue both at the central level (Parliament, development partners, etc.) and at the provincial and community level. This dialogue will also generally involve the entire population.

In order to achieve these objectives, three groups of indicators have been retained:

1. Outcome and impact indicators for which development targets are set;

2. Output indicators that facilitate the understanding of trends in results and impacts observed;

3. Indicators for implementing the matrix of PRSP measures, particularly input, activity and output indicators.

The report is divided into three parts:

1. The first is the analysis of 2003 poverty trends, the level of achievement of development targets, the causes of poor performance and the impact of policies and programs implemented. This part hinges on the overall poverty reduction objectives. It is also based on the strategic PRSP axis. It involves the analysis of results and impact indicators retained as well as the evaluation of the complementary sectoral indicators;

2. The second part deals with the status of implementation of the matrix of PRSP measures, the possible delays, causes and proposed corrective measures. It provides an analysis of implementation indicators for each measure under the relevant PRSP axis. The section on corrective measures proposes changes in policies and programs to improve implementation;

3. Finally, the third part deals with the introduction of monitoring and evaluation mechanisms both at the technical and institutional levels as well as a PRSP plan of action to improve these mechanisms. 


\section{REPORT PREPARATION PROCESS}

The 2003 Report is a national report. It was drawn up by a national team made up of top national officers and experts from the Permanent Secretariat of the National Commission for Development and the Fight against Poverty (CNDLP/PS) and top officials from the Department of Planning and Projections (DPP of the sector ministries concerned). This team is enjoying international technical assistance, which is first and foremost contributing to the improvement in methodology and strengthening of national capacities.

One should be realistic about one's expectations from the 2003 Report. First, it is not a final evaluation of the PRSP, which will actually be done at the end of the three-year cycle. Secondly, it does not meet all the monitoring \&.evaluation requirements. Among others, it is not a substitute for the monitoring and evaluation reports on the PRSC -1 , budgetary assistance, the implementation of the Medium Term Expenditure Framework (CDMT), and the sectoral strategies and plans of action. However, the Government expects that these issues would be clearly stated as part of the report on the status of implementation of the PRSP in the annual review.

The CNDLP/PS is tasked with the publication of the Report. To ensure efficiency and coordination, the Report shall be the sole report to be published by the CNDLP/PS to serve as a reference document for the annual review. The process of preparation and validation of the Report involves the collaboration and contribution of (i) all the functional units of the Observatory of Social Change (OCS); (ii) the sector ministries involved in the implementation of the PRS; and (iii) civil society and the private sector both at the national and departmental levels. The report is written by Report Thematic Groups (GTRs). In all, nine (9) GTRs were formed and these work under the supervision of a Report Drafting Committee (CRR).

The formation of each group depends on the contents of the various sections of the Report. Each GTR includes a lead structure and other ancillary structures to ensure an intersectoral vision and a concerted involvement of the national stakeholders. It is made up of members of the DPPs of the concerned ministries, functional units of the OCS and civil society and private sector representatives. As much as possible, this collaboration is carried out in strict compliance with the very tight schedule. The leader of each GTR is ultimately responsible for the drafting of the sections and sub-sections entrusted to the group. However, in the case of the 2003 report, resource persons who were well versed in the issues handled the preliminary GTR work because of time constraints. The members of the GTR validated the preliminary work done by these resource persons. From this standpoint, the work becomes the property of the GTR.

The CRR is under the chairmanship of the Permanent Secretariat (PS) of the CNDLP and made up of the following members.

- National Experts supporting the CNDLP/PS;

- Top management staff of the CNDLP/PS;

- A representative of the DGPP;

- A representative of the CAPE;

- A representative of the INSAE;

- A representative of the DGB;

- A representative of the DGAE;

- A civil society representative, and

- A private sector representative

The CRR has the following terms of reference;

- $\quad$ Set out the terms of reference of the GTRs;

- $\quad$ Support the GTRs, depending on their needs, in drafting their documents in order to ensure conformity with the TDR as well as the scope and depth of the analyses;

- $\quad$ Prepare the executive summary of the Report;

As part of the work on the Report, the CNDLP/PS was mandated to:

- Validate the preliminary version of the Report;

- Organize national and departmental consultative and validation Workshops for the draft version of the report;

- Submit the final version to the CNDLP for final validation and for onward transmission to the Government.

The annual review cycle approved in the Guide for the monitoring and evaluation of the implementation of the PRSP drawn up for the purpose, scheduled the annual review for the month of June. This supposes that the preparation, validation and adoption of the report by the Government through the CNDLP inter-ministerial Committee should be done in May at the latest. However, owing to reasons beyond the control of the CNDLP/PS, this cycle could not be adhered to for the drafting of the first report. 


\section{ANALYSIS OF POVERTY TRENDS AND ECONOMIC POLICIES IMPLEMENTED IN 2003}

The trend analysis was done by using a list of 33 indicators (Appendix 1). They are classified as overall poverty reduction objectives in accordance with the four major PRSP axes.

\subsection{Poverty trends and progression relation to the overall PRSP objectives in 2003}

The trends in poverty and its progression in relation to the overall PRSP objectives in 2003 have been analyzed from a monetary rather than a non-monetary point of view with the following indicators:

$$
\begin{aligned}
& \text { - } \quad \text { incidence of monetary poverty; and } \\
& \text { - } \quad \text { human poverty index (HPI - 1) }
\end{aligned}
$$

According to the overall PRSP objectives, implementation of the poverty reduction strategy should reduce the incidence of poverty from $28.5 \%$ in 2002 to $26.8 \%$ in 2003 at the national level. This rate is expected to be $29.9 \%$ in the rural areas and $21.1 \%$ in the urban areas. It is important to stress that available data do not portray the real poverty situation for 2003. Indeed, 2003 was not covered by the standard surveys for poverty measurement. The QUIBB survey planned for 2003-2004 in the PRSP improvement scheme could not be carried out.

The trend analysis covers 1999 and 2000 (2003-2005 basic data for the PRSP), and 2003 (data of the 2003 QUIBB $^{1}$ survey). Data available for this period show stagnation in the level of monetary poverty and a slight reduction in non-monetary poverty.

\subsubsection{Monetary poverty ${ }^{2}$}

Monetary Poverty in Benin is measured by the level of household expenditure with reference to a poverty threshold. At the national level, the incidence of monetary poverty (P0) fell slightly from $29.3 \%$ in $1999-2000$ to $28.5 \%$ in 2002 . One should qualify this slight relative reduction in monetary poverty. Indeed, it was observed that there was a substantial increase in the absolute number of poor people between 2000 and 2002 because of the growth in population that was noticed after the general population census in 2002.

Similarly, the poverty depth index (P1) went up slightly from 0.08 in 1999-2000 to 0.11 in 2002 (Table 1.1.1). However, the data show that the poverty deficit (P1/P0) increased significantly

\footnotetext{
${ }^{1}$ Based on 2003 QUIBB survey data and not the outcomes of these same data contained in the Poverty Paper of Benin.

2 As a result of the analysis of poverty trends, the 2003 QUIBB survey data were processed and analysed by the National Institute of Statistics and Economic Analysis (INSAE) in the same way as it was done for the ECVR2 and ELAM9 surveys. The adult scales of equivalence used in the two types of survey are the same but different from those used for the outcomes contained in the Poverty Paper of Benin.
} 
from $28.7 \%$ of the threshold in $1999-12000$ to $38.2 \%$ in 2002 . Inequality among the poor worsened at the national level. This situation is particularly due to the sharp rise in the gravity index, especially in the urban areas.

Table 1.1.1: Trends in Poverty Indices from 1999-2000 to 2002

\begin{tabular}{|c|c|c|c|c|c|c|c|c|c|}
\hline \multirow[t]{2}{*}{ Area } & \multicolumn{3}{|c|}{$1999-2000$} & \multicolumn{3}{|c|}{2002} & \multicolumn{3}{|c|}{$\begin{array}{c}\text { Annual rate of change } \\
(\%)\end{array}$} \\
\hline & P0 & P1 & P2 & P0 & P1 & P2 & P0 & P1 & P2 \\
\hline Urban & $\begin{array}{r}0.233 \\
(0.020)\end{array}$ & $\begin{array}{r}0.069 \\
(0.012)\end{array}$ & $\begin{array}{r}0.030 \\
(0.008)\end{array}$ & $\begin{array}{r}0.236 \\
(0.009)\end{array}$ & $\begin{array}{r}0.107 \\
(0.005)\end{array}$ & $\begin{array}{r}0.069 \\
(0.004)\end{array}$ & 0.64 & $24.5^{*}$ & $51.7 *$ \\
\hline Rural & $\begin{array}{r}0.330 \\
(0.035)\end{array}$ & $\begin{array}{r}0.094 \\
(0.022)\end{array}$ & $\begin{array}{r}0.039 \\
(0.015)\end{array}$ & $\begin{array}{r}0.316 \\
(0.008)\end{array}$ & $\begin{array}{r}0.110 \\
(0.004)\end{array}$ & $\begin{array}{r}0.058 \\
(0.003)\end{array}$ & -2.08 & 8.3 & 22.6 \\
\hline Total & $\begin{array}{r}0.293 \\
(0.023) \\
\end{array}$ & $\begin{array}{r}0.084 \\
(0.014) \\
\end{array}$ & $\begin{array}{r}0.035 \\
(0.009) \\
\end{array}$ & $\begin{array}{r}0.285 \\
(0.006) \\
\end{array}$ & $\begin{array}{r}0.109 \\
(0.003) \\
\end{array}$ & $\begin{array}{r}0.062 \\
(0.002) \\
\end{array}$ & -1.34 & 13.7 & $32.5^{*}$ \\
\hline
\end{tabular}

Source: INSAE, 2003 QUIBB Survey; $(*)$ Significant at $5 \%$

$\mathrm{PO}=$ Incidence of Poverty; $\mathrm{P} 1=$ depth; $\mathrm{P} 2$ = gravity of poverty

In the rural areas, the incidence of monetary poverty has not changed significantly since 1999 . In the urban areas, however, although the size of the poor has remained statistically stable, the deficit and gravity of poverty have risen sharply.

\section{Poverty Index, Class of Foster et al. (1984).}

BOX NO.2

Let $\mathrm{P}$ be the class of poverty indicators that can be factorized. If $\mathrm{f}(\mathrm{x})$ is the probability density of standard of living indicator $\mathrm{x}$ (expenditure or income per adult equivalent, for example), then $\mathrm{P}$ represents poverty line $\mathrm{Z}$

$$
\mathbf{P}=\int_{0}^{z} \theta(x, z) f(x) d x
$$

Where $\theta(x, z)$ is a decreasing function in $\mathrm{x}$, an increasing function in $\mathrm{Z}$ and homogeneous at 0 degrees in $\mathrm{X}$ and Z. assuming that poverty indicator $\mathrm{P}$ is part of the class of indicators proposed by Foster et al. (1984), we shall have

$P_{\alpha}=\int_{0}^{z}(1-x / z)^{\alpha} f(x) d x$

on an $\mathrm{n}-$ sample $\left(\mathbf{x}_{1}, \mathbf{x}_{2}, \ldots ., \mathbf{x}_{\mathbf{n}}\right)$, the index Pa calculated by $P_{\alpha}=\frac{1}{n} \sum_{i=1}^{n}\left(1-x_{i} / z\right)^{\alpha} 1\left(x_{i}<z\right)$

If a $=0, \mathrm{P} 0$ is the incidence of poverty;

That is the proportion of the poor ;

If $\mathrm{a}=1$, then $\mathrm{P} 1=\mathrm{P} 0 \mathrm{I}$ where I refers to the intensity or depth of poverty;

If $\mathrm{a}=2, \mathrm{P} 2$ is the index of the gravity of poverty; it is used to measure the level of inequality among the poor.

Source: UNDP/DANIDA - SS/DPP/MAEP/INSAE, ECVR2, 1999-2000

With regard to the Millennium Development Goals (MDGs), the goal of MDG 1 is to reduce by half the number of people living below the poverty line. However, the poverty incidence curve is above the desired trend. Diagrams 1.1.1, 1.1.2, 1.1.3, and Table 1.1.2 show that even if the gaps are narrowed in terms of the incidence of poverty, they become much wider when we consider 
depth and gravity. If this trend continues, Benin will not be able to reduce by half the incidence of monetary poverty by 2015 .

Diagram 1.1.1: Comparative Trends in the actual situation of the incidence of poverty in relation with the MDG targets.

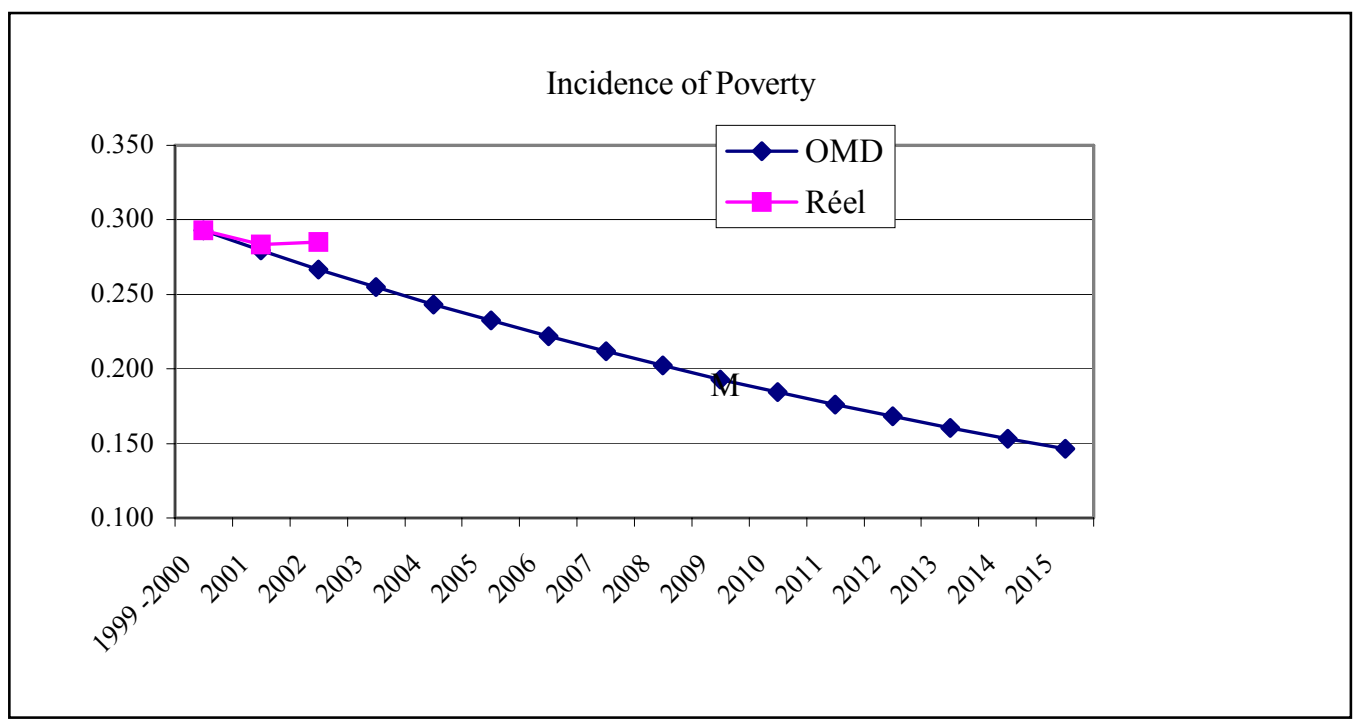

Diagram 1.1.2: Comparative Trends in the actual situation of the depth of poverty in relation to the MDG target

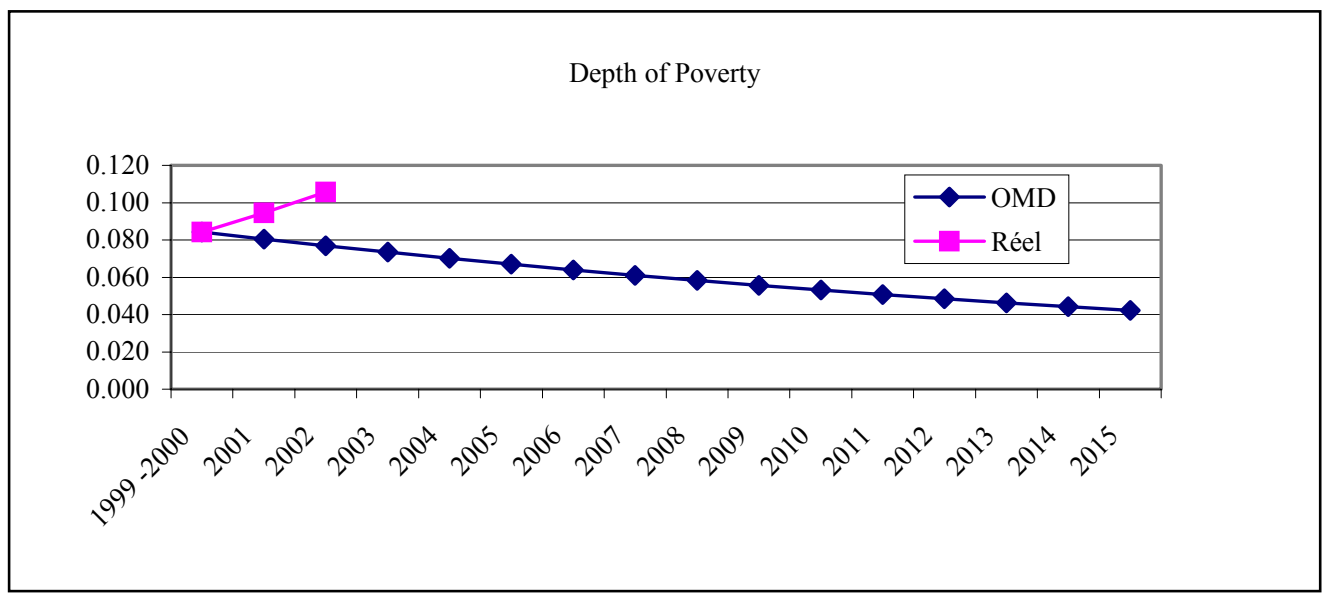

Source: 2003 QUIBB, INSAE 
Diagram 1.1.3: Comparative Trends in the actual situation of the gravity of poverty in relation the MDG target

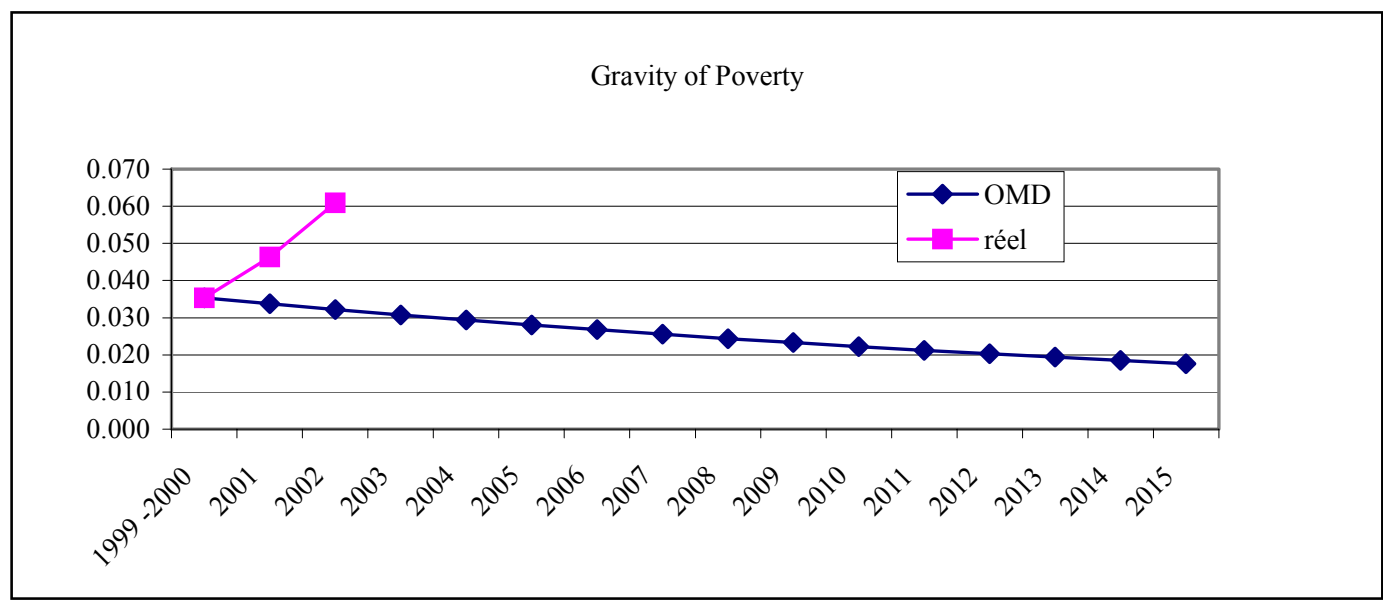

\section{Source: 2003 QUIBB, INSAE}

We should be interested in trends in certain expenditure features, particularly average expenditures and the inequalities measured by the Gini index.

At the national level, per capita average expenditure increased by $10.8 \%$ from CFA 148,164 in 1999-2000 to CFA 164,212. This average does not show the disparities for individual communities. In the urban areas, the actual per capita expenditure dropped by $10.7 \%$ from CFA 234,326 TO CFA 209,171. However, in rural areas, it increased by $69.1 \%$ from CFA 73,325 in 1999 to CFA 123,980 (ELAM 9; QUIBB).

At the same time, we see a reduction in per capita expenditure inequalities at the national level and in the urban areas. The Gini index dropped from 0.47 (0.51) in 1999-2000 to $0.45(0.42)$ in 2002. Conversely, the increase in per capita expenditure for the rural areas gave rise to an increase in the inequalities, with the Gini index increasing from 0.30 to 0.34 (Table 1.1.2).

Table 1.1.2: Trends in the Gini index for per capita expenditures

\begin{tabular}{lccc}
\hline \hline & Benin & Urban & Rural \\
\hline $1999-2000$ & 0.506 & 0.477 & 0.300 \\
& $(0.009)$ & $(0.010)$ & $(0.006)$ \\
2002 & 0.415 & 0.451 & 0.339 \\
& $(0.005)$ & $(0.009)$ & $(0.005)$ \\
\hline
\end{tabular}

Source: 2003 QUIBB, INSAE

Growth and redistribution generally seem to have had little impact on the incidence of poverty. The positive effect of growth (-15.6 points at the national level) is more noticeable in rural areas (28.5 points). In urban areas, the favorable effect of redistribution (-4.8 points), which led to the decrease in the inequality of per capita expenditure, was not enough to reduce the unfavorable 
impact of growth (5.1 points). This has given rise to a slight increase in the incidence of poverty (0.3 points).

The increase in the depth and gravity of poverty at the national level is mainly due to the unfavorable effect of redistribution $(0.09$ for $\mathrm{P} 1$ and 0.06 for $\mathrm{P} 2)$ in relation to that of growth (0.06 for $\mathrm{P} 1$ and -0.03 for $\mathrm{P} 2$ ) [Table 1.1.3].

Table 1.1.3: Breakdown of the variation of poverty indices between 1999-2000 and 2002

\begin{tabular}{lccccccccccc}
\hline Place of & \multicolumn{3}{c}{ Variation } & & \multicolumn{3}{c}{ Growth } & & \multicolumn{3}{c}{ Redistribution } \\
\cline { 2 - 3 } \cline { 9 - 11 } Abode & P0 & P1 & P2 & & P0 & P1 & P2 & & P0 & P1 & P2 \\
\hline Urban & $0.003^{*}$ & 0.038 & 0.039 & & 0.051 & 0.020 & 0.012 & & -0.048 & 0.018 & 0.027 \\
& 0.022 & 0.013 & 0.009 & & 0.013 & 0.007 & 0.005 & & 0.013 & 0.007 & 0.005 \\
Rural & $-0.014^{*}$ & 0.016 & 0.019 & & -0.285 & -0.077 & -0.037 & & 0.188 & 0.093 & 0.056 \\
& 0.035 & 0.022 & 0.015 & & 0.018 & 0.011 & 0.008 & & 0.019 & 0.011 & 0.008 \\
Total & $-0.008^{*}$ & 0.025 & 0.027 & & -0.156 & -0.064 & -0.033 & & 0.148 & 0.088 & 0.060 \\
& 0.023 & 0.015 & 0.010 & & 0.012 & 0.008 & 0.005 & & 0.013 & 0.008 & 0.005 \\
\hline
\end{tabular}

Source: 2003 QUIBB, INSAE; (*) insignificant at 5\%

In spite of the favorable trends in the national economy, with an average GDP growth rate of $5.25 \%(2000-2002)$ and an increase in household consumption, the incidence of poverty remained quite stable during the period. This seems to indicate a structural rather than economic poverty ${ }^{3}$. Although per capita household consumption increased by 6.5\% from 1999 to 2002 (CFA 94,667 in 1999 and CFA 100,849 in 2002) and is the main source of growth having accounted for up to $75.5 \%$ in 1999 and $92.5 \%$ in 2002, respectively, the incidence of poverty remains high.

At the sectoral level, it was the tertiary and secondary sectors that accounted for most of the growth in recent years (44.6\% in 2000 and $45.5 \%$ in 2002). These sectors are predominantly in the urban areas. This shows that urban households have undoubtedly experienced more growth than those in the rural areas. In reality, however this is not the case because Table 1.1.3 shows that the growth component is higher than that for redistribution, having an unfavorable impact on poverty, whatever index is considered. In the rural areas, the growth component was above the redistribution component.

\subsubsection{Non-Monetary poverty}

Non-monetary poverty is analyzed by using the Human Poverty Index (HPI). Human poverty is defined as a set of deprivations: low life expectancy, poor health, lack of access to education, poor living conditions, inability to take part in community activities, etc. These are measured by the Human Poverty Index (HPI $\left.{ }_{1}\right)$. It is a composite index calculated as a weighted average of: 1) the probability of death before the age of 40;2) adult illiteracy rate; and 3) the arithmetic average of the percentage of the population deprived of potable water and the percentage of children under five years of age.

\footnotetext{
${ }^{3}$ With regard to time, we can think of structural poverty but in reality, the economic situation is cyclical because for 8 years now, there has been inadequate and stagnant growth of about 5\%; if we are able to go beyond this stage and the economy does not generate more employment, opportunities and income, we can rightly conclude that there is structural poverty
} 
Table 1.1.4: Trends in the HPI1 over the period 1999-2002

Probability at birth Adult Illiteracy Rate Percentage of to die before age 40

the population

deprived of

Percentage of

$\mathrm{HPI}_{1}$

children under

5 years who are

potable water underweight

\begin{tabular}{llllll}
\hline & & & & & \\
1999 & 0.297 & 0.691 & 0.451 & 0.29 & 0.514 \\
2001 & 0.297 & 0.679 & 0.411 & 0.23 & 0.499 \\
2002 & 0.243 & 0.674 & 0.392 & 0.23 & 0.489 \\
\hline
\end{tabular}

Source : RGPH3, RGPH2 and EDS1 and 2

At the national level, the human poverty index is $48.9 \%$. It dropped from $51.4 \%$ in 1999 and $49.9 \%$ in 2001 . The significant reduction of the human poverty index can be attributed to efforts made in the area of maternal and child health, on the one hand, and to the increase in investments in socio-community infrastructure on the other hand (health centers, district hospitals: Benin reached an acceptable coverage rate of $82 \%$ for front-line health infrastructure, drilling of boreholes). Consequently, the general health status of people is improving: the probability of death before 40 as well as the percentage of underweight children under 5 years are decreasing; and life expectancy at birth is improving, increasing from 54.2 years in 1992 to 59.2 years in 2002.

With regard to the MGDs, the 2002 HPI $1_{1}$ remains higher than the expected outcomes particularly as a result of the high rate of illiteracy among adults and the large percentage of the population deprived of potable water [Diagram 1.1.4].

\section{Diagram 1.1.4: Comparative Trends in the actual level of HPI in relation the MDG targets.}

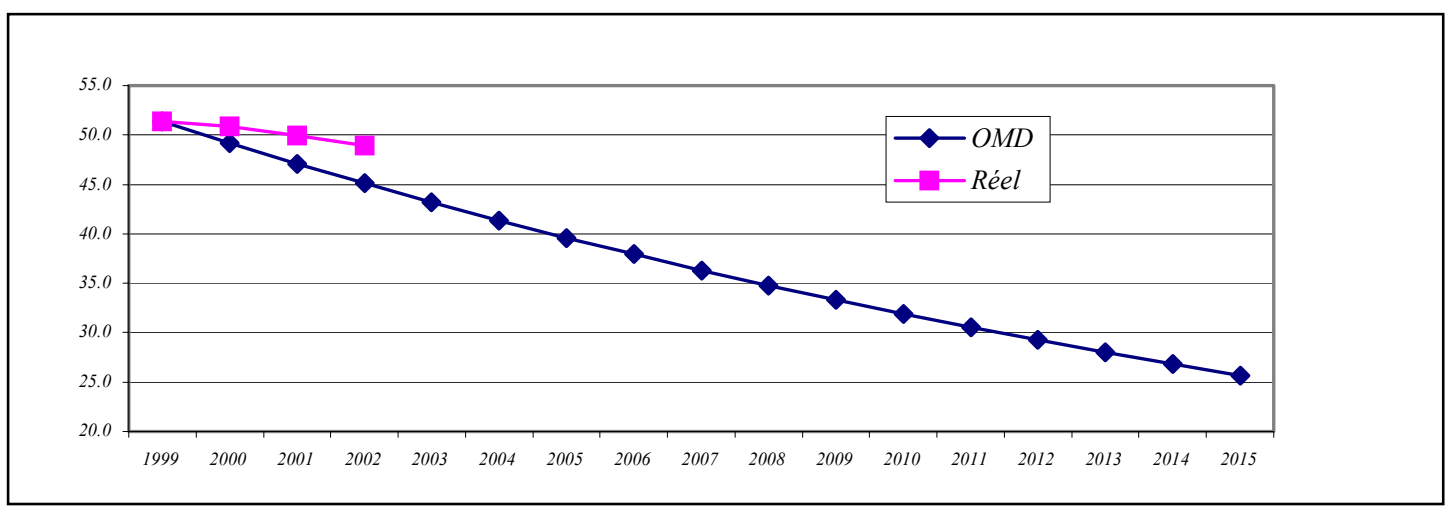

Source: 2003 QUIBB, INSAE

\subsection{TRENDS IN THE ECONOMIC SITUATION AT THE MACRO AND SECTORAL LEVELS AND ANALYSIS OF POLICIES IMPLEMENTED IN 2003}

The priority objective of the first axis of the poverty reduction strategy is the consolidation of macro-economic stability. The objectives of the approved macro-economic policy program under the 2003 poverty reduction and growth facility reflect the basic macro-economic framework of the Poverty Reduction Strategy Paper (PRSP). These objectives aim at: 
1. economic growth rate of about $7 \%$ per annum;

2. inflation rate of below $3 \%$, in keeping with the UEMOA convergence criterion;

3. current external deficit, including current official transfers, below 7\% of GDP.

To hit these targets, the government agreed to implement a monetary and fiscal policy that will ensure financial stability. In this context, the overall deficit target of the State (on orders basis and excluding grants) remains fixed at $4.0 \%$ of GDP.

\subsubsection{Trends in Macro-economic and sectoral situation}

In 2003, Benin's economic context was characterized by:

- The deepening of structural reforms as part of the implementation of the economic program supported by the PRGF, particularly streamlining the financial sector;

- Reaching the completion point of the HIPC initiative which will facilitate the mobilization of the necessary external resources for the implementation of the poverty reduction program;

- The continuing modernization of economic infrastructure, particularly transport and communications, through the major works initiated by the government and private operators;

- The willingness of Benin authorities to adhere to the commitments arising out of the UEMOA Convergence, Stability, Growth and Solidarity Pact, and

- The uncertainties relating to external shocks, particularly the trends in price of crude oil and cotton, the major export commodity of Benin, which have disrupted the country's overall macro-economic performance.

In order to assess the effects of government policies on the macro-economic and sectoral environment, six main indicators were analyzed:

- Real economic growth rate

- Inflation rate

- Real per capita (GDP growth rate)

- Overall deficit (on orders basis and excluding grants) as a percentage of GDP

- Trade balance (excluding re-export commodities) as percentage of GDP

- Debt servicing provision as a percentage of exports.

\subsubsection{Real Economic growth rate}

After some ten years of relatively robust growth, Benin's economic growth experienced a downward trend between 2000 and 2003. In essence, the slowdown is the result of a low level of agricultural diversification, inadequate development of the industrial sector and delays in making certain structural reforms.

In 2003, this situation was worsened by prohibitive measures taken by Nigeria against products re-exported from Benin. This, together with the lack of competitiveness of the Port of Cotonou and the Beninese corridor, reduced tax revenues and economic activity during the year. In addition, the cotton sector, which is the main export commodity, faced serious organizational problems, leading to a reduced production. 
At the end of the 2002 - 2003 crop year, seed cotton production was 337,312 tons versus the projected 350,000 tons. This level of production compares with 411,794 tons produced during the 2001-2002 season, an 18.1\% drop. This under-performance by the sector is due to problems encountered during the season. These problems particularly stem from the following:

(i) Delays in transporting cotton from the factories;

(ii) Unofficial purchases of seed cotton outside the authorized network (CSPR); and

(iii) Production cutbacks and a delay in the start of the 2002-2003 season. The main causes for this delay were:

- The slow pace of talks to determine the producer price of seed cotton and the transfer price to seed crushers;

- A delay on the part of the ginneries to make an advance payment of $40 \%$ of the total amount of purchases required by the Unit for the Guarantee of Payments and Recovery (CSPR) before any delivery of seed cotton is effected; and

- Finally, problems of coordination among the various actors.

Apart from cotton, there was a reduction in main food crop production because of excessive rainfall that caused the harvests to rot.

In the secondary sector, a certain level of under-performance was recorded by the textile industry and other manufacturing industries.

Table 1.2.1: Rate of Sectoral Growth in \% (basis $100=1985)$

\begin{tabular}{|c|c|c|c|c|}
\hline & 2000 & \multicolumn{2}{|c|}{2002002} & $\begin{array}{l}200 \\
3\end{array}$ \\
\hline Primary Sector & 4.5 & 6.4 & 2.4 & 2.2 \\
\hline Including agriculture & 4.9 & 7.5 & 1.6 & 2.2 \\
\hline Secondary Sector & 8.6 & 9.4 & 7.6 & 2.7 \\
\hline $\begin{array}{l}\text { Including manufacturing } \\
\text { industries }\end{array}$ & 8.8 & 9.1 & 6.8 & 0.5 \\
\hline Tertiary Sector & 4.1 & 6.0 & 5.4 & 6.0 \\
\hline $\begin{array}{l}\text { Including transport and } \\
\text { telecommunications }\end{array}$ & 4.0 & 5.6 & 5.5 & 5.5 \\
\hline Including trade & 3.9 & 6.5 & 6.6 & 6.5 \\
\hline Total GDP & 4.9 & 6.2 & 4.4 & 3.9 \\
\hline
\end{tabular}

Source: DSEE/INSAE, September 2003 - GDP method with prices comparable to UEMOA.

In 2003, the primary sector accounted for $0.9 \%$ of GDP growth as against $0.9 \%$ in 2002 . The tertiary sector made a reasonable contribution of $2.6 \%$ in 2003 thanks to the "Transport and Telecommunications" sub-sector by accounting for $0.76 \%$ in 2003 followed by the "Other Services" sub-sector $(0.50 \%$ and "Trade" $(0.34 \%)$.

As for employment, final domestic demand remains the biggest contributor to GDP growth. In 2003 , final consumption, led by private consumption, accounted for $3.2 \%$ of GDP growth as 
against $4.7 \%$ in 2002 . Gross investments accounted for $2.1 \%$ as against -0.6 in 2002 . Private investments recorded the highest contribution with $0.8 \%$

\subsubsection{Real per capita GDP growth rate}

The per capita GDP grew by $0.8 \%$ in 2003 opposed to $1.1 \%$ in 2002 . This is in line with the trends in economic growth described above. However, in nominal terms, the indicator has been changing constantly since 1999. In effect, per capita GDP increased from CFA 124,900 in 1999 through CFA 126,856 in 2000; CFA 130,536 in 2001; CFA 132,012 in 2002, to CFA 133,128 in 2003.

\subsubsection{Inflation rate}

At $1.5 \%$, Benin witnessed a slight increase in the rate of inflation during 2003. This general stability of prices is mainly due to price declines in the "Food Products, Drinks and Tobacco" sector $(-0.3 \%)$. Notable declines included "Salt, Spices, Sauces and food products n.e.s."(-6.6\%) and "'Fish and other fresh fish products" (-1.8\%).

Table 1.2.2: Convergence Indicator of the 2003 Inflation Rate in Benin

\begin{tabular}{|l|c|c|c|c|c|c|}
\hline & Jan & Feb & Mar & Apr & May & Jun \\
\cline { 2 - 7 } Month & 2.5 & 2.4 & 2.5 & 2.5 & 2.6 & 2.4 \\
\cline { 2 - 7 } Convergence & July & Aug & Sept & Oct & Nov & Dec \\
\cline { 2 - 7 } Indicator & $1.9 \%$ & $1.7 \&$ & $1.6 \%$ & $1.6 \%$ & $1.5 \%$ & $1.5 \%$ \\
\hline
\end{tabular}

Source: DSS/INSAE, January 2004

\subsubsection{Overall deficit (payments base) and overall deficit excluding grants.}

In December 2003, the implementation of the Financial Operations of the State led to the worsening of budgetary deficits. The overall deficit (payments base) stood at $2.6 \%$ of GDP against an annual target of $2.1 \%$, representing an overrun of 0.5 point. The overall deficit excluding grants, however reached $4.6 \%$ of GDP against an annual target of $4.0 \%$. These variations were due mainly to budgetary overruns to the tune of CFAF ten billion, especially in the area of salaries and the less rigorous implementation of the policy of budgetary restrictions.

In 2003, the amount of revenue and grants received is estimated at CFAF 383.4 billion corresponding to a recovery rate of $96.5 \%$ as against the budget projections. This trend is attributable to the proper management of receipts (fiscal and non fiscal) and especially to the grants whose respective recovery rate stood at $99.1 \%$ (representing 342.9 billion) and $78.7 \%$ (40.5 billion) as against $99.7 \%$ and $20.1 \%$, respectively, in 2002 .

Fiscal revenue reached CFAF 307.2 billion representing a recovery rate of $98.3 \%$ as against budgetary targets for fiscal year 2003, and compared to $100.8 \%$ in 2002 . This slight decrease in the recovery of tax revenue is linked to Benin's VAT. In fact, VAT revenues collected in 2003 declined by $1.7 \%$ compared to the level in 2002 . 
The value of grants sourced was estimated at CFAF 40.5 billion for 2003. This improvement, as compared to 2002, can be attributed to the implementation of certain reforms that enhanced the use of loans. The recurrent grants (programs) rose to the tune of $103.2 \%$ whereas the capital grants (projects) attained a performance rate of $76.2 \%$ versus budget projections.

At the end of 2003, total expenditure and net loans stood at CFAF 436.4 billion, representing an implementation rate of $99.2 \%$ as against the budget projections. This represents a net progression as against the year 2002 when the performance rate was $89.7 \%$. Total expenditure and net loans thus increased by $15.8 \%$ compared to the performance in 2002 . In relation to the GDP, the total expenditure and net loans stood at $21.1 \%$ against an annual target of $20.5 \%$.

Capital expenditure recorded an implementation rate of $84.5 \%$. Depending on the nature of the expenditure, the position is mixed: capital expenditures financed with internal resources recorded an implementation rate of $95.1 \%$ while that of capital expenditures financed with external fund is $76.2 \%$. This is attributed to the low level of external resource mobilization due to:

(i) Donor disbursement procedures; and

(ii) Delays in project execution.

In 2003, the rate of implementation of recurrent expenditure was $109.3 \%$ as compared to the budget projections. The amount of recurrent expenditure thus implemented rose by $13.4 \%$ as compared to 2002. The noticeable increase in expenditure, in spite of restrictions on the use of telephone and electricity in the public service, during the year can be attributed mainly to the budgetary overrun recorded in projected expenses for organizing the legislative and local level elections in 2003. In fact, the expenses incurred for transfers recorded an implementation rate of $129.3 \%$ as compared to the projected figure. With regard to wages, the performance rate stood at $106.5 \%$.

Financing needs, as it would appear, were covered through internal and external resource mobilization. Thus, external financing amounted to 42.9 billion CFA Francs, with the State paying off 3.4 billion of its domestic debts. With particular reference to the mobilization of HIPC resources as at 31 December 2003, the total relief granted to Benin from 2000 came to 55.3 billion CFA Francs. In 2003, the amount of relief granted stood at 17 billion CFA Francs. 


\begin{tabular}{|c|c|c|c|c|c|c|}
\hline & \multicolumn{5}{|c|}{ Targeted } & \multirow{2}{*}{$\begin{array}{c}\text { \% of } \\
\text { Imple } \\
\text { mentati } \\
\text { on }\end{array}$} \\
\hline & 2000 & 2001 & 2002 & 2003 & $\begin{array}{l}\text { Actual } \\
2003\end{array}$ & \\
\hline Revenue and grants & 290.4 & 327.1 & $\begin{array}{c}338 . \\
3\end{array}$ & 397.4 & 383.4 & 96.5 \\
\hline Revenue (Fiscal and non fiscal & 234.1 & 247.3 & $\begin{array}{c}282 . \\
5\end{array}$ & 346.0 & 342.9 & 99.1 \\
\hline Grants & 24.2 & 46.0 & 20.1 & 51.4 & 40.5 & 78.7 \\
\hline Total Expenditure and net loans & 326.1 & 331.9 & $\begin{array}{c}357 . \\
9\end{array}$ & 440.0 & 436.4 & 99.2 \\
\hline Recurrent Expenditure & 209.4 & 231.7 & $\begin{array}{c}258 . \\
9\end{array}$ & 268.6 & 293.6 & 109.3 \\
\hline Capital Expenditure & 116.4 & 99.8 & 95.8 & 171.4 & 144.8 & 84.5 \\
\hline $\begin{array}{lll} & \text { Budgetary } & \text { contribution } \\
\text { Investment } & \end{array}$ & 29.0 & 46.7 & 46.6 & 75.1 & 72.4 & 96.4 \\
\hline External Financing & 87.5 & 53.1 & 49.3 & 96.3 & 73.4 & 76.2 \\
\hline Net Loans & 0.3 & 0.4 & 3.2 & 0.0 & -2.0 & \\
\hline Total balance (orders basis) & -35.6 & -4.8 & -19.6 & -42.6 & -53.0 & 124.4 \\
\hline Total balance excluding grants (orders basis) & -59.8 & -50.8 & -39.7 & -94.0 & -93.4 & 99.4 \\
\hline
\end{tabular}

Source: Prepared by the DGAE from data supplied by CNDLP/PS, TOFE at the end of

June, 2004.

\subsubsection{Servicing of Public Debts}

As for servicing public debt, by December 2003, external debt servicing (excluding relief) stood at CFA francs 15.7 billion as against CFA francs 19.4 billion in 2002. Consequently, the "external debt servicing/fiscal revenue" ratio was $4.4 \%$ in 2003 as against $9.4 \%$ in 2002 . This ratio, which was $15.4 \%$ on the average between 1995 and 2002, reflects the efforts made by the government in terms of sustaining the external debt as well as the positive effects of the HIPC Initiative. The debt servicing/exports ratio stood at $4.2 \%$ in 2003 , an improvement over the $15.4 \%$ average ratio for the prior seven years.

It should be underscored that the outstanding external public debt was CFA francs 832.6 billion in 2003 as against CFA francs 941.6 billion in 2002, representing a reduction of more than 90 billion CFA francs. The remaining external debt stood at $38.8 \%$, in line with the downward trend that marked the 1995 - 2002 period owing to prudent debt management policy, especially with the implementation of the HIPC Initiative. This HIPC relief was estimated at CFA francs 17.8 billion in 2002 and 16.4 billion in 2003.

With regard to domestic debt servicing, the outstanding amount was estimated at CFA francs 16.8 billion in 2003. The resultant debt servicing was also estimated at CFA francs 2.83 billion. 
Table 1.2.4: Trends in the outstanding external public debt (in billions of CFA francs)

\begin{tabular}{lcccc}
\hline Type of Loans & 2000 & 2001 & 2002 & 2003 \\
\hline Bilateral & $\mathbf{1 9 0 . 3}$ & $\mathbf{1 9 9 . 4}$ & $\mathbf{1 6 7 . 3}$ & $\mathbf{1 4 4 . 5}$ \\
Multilateral Loans & $\mathbf{7 2 0 . 2}$ & $\mathbf{7 7 5 . 0}$ & $\mathbf{7 7 4 . 3}$ & $\mathbf{6 8 8 . 1}$ \\
TOTAL & 910.5 & 974.4 & 941.6 & 832.6 \\
\hline
\end{tabular}

Source: Prepared from data supplied by the Autonomous Amortization Fund (CAA)

\subsubsection{Trade Balance excluding Re-exports}

Although it still recorded a deficit, the balance of trade excluding re-exports improved considerably between 2002 and 2003. The deficit stood at CFA francs 195.2 billion in 2003 as against a deficit of 200.0 billion CFA francs in 2002. This trend could be attributed to the fact that cotton prices remained high on the international market (while the volume of exports declined slightly).

Imports, after the significant decline of 19.8\% recorded in 2000 following the implementation of the Common External Tariff (TEC), improved slightly with the rate of growth at $7.3 \%$ in 2002 . In 2003, the FOB value of imports stood at CFA francs 472.0 billion. Exports accounted for CFA francs 293.7 billion as against CFA francs 312.1 billion in 2002, representing a drop of 5.9\%. The resultant effect is that the balance of trade deficit worsened from $8.2 \%$ of GDP in 2002 to $8.6 \%$ in 2003. The coverage rate of import by exports stood at $62.2 \%$ in 2003 as against $65.9 \%$ in 2002 .

Table 1.2.5: Abstract of the balance of payments (in billions of CFA francs)

\begin{tabular}{lcccc}
\hline & $\mathbf{2 0 0 0}$ & $\mathbf{2 0 0 1}$ & $\mathbf{2 0 0 2}$ & $\mathbf{2 0 0 3}$ \\
\hline Trade Balance & -145.0 & -131.6 & -161.0 & -178.2 \\
\hline Trade Balance (excluding re-exports) & -201.9 & -177.2 & -200.0 & -195.2 \\
\hline \multicolumn{1}{c}{ FOB Exports } & 169.8 & 273.8 & 312.1 & 293.7 \\
\hline \multicolumn{1}{c}{ Including re-exports } & 109.5 & 98.2 & 104.0 & 62.4 \\
\hline FOB Imports & 314.8 & 405.4 & 473.1 & 472.0 \\
\hline$\quad$ Including imports for re-exportation & 52.6 & 52.6 & 65.0 & 45.5 \\
\hline Net Services and Revenue & -29.3 & -42.6 & -57.5 & -48.8 \\
\hline Current Balance & -57.4 & -54.9 & -108.9 & -127.1 \\
\hline Capital account and financial operations & 121.3 & 182.4 & 53.1 & -7.5 \\
\hline Overall balance & 68.3 & 120.2 & -53.9 & -134.6 \\
\hline
\end{tabular}

Source: BCEAO, October 2004

As a result of the balance of trade trends, the current balance deficit worsened between 2002 and 2003, declining from - CFA francs 108.9 billion (representing 5.1\% of GDP) to -127.1 billion CFA francs (that is $6.1 \%$ of GDP). Excluding official transfers (grants), the current balance deficit stood at $8.2 \%$ in 2003 as against $8.3 \%$ of GDP in 2002.

Moreover, it was observed that Benin complied with three out of the four primary criteria contained in the UEMOA Multilateral Monitoring Mechanism for macro-economic policies. The one it failed to achieve was the basic budgetary balance criterion, although this had always been 
met in the past. In fact, the rate of this criterion dropped to $-1.0 \%$ in 2003 as against $1.4 \%$ in 2002 (Table 1.2.6). This is attributed to the overrun of annual targets in terms of expenditure on wages, transfers and grants and the appreciable rate of capital expenditure outlays financed from internal resources.

\section{Table 1.2.6: Trends in Primary Criteria}

\begin{tabular}{lccccc}
\hline \multirow{1}{*}{ Ratio } & Target & \multicolumn{4}{c}{ Performance } \\
\cline { 3 - 6 } & UEMOA & 2000 & 2001 & 2002 & 2003 \\
\hline Basic budgetary balance/GDP & $>=0 \%$ & 3.2 & 0.9 & 1.4 & -1.0 \\
Inflation rate & $<3 \%$ & 4.2 & 4.0 & 2.4 & 1.5 \\
Outstanding internal \& external debt/GDP & $<70 \%$ & 36.9 & 55.5 & 49.5 & 40.9 \\
New Internal and External arrears & $=0$ & 0 & 0 & 0 & 0 \\
\hline
\end{tabular}

Source: CNPE/DGAE, Report on the Implementation of Multilateral Surveillance, March 2004.

With regard to the secondary criteria, the performance recorded in the area of wage bill/fiscal revenue and public investments financed from internal resources/fiscal revenue was in compliance with the standards set by UEMOA. As far as the primary criterion is concerned, the trend has followed the same track since 2000. On the contrary, the second criterion has broken with its normal track since 2000. This performance can be attributed mainly to the increase in capital expenditure financed from internal resources, which achieved a $95.1 \%$ "record" rate of implementation in 2003 as compared to the annual projections.

\section{Table 1.2.7: Trends in Secondary Criteria}

\begin{tabular}{lccccc}
\hline \multicolumn{1}{c}{ Ratio } & Target & \multicolumn{4}{c}{ Performance } \\
\cline { 3 - 6 } & WAEM & $\mathbf{2 0 0 0}$ & $\mathbf{2 0 0 1}$ & $\mathbf{2 0 0 2}$ & $\mathbf{2 0 0 3}$ \\
& $\mathrm{U}$ & & & & \\
\hline Wage bill/Tax Revenue & $<5 \%$ & $\mathbf{3 2}$ & $\mathbf{3 2 . 0}$ & $\mathbf{3 1 . 9}$ & $\mathbf{3 3 . 5}$ \\
& & & & & $\%$ \\
Public Investments financed from internal & $20 \%$ & $\mathbf{1 5}$ & $\mathbf{1 8 . 9}$ & $\mathbf{1 6 . 5}$ & $\mathbf{2 3 . 2}$ \\
$\begin{array}{l}\text { resources/fiscal revenue } \\
\text { External current account deficit excluding } \\
\text { grants/GDP }\end{array}$ & $<5 \%$ & $\mathbf{5 . 5}$ & $\mathbf{3 . 3}$ & $\mathbf{8 . 3}$ & $\mathbf{8 . 2 \%}$ \\
Tax Revenue/GDP & $>=17$ & $\mathbf{1 3 . 9}$ & $\mathbf{1 3 . 5}$ & $\mathbf{1 4 . 4}$ & $\begin{array}{c}\mathbf{1 4 . 9} \\
\%\end{array}$ \\
\hline
\end{tabular}

Source: CNPE/DGAE, Report on the Implementation of Multilateral Surveillance, March 2004

Though this performance in terms of public expenditure on investments shows the commitment of the authorities to improve basic socio-economic infrastructure, it should be noted that this has led to worsening of the basic budgetary balance. One may think that compliance with these two criteria is not necessarily favorable to measures taken by public authorities, especially in the implementation of the PRSP.

\subsubsection{Macroeconomic Policies Implemented in 2003}

With a growth rate estimated at 3.9\% in 2003, Benin's economy remained on a steady growth path thanks to the recovery plans that have been implemented since the 1990's though this rate is on the decline compared to the targets. In 2003, the measures were strengthened and focused on 
the PRSP and the Medium Term Expenditure Framework (CDMT). Public finance policies that were implemented centered on the following key issues:

(i) Effectiveness in tax collection;

(ii) Improvement in the control of budgetary expenditure;

(iii) Efficient disbursement of fund on equipment and maintenance of public services;

and

(iv) Control of the wage bill through policies such as regular audit of the payroll of the public service and monitoring of recruitments.

In addition, the computerization of the State's entire accounting system and the system for monitoring budget execution (SIGFIP) were initiated. By far they are the most advanced, especially the remarkable effort of integrating all public expenditures (including those for public procurement) into the SIGFIP; which was non-existent in 2002. Internal control, reform of public procurement, budgetary and accounting reforms have also reached an advanced stage. With regard to public debt management, the adoption of appropriate supportive policies to improve the capacity of the departments concerned has brought about transparency in the flow and stock of domestic and external debt.

As far as program budgeting is concerned, its extension to all sector ministries is being pursued at a gradual pace in view of the difficulties of ownership within the pilot ministries. During 2003, the finance departments started, inter alia, a preliminary survey with a view to harmonizing the general tax regime with the directives at the union level. Thus, the implementation of directives No. 06/2001/CM/UEMOA, No. 07/2001/CM/UEMOA of 26 November 2001 and No. 06/2002/CM/UEMOA of 19 September 2002 will take effect from 2004.

In 2003, measures aimed at consolidating the national economic base were taken with the adoption of a systematic approach to the privatization and divestiture of agencies and companies still under State control. Thus, in 2003, one of the major policies for the modernization of the Cotonou Port found concrete expression in the computerization of the activities of the port and the setting up of a Single Window with the aim of decreasing and hastening the procedures for clearing goods. In addition, technical and financial studies have been initiated with the view to building a second deep-water port in Cotonou. Still within the framework of deepening the infrastructural base, various road construction programs were pursued and several roads as well as access roads in rural communities were regularly maintained. In 2002, roads spanning about $1,646.52 \mathrm{~km}$ were resurfaced or tarred, thus bringing the stock of national roads to about 10,340 $\mathrm{km}$. In the field of road transport, the Government of Benin held discussions with its partners for the divestiture of a Railway company jointly owned by Benin and Niger. The divestiture of the railway, which covers a distance of $579 \mathrm{kms}$, is expected to solve operational and competitiveness problems.

In agriculture, many measures were implemented, and are in the process of being reinforced. Besides cotton, new agricultural sectors (cashew nut, cassava) were identified and promoted for export as part of an ongoing diversification effort. Cotton is the major agricultural export in Benin. This sector is currently the most viable though its production has been confronted with some problems in recent years. However, the reforms undertaken in 2002 to restructure the state company (SONAPRA) in charge of managing the cotton sector are ongoing and have reached an advanced stage. Thus, after opening up the cotton-ginning sector to private companies, the 
Government has started to hand over to private operators industrial equipment managed by SONAPRA to improve the profitability.

In technology and research into new sources of energy, the process of privatization of the Posts and Telecommunications Corporation (OPT) advanced with the governmental decree separating telecommunications from postal activities and the National Savings Fund. Construction work on the gas pipeline linking Nigeria, Benin and Togo took off during the year and remains ongoing. Similarly, a survey of a regional electricity project was conducted. The successful implementation of these projects will eventually lead to a relative decrease in the cost of energy and could make the country less dependent on the outside world. Moreover, the necessary groundwork for the liberalization of the water and electricity sectors was pursued vigorously. Feasibility studies on the separation of the Electricity and Water Company of Benin (SBEE) were completed leading to establishment of the National Water Company of Benin (SONEB) and the Electricity Company of Benin.

To ensure a secure business environment, the commercial courts were strengthened in terms of human and material resources. A medium-term program for training magistrates is ongoing. In the same vein, administrative and punitive measures were taken to clean up the bench. Through these actions, many cases that were pending before the courts were quickly disposed of in the course of the year and confidence is being restored in the judicial system.

Promotion and facilitation of private national and foreign investments measures were taken to make the following institutions operational and more efficient:

(i) Processing centers in all the regions of the country with the aim of stepping up the pace of and simplifying the formalities for the setting up of companies;

(ii) Development zones for setting up industries;

(iii) Investment Promotion Center;

(iv) Investment and Lending Fund;

(v) Authorized Management Centers.

\subsection{Trends in the status of human capital, environment and analysis of policies implemented in 2003}

This section presents the results of the strategic axis 2 "Human Capital Development" through an analysis of trends in health, nutrition, education, sanitation, energy and natural environment of households. It also presents an analysis of policies implemented in 2003. Fourteen indicators are used to monitor and assess these trends.

\subsubsection{Trends in the health and nutrition sectors and analysis of policies implemented in 2003}

Seven indicators study and assess the targets in health and nutrition sectors in 2003 . They are:

- Infant Mortality Rate (IMR);

- Child Mortality Rate (TMM5);

- Maternal Mortality Rate;

- HIV/AIDS Prevalence Rate among pregnant women who attend antenatal clinics centers; 
- Malaria Mortality rate per 10,000 inhabitants;

- Rate of children aged $0-5$ years suffering from malnutrition (growth delay and emaciation);

- Effects of food poverty.

\subsubsection{Infant Mortality Rate (IMR) and Child Mortality Rate (TMM5)}

Significant efforts were made to improve the situation in this area. Indeed, the infant mortality rate dropped from 103.5 per 1,000 live births in 1996 to 94.8 per 1,000 live births in 2001, and 90.0 per 1,000 live births in 2002 (RGPH3). If this trend continues, one can expect a rate of 85.2 per 1,000 live births in 2003. An analysis based on population projections shows that the targets have been achieved. Actually, infant mortality rate was estimated at 68 per 1,000 live births in 2003 as against a target of 85.2 per 1,000. An analysis of trends in neonatal mortality rate in hospitals confirms the drop in infant mortality rate in 2003. Premature neonatal mortality rate improved between 1999 and 2002, falling from 11.9 per 1,000 live births in 1999 to 10.1 per 1,000 live births in 2002.

The census results show some disparities from one province to the other. In 2002, infant mortality rate varied between 106.0 per 1,000 and 74 per 1,000 depending on province. The highest rate $(106.0$ per 1,000$)$ was noted in Zou area and the lowest $(74$ per 1,000), in Borgou.

As for child mortality, it has decreased from 183.9 per 1,000 in 1996 to 162.7 per 1,000 in 2001 and to 146.4 per 1,000 in 2002 (RGPH3). If this trend continues, we can expect a rate of 130.1 per 1,000 in 2003. Population projections show that expected results have largely been achieved since the targeted child mortality rate is 107.2 for 2003 . The highest rate, 175.7 per 1,000 , was recorded in Zou region in 2002 and the lowest was in Borgou (117.5 per 1,000). The government of Benin has made significant efforts to reduce child mortality, but progress made in this respect has been reversed by the HIV/AIDS pandemic.

The main measures taken by the Government to reduce child mortality were: an expanded immunization program, improvement in the quality of health care, and strengthening nutritional monitoring of mothers and, especially, children.

The numerous campaigns aimed at improving the immunization rate among children and thereby reducing child mortality yielded good results. The immunization coverage is, on the whole, roughly $100 \%$. Moreover, the rates of antenatal and postnatal care coverage and deliveries assisted by qualified staff are satisfactory, thus showing that child health is receiving greater attention.

\subsubsection{Maternal Mortality Rate}

According to data collected by the General Population and Housing census carried out in 1992 and 2002, maternal mortality rate was about 474.4 per 100,000 live births in 2002, while in 1992 it was 473.2 per 100,000 live births. This represents an increase of 1.2 points in a 10 -year period. Though the situation has worsened, it is negligible and we can affirm that maternal mortality rate 
has remained stable. In other words, policies implemented did not bring about any significant drop of this rate and there still remains a lot to be done. There is a gap between rural and urban areas, with a higher rate in rural areas (505.4 per 100,000 live births in 2002). Nevertheless, a stable maternal mortality was observed in both areas during the last decade.

Diagram 1.3.1: Trends in maternal mortality per location in Benin from 1992 to 2002

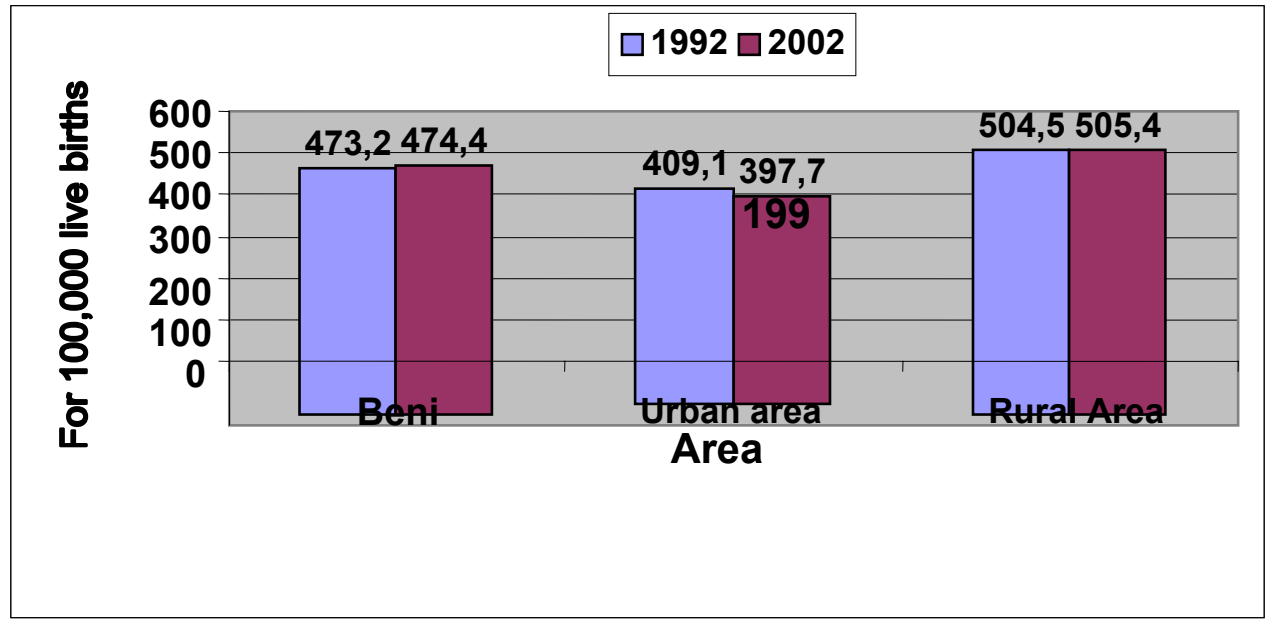

To reduce maternal mortality, the government of Benin implemented policies such as strengthening nutritional check ups for mothers, improvement in Emergency Obstetrical Neonatal Care (EONC), and Essential Neonatal Obstetrical Care (ENOC) and Information, Education and Communication Campaigns (IECC). While the coverage for antenatal care reached $91.2 \%$ in 2003, postnatal care remains low (40.7\%). Similarly, in spite of efforts to assist women during childbirth, the rate of deliveries assisted by qualified staff is only $76 \%$. In other words, approximately $25 \%$ of women needing this assistance do not get it and are exposed to all the risks related to child birth. This could account for the present mortality rate of women during childbirth.

Limited human skills also accounts for the results observed at this level. As regards human resource, there is a shortfall as a result of the massive retirement of experienced staff who are only partially replaced. Moreover, qualified staff is scarce, especially in rural areas.

\subsubsection{Rate of prevalence of HIV/AIDS recorded among pregnant women during antennal visits at health care centers}

The proportion of pregnant women with HIV/AIDS treated during antenatal visits has been declining since 2001 . From a prevalence rate of $0.3 \%$ in 1992, it gradually increased to a national level of $3.7 \%$ in 1997 and $4.1 \%$ in 2001, before dropping again to $1.9 \%$ in 2002 . It is estimated that nearly 200,000 people are currently living with HIV/AIDS. The proportion of infected people was obtained during a national survey among antenatal and IST consultants. The survey involved a larger cross-section of the population as compared to the survey carried out in 2001.

These rates do not reflect existing regional disparities. The rate of HIV infected people varies from $0.8 \%$ in Alibori department to $3.0 \%$ in Couffo. The number of infected persons is significantly higher in urban areas than in rural areas $(\mathrm{p}<0.0001)$ 
Diagram 1.3.2: Trends in the prevalence of HIV infection at the antenatal clinics in Benin from 1990 to 2002.

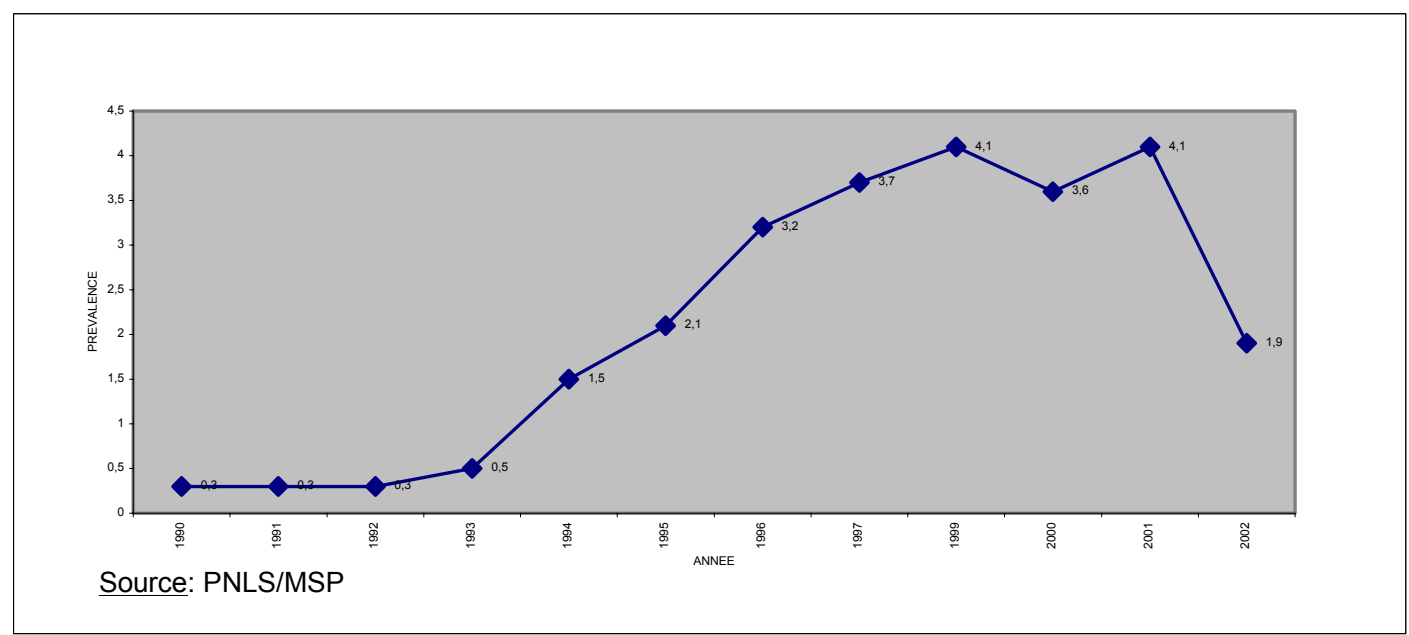

The negative effects of pandemic on households, the community and the country is alarming. This situation is worsened by the fact that a substantial part of the country's financial resources is devoted to AIDS' patient health care while these resources are badly needed to solve other development problems in Benin.

With its dire effects on life expectancy, HIV/AIDS adversely affects our society and its consequences are far more important than the immediate pain endured by those infected. Therefore, there is the need to meet the challenges (the IEC, the fight against harmful cultural practices, appropriate reproduction health care services) to stabilize or even reverse the spread of HIV/AIDS by 2025.

The various strategies to fight the pandemic have led to the following interventions:

Formation, sensitization and communication campaigns for behavior change are being pursued, especially:

- sensitization campaigns targeting youth, women and the population at large through various media (TV, press, community channels, local radio);

- publishing and distributing cartoons in schools, designing leaflets, gadgets and banners to sensitize;

- testimonies by persons living with HIV in schools, garrisons as well as high-risk groups and ministries during the establishment of focal units for the fight against AIDS

- 'STOP AIDS' at common borders with neighboring countries involving political and administrative authorities;

- creating various NGOs involved in information, education and communication activities and formation of community channels;

- creating focal points for the fight against AIDS in Ministries;

- organizing events on the World AIDS Day;

- organizing of best media productions contests on STI/HIV/AIDS;

- promoting, marketing and distributing condoms: condoms are available thanks to Population Service International (PSI) country wide. USAID also assists in that respect. 
Medical care service for STI and follow-up on sex workers the following measures were taken:

- adoption of a STI medical care service algorithms following the syndrome approach, algorithms review don't get algorithm usage, supervision of STI and HIV/AIDS among sex workers. The Canadian Cooperation, through projects such as SIDA1, SIDA2 and SIDA3 concentrate its activities on medical care services for sex workers. USAID provides medical care service through Africare/BHAPP project in the Atlantic, MonoCouffo and Zou-Collines departments

\section{Transfusion safety and biological activities:}

- establishment of a referral laboratory and regional laboratories (ELISA and rapid tests, CD 4 counting at the reference laboratory);

- provision of reagents and organization of quality control system for laboratories, HIV testing for voluntary blood donors. GIP-ESTHER project is a partnership between hospitals in France and Benin that assists in the fields of medical care and laboratory services. Presently, activities are focused on Cotonou and Porto-Novo where a virology laboratory is being set up.

PVHIV medical care service: It takes care of opportunistic infections with generic drugs, psycho-social care and combination therapy with antiretrovirals; assistance to orphans; and setting up "l'Initiative Béninoise d'Accès aux antirétroviraux" (Initiative for access to Antiretroviral).

\subsubsection{Malaria mortality rate per 10,000 inhabitants}

In 2002, malaria accounted for $37 \%$ of the patients' visits to in health care centers. This rate has not changed in 2003. Deaths due to malaria have decreased from 316 per.10,000 cases to 70 per 10,000 cases in 2002, then to 11.6 per 10,000 cases in 2003.

Generally speaking, men (83 out of 10,000 cases) are more affected than women (57 out of 10,000 cases) and the rate varies by province.

Diagram 1.3.3: Lethality of Malaria by province in Benin in 2002

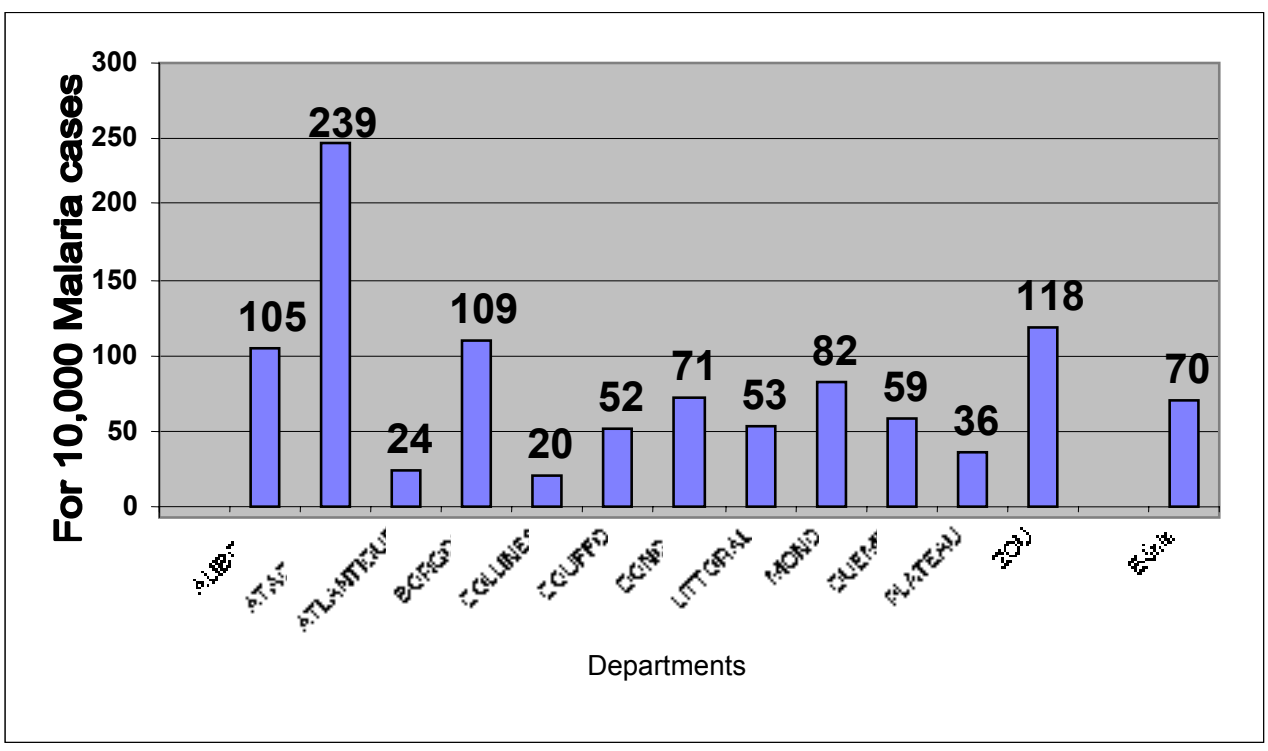


Government policy in the fight against malaria, which is implemented by the national malaria control program within the framework of the "Roll back Malaria" initiative, aims at:

- $\quad$ achieving a $30 \%$ reduction of morbidity caused by malaria by 2005 ;

- $\quad$ achieving a $30 \%$ reduction of mortality due to malaria by 2005

\subsubsection{Proportion of children aged 0 - 5 years suffering from malnutrition}

Malnutrition is still a source of great concern and testifies to the impact of poverty on a large section of the population. Several studies have confirmed that malnutrition affects a child's health, increasing the risks of sickness and death.

Chronic malnutrition is the effect of poor diet over a long period and can be aggravated by chronic diseases. In 2001, 30\% of children aged 0- 59 months suffered from chronic malnutrition, which later lead to stunted growth. The situation is different from one province to the next.

A differential analysis per area shows that $33 \%$ of children in rural areas are experiencing stunted growth. $19 \%$ of children in the capital city are suffering from chronic malnutrition. In other cities, the rate of stunted growth is $26 \%$. There is no significant difference between the rate of stunted growth in children in rural areas and those in urban areas.

An analysis based on data from EDSB I and II showed that growth retardation worsened between 1996 and 2001. Actually 30\% of children aged 0-5 suffered from stunted growth in 2001 as against $25 \%$ in 1996 . However, emaciation in children aged $0-5$ has declined from $14 \%$ in 1996 to $8 \%$ in 2001 .

\subsubsection{Impact of food poverty}

Chronic malnutrition that leads to growth retardation is strongly linked to the amount of food consumed. It actually stems from food insufficiency over several months, if not for several years. It is difficult to control this type of malnutrition since according to a QUIBB survey (2003), about a quarter of the Beninese population is so poor that it cannot meet its food requirements. This extreme poverty varies from one area to the other and appears to be more severe in rural areas where $26 \%$ of the population is poor as against $14 \%$ in urban areas.

Table 1.3: Incidence of extreme poverty by location

\begin{tabular}{|l|c|c|c|c|}
\hline Extreme poverty & $\begin{array}{c}\text { Proportion of the } \\
\text { population }\end{array}$ & $\begin{array}{c}\text { Section of the population } \\
\text { below poverty line (P0) }\end{array}$ & $\begin{array}{c}\text { Proportionate } \\
\text { deprivation default } \\
\text { (P1) }\end{array}$ & Poverty gap (P1/P0) \\
\hline Urban & 36.3 & 0.14 & 0.04 & 0.25 \\
Rural & 63.7 & 0.26 & 0.07 & 0.25 \\
Benin & 100.0 & 0.22 & 0.05 & 0.25 \\
\hline
\end{tabular}

Source : QUIBB 2003

1.3.2. Education and literacy program trends and analysis of policies implemented in 2003

Three indicators were used to analyze trends as regards education and literacy programs. They are:

- Literacy rate 
- Number of children admitted into primary school

- Number of children who completed primary school.

\subsubsection{Literacy Rate}

In spite of efforts made by the Government since the advent of democracy, the majority of the population remains illiterate. According to an estimate by DNAEA (National Directorate for Adult Literacy and Education) based on RGPH3 data, the national literacy rate was $62.3 \%$. This represents a slight regression as compared to 2001. This improvement is encouraging and implies that it would be possible to go beyond the $59 \%$ target.

This achievement is due to: (i) gradual awareness among illiterates about their effects of their illiteracy on their socio-economic life; (ii) several sensitization and information campaigns organized by the Ministry to promote education; (iii) general mobilization of political and administrative authorities and Non Governmental Organizations to reduce illiteracy; (iv) assistance from partners in building classrooms.

In spite of unavailability of data for 2003, prior year data show significant disparities between genders and regions.

\subsubsection{Gross Rate of Admissions into Primary School (GRA) and percentage of girls registered in $C I$}

Within the framework of poverty reduction, the government policy aims at increasing the GRA from $93 \%$ to $96 \%$ between 2003 and 2005 .

The general access level to primary school in Benin has increased significantly between 1995 and 2002. The GRA soared from $63.0 \%$ in 1995 to $111.3 \%$ in 2002 . This performance is the result of various initiatives by stakeholders to increase school infrastructure and ensure quality education for children.

Table 1.3.2: Trends in Gross rates of admissions

\begin{tabular}{|c|c|}
\hline YEAR & GRA (in \%) \\
\hline 1995 & $\mathbf{6 3 . 0}$ \\
\hline 1998 & 74.9 \\
\hline 2000 & 76.1 \\
\hline 2002 & $\mathbf{1 1 1 . 3}$ \\
\hline 2003 & 93.1 \\
\hline
\end{tabular}

Source : MEPS, 2003

Table 1.3.3 shows that at national level, the GRA was estimated at 93.1\% in 2003. However, gender-based differences still remain in most departments. We note a $16 \%$ gap between boys and girls. Therefore, there is still much to be done to achieve gender equality as regards access to schools and to ensure a universal education for girls. 
Table 1.3.3: Gross rate of admissions at regional and national level in 2003

\begin{tabular}{|l|c|c|c|}
\hline \multirow{2}{*}{\multicolumn{1}{c|}{ DEPARTMENTS }} & \multicolumn{3}{|c|}{ GRA } \\
\cline { 2 - 4 } & Male & Female & Total \\
\hline ATACORA-DONGA & $\mathbf{7 7 \%}$ & $\mathbf{6 2 \%}$ & $\mathbf{7 0 \%}$ \\
\hline ATLANTIQUE-LITTORAL & $\mathbf{9 9 \%}$ & $\mathbf{8 6 \%}$ & $\mathbf{9 3 \%}$ \\
\hline BORGOU-ALIBORI & $\mathbf{5 4 \%}$ & $\mathbf{4 7 \%}$ & $\mathbf{5 0 \%}$ \\
\hline MONO-COUFFO & $\mathbf{1 2 1 \%}$ & $\mathbf{1 0 0 \%}$ & $\mathbf{1 1 1 \%}$ \\
\hline OUEME-PLATEAU & $\mathbf{1 1 5 \%}$ & $\mathbf{9 3 \%}$ & $\mathbf{1 0 4 \%}$ \\
\hline ZOU-COLLINES & $\mathbf{1 1 9 \%}$ & $\mathbf{9 6 \%}$ & $\mathbf{1 0 7 \%}$ \\
\hline BENIN & $102.3 \%$ & $83.6 \%$ & $93.1 \%$ \\
\hline
\end{tabular}

Source : MEPS, 2004

This trend is generally encouraging and could be partially attributed to more rigorous national policies, including:

- The gradual involvement of communities (Parents' Associations) and Non Governmental Organizations in the management of schools;

- $\quad$ An efficient planning of strategic activities selected by MEPS and its decentralized structures;

- $\quad$ The drawing up of a CDMT and a sector program budget based on schooling challenges;

- $\quad$ The gradual understanding of the program budget preparation process and effective involvement of all necessary structures and authorities; and

- $\quad$ The conversion of poverty reduction strategies into short- and medium-term action plans to achieve effectively the objectives.

\subsubsection{Proportion of children having completed primary school}

This indicator represents the proportion of a class of pupils reaching the last grade of primary school (CM2) known in Benin as TAP (Primary School Completion Ratio). The poverty reduction strategy aims at increasing the TAP from $46 \%$ in $2001-2002$ to $56 \%$ in $2005-2006$ with a $51 \%$ target in 2003 .

Table 1.3.4: Trends in rates of completion of primary education

\begin{tabular}{|c|c|c|c|c|c|c|}
\hline Year & $\begin{array}{c}\text { Completion ratio } \\
\text { (MF) }\end{array}$ & $\begin{array}{c}\text { New comers CM2 } \\
(\mathrm{MF})\end{array}$ & \begin{tabular}{|c|} 
Surveyed pop \\
aged 11 \\
(MF) \\
\end{tabular} & $\begin{array}{c}\text { Completion ratio } \\
\text { F }\end{array}$ & $\begin{array}{c}\text { New comers } \\
\text { CM2 } \\
\text { F } \\
\end{array}$ & $\begin{array}{c}\text { Surveyed pop } \\
\text { aged } 11 \\
\text { F } \\
\end{array}$ \\
\hline $1996 / 1997$ & $36 \%$ & 59209 & 165210 & & & \\
\hline $1997 / 1998$ & $38 \%$ & 63422 & 168890 & & & \\
\hline $1998 / 1999$ & $37 \%$ & 63974 & 171850 & $24 \%$ & 21248 & 87741 \\
\hline $1999 / 2000$ & $40 \%$ & 70431 & 174656 & $27 \%$ & 24086 & 89249 \\
\hline $2000 / 2001$ & $43 \%$ & 76887 & 177729 & $30 \%$ & 26925 & 90953 \\
\hline $2001 / 2002$ & $46 \%$ & 83344 & 181183 & $32 \%$ & 29763 & 92812 \\
\hline $2002 / 2003$ & $49 \%$ & 90936 & 184924 & $3 \%$ & 32896 & 94795 \\
\hline $2002 / 2003$ & $51 \% * *$ & 93889 & 184924 & $36 \% * *$ & 34593 & 94795 \\
\hline
\end{tabular}

Source: MEPS, 2004 * TAP targeted in 2003 ; MF : Male Female; F : Female 
In 2002-2003, TAP increased slightly from $46 \%$ in $2001-2002$ to $49 \%$ in $2002-2003$, a threepercentage point increase over a one-year period. This increase was higher for girls (four points) showing the efforts made to reduce disparities and dropouts (especially desertions) or their direct and indirect causes. However, these rates remain inadequate due to the high number of grade repeats within the primary cycle, given that as at 2003, of 100 children enrolled at the same time in primary school less than half had completed primary school.

The gap observed is due, among other things, to:

- $\quad$ Non-completion of all strategic actions started by MEPS due to a low mobilization of the necessary resources to achieve the targets; and

- Divergent opinions of various stakeholders on the matter of repeating grades, hence the delays in taking appropriate measures to eliminate it permanently from the cycle in order to avoid dropouts and retain children in school.

It is vitally important to complete these actions by appropriate and rigorous monitoring and evaluation. However, progress is inadequate since, in this era of basic education for all, children of school going age must have access to schools. There is a 24.7 points difference to be dealt with to achieve the goal of providing access to school for all children by 2015 .

\subsubsection{Trends in the sanitation, energy and environmental situation and analysis of policies implemented in $\mathbf{2 0 0 3}$}

The situation with regard to sanitation, energy and environment was analyzed using four indicators:

- $\quad$ Percentage of the population having access to fresh water;

- $\quad$ Percentage of households having private latrine;

- $\quad$ Rate of access to public source of electricity by households;

- $\quad$ Rate of deforestation due to uncontrolled bushfires.

\subsubsection{Potable Water}

Access to potable water is a crucial element for people's health and is one of the Government's anti-poverty priorities. It is a major challenge to provide access to potable water for everyone. In 2003 , the PRSP projected that $70.3 \%$ of the population should have access to it. Unfortunately, the risks posed by water-related diseases are still high in Benin. In 2002, 61\% of the population had access to potable water; $22 \%$ of this water was provided by the former SBEE (Benin Electricity and Water Company); $15.5 \%$ by village standpipes; $8.3 \%$ by protected wells; and $5.7 \%$ by public drinking fountains. However, $39 \%$ of the people endanger their health by getting water from unsafe sources: unprotected wells $(22.6 \%)$, rivers and streams $(13.2 \%)$, cisterns and other sources (3.1\%) 


\section{Diagram 1.3.4: Supply of potable water per source of supply}

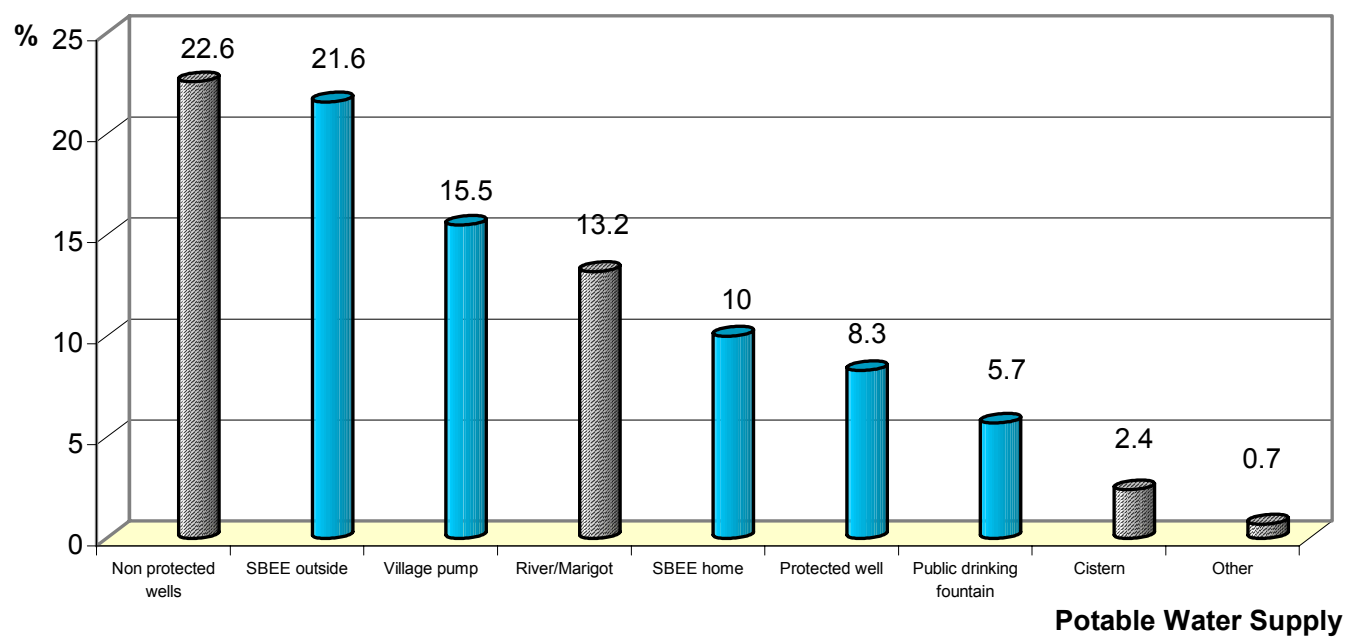

Source : INSAE, RGPH3, 2003

Significant disparities still exist between departments and areas.: lowest rate of access to potable water are recorded in the North, 37\% (Donga), 41\% (Alibori), 50\% (Atacora) and 52\% (Borgou). Rural areas are generally at a disadvantage compared to urban areas.

Diagram 1.3.5 Supply of potable water per source and region

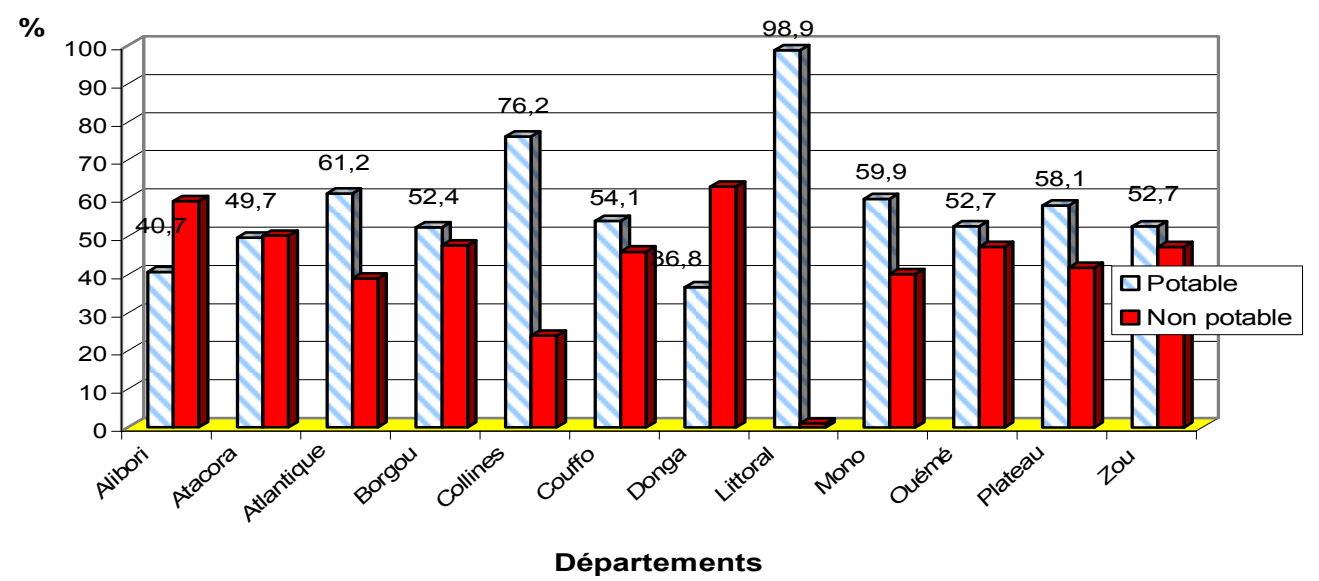

Source : INSAE, RGPH3, 2003

The rate of access to potable water has remained stable in recent years (61.1\%). The current situation shows a 9-point deficit compared to the 2003 target (70.3\%). At that rate, it is unlikely that the $78 \%$ target 
set for 2015 can be achieved. This is due to the lack of a water management strategy prior to 2003 . Moreover until 2004, reforms at the former company in charge of water supply (SBEE) that led to the separation of "water" and "electricity" had little impact.

However, efforts are being made to revamp water production. Thus, apart from the restructuring at SBEE, the government has recently set up an important program estimated at CFAF 10 billion and known as "Water for Life". The implementation of these measures augurs well for 2004.

\subsubsection{Latrines}

In the PRSP there are plans to increase the percentage of households having access to private latrines to $45.5 \%$ in 2003. In 2002, only one-third of households had toilet facilities: ventilated latrines (13.6\%), non-ventilated latrines $(12.5 \%)$ and flush toilet $(2.8 \%)$. The majority of households does not have toilets and defecate in the open. Faecal matter-related risks are therefore high especially in rural areas since surface waters are sources of drinking water. While the situation is acceptable in coastal areas where people defecate less in the open (17.6\%), it is critical in other regions where the rate of access to latrines is between 10 and $23 \%$.

\section{Diagram 1.3.6: Proportion of the population per type of toilet}

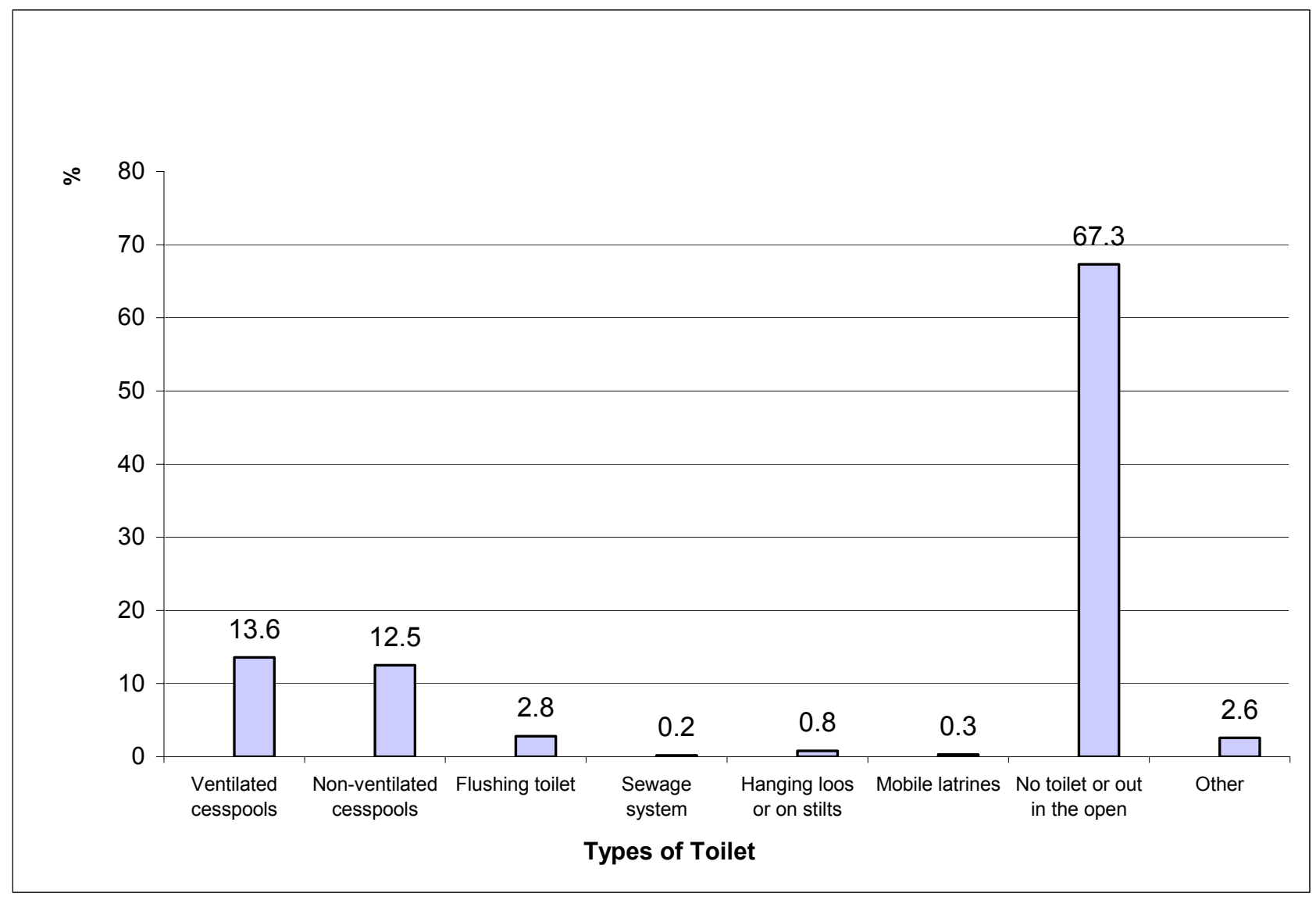

Source : INSAE, RGPH3, 2003 


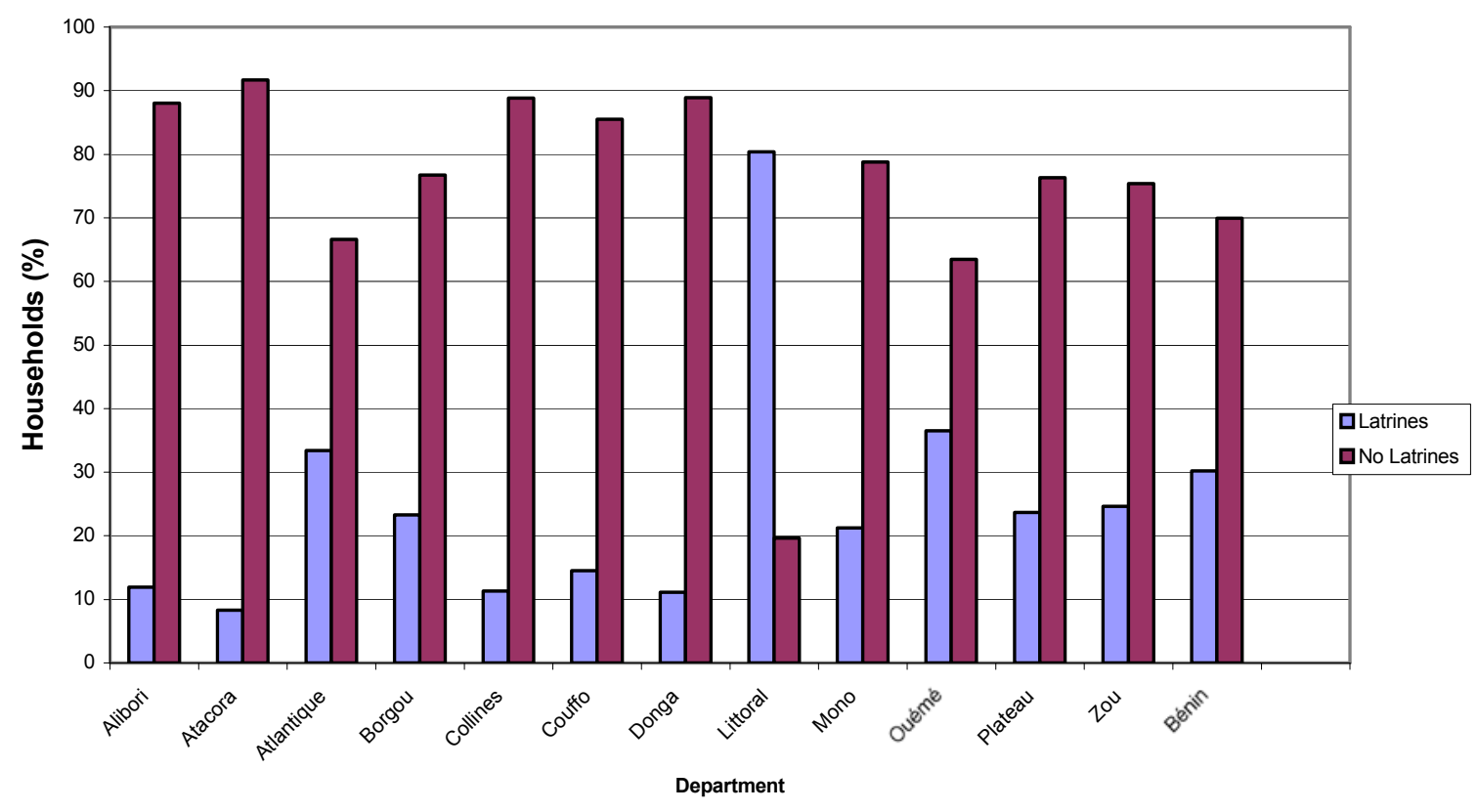

Source: INSAE, RGPH3, 2003

When compared to 2001, the rate of access to latrines has improved slightly from $32.1 \%$ to $32.6 \%$ (a 1.6\% increase). However, in 2003 the gap (12.4\%) is still great between the target $(45.5 \%)$ and the actual rate (33.1\%). This deficit is due to the fact that the provision of latrines is not as systematized as the supply of potable water for example. Evidence to this fact is the lack of measures in the PRSP to reach the targets. Consequently, there is need to hold discussions with the Ministry of Health through the DHAB (Directorate for Public Health and Sanitation) to provide an appropriate strategy in the PRSP since the provision of latrines are part of basic sanitation. Obviously, to achieve the aim of increasing the number of available latrines, it is essential to reinforce sensitization at the national level.

\subsubsection{Energy}

According to RGPH-3 results, only one in five households (22.4\%) have access to a public source of electricity. The target for 2003 was to provide electricity to $28.7 \%$ of households. In view of the gap to be filled $(6.3 \%)$ within a year, it is not likely that the target can be achieved.

Due to this deficit, $77 \%$ of households still use paraffin oil for lighting. The use of paraffin oil is characteristic of rural households (94.9\%). In urban areas, $46.8 \%$ of households use electricity.

Access disparities between regions to a public source of electricity are as follows: the Littoral is first with $69.9 \%$, followed by Ouémé (30.8\%) and Atlantique (20.9\%). In the other regions less than one household out of 5 have access to electricity. The situation is difficult in Alibori (5.4\%), Atacora (5.6\%), Donga (5.9\%) and Collines (6.9\%). Zou, Mono, Couffo and the Plateau are in an intermediary position with respectively $17.4 \%, 15.3 \%, 9.9 \%$ and $9.5 \%$ of their households having access to electricity. 
Diagram 1.3.8: Proportion of households with access to public sources of electricity per department

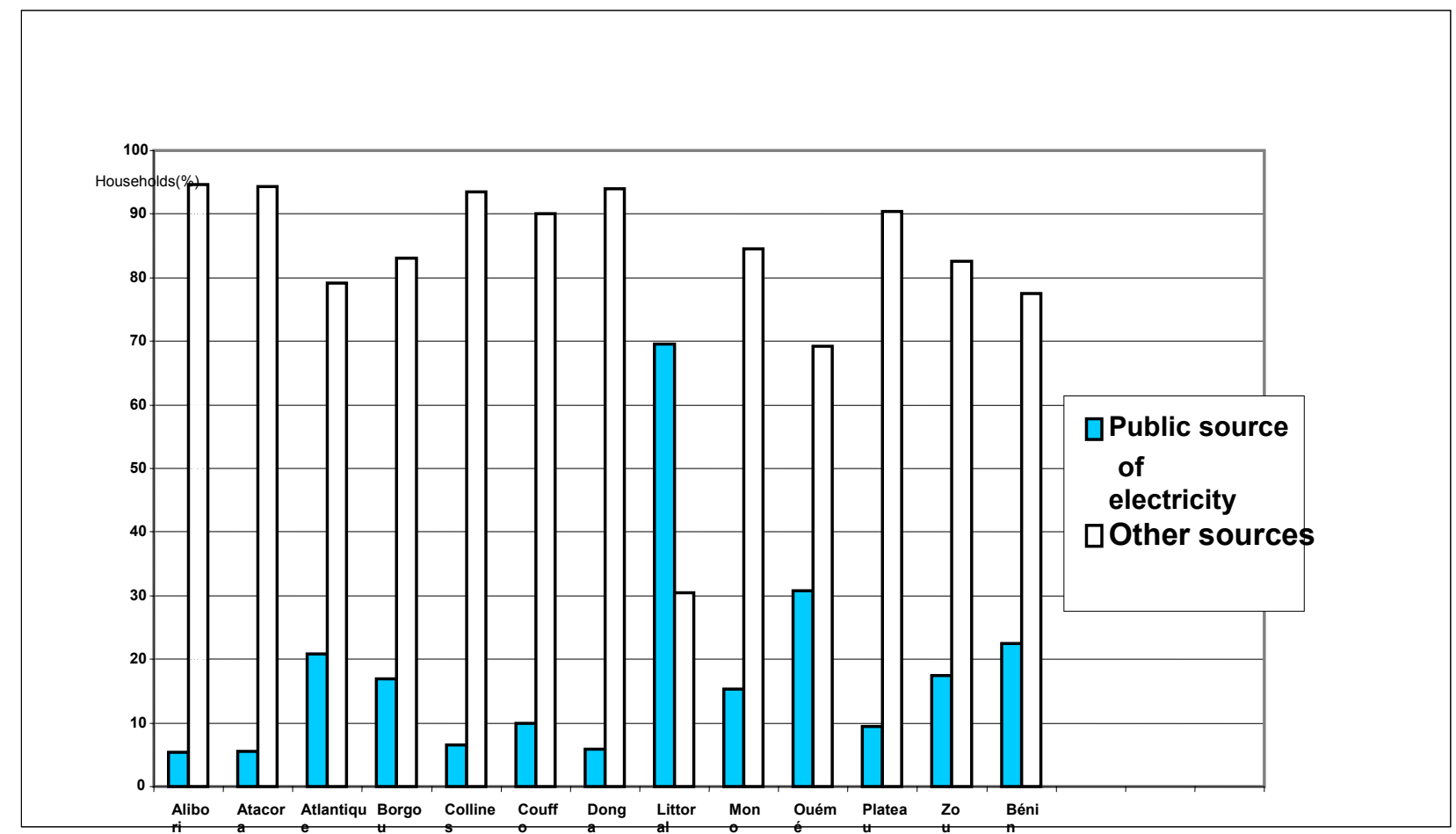

Source : INSAE, RGPH3, 2003

Thanks to the SBEE achievements in connecting and bringing electricity to rural areas, there was an increase in electricity coverage from $22.4 \%$ in 2002 to $26.5 \%$ in 2003.

Reforms carried out at SBEE led to a separation of « water » and « electricity » sectors and ended in the creation of a company that will concentrate its resources (physical, human and financial) on meeting people's electricity needs in urban and rural areas. The results of these reforms will be materialized in 2004.

\subsubsection{Environment}

The only indicator retained in this report for the assessment of the natural environment is the rate of deforestation caused by uncontrolled bushfires. Unfortunately, in spite of the relevance of this indicator, according to the DFRN (Directorate for Forests and Natural Resources) of MAEP, available information cannot be used to assess progress made in 2003. 


\subsection{Trends in Governance and institutional capacities and analysis of policies implemented in 2003}

Governance and institutional capacity trends are assessed using seven indicators:

- Rate of execution of budgeted recurrent expenditure, excluding wages, in PERAC Ministries

- Rate of execution of budgeted capital expenditure in PERAC Ministries

- Average procurement cycle (type of procurement, ministry)

- Average time frame for payment of government expenditure (type of contract, ministry)

- Percentage of government expenditure (investment and operation) actually allocated to priority sectors (priority Ministry)

- Amount of national budget actually transferred to local government

- Women participation index.

\subsubsection{Rate of execution of budgeted recurrent expenditure, excluding wages, in PERAC ministries}

Generally speaking, current expenditures excluding wages in priority ministries are high. However, there are sector-related disparities. The average for 10 ten priority ministries was $98 \%$ over the 2001-2003 period. This average is higher than the targeted value in $2003(96.04 \%)$ computed based on public expenditure trend scenario 1 (of the PRSP). Such a performance is due to a better utilization of budget credits. There was even an implementation rate higher than $100 \%$; this was the case for the Ministry of Environment, Housing and Country Planning (MEHU) in 2001. This situation is due to either to previous year credits carried forward, or to the utilization of additional resources that are not included in the budget but considered as contributions.

\subsubsection{Rate of execution of budgeted capital expenditure in PERAC Ministries}

The average execution rate of budgeted capital expenditure in PERAC ministries during 20012003 is lower $(71.18 \%)$ than the current expenditure, excluding wages budget, execution rate, while the targeted value for 2003 calculated on the basis of scenario 1 (PRSP) of national expenditure trend is $100 \%$. The average execution rate of capital expenditure has declined steadily over the 2001-2003 period: $100.5 \%$ in 2001, $64.3 \%$ in 2002 and $60.9 \%$ in 2003.

The low rate of capital expenditure execution in PERAC ministries over the period should be of concern for the ministries involved. However, it should be noted that $59.7 \%$ of the government investment budget come from development partners and sponsors and are subject to special disbursement procedures that are not sufficiently understood by the recipient.

The major problems hindering projects implementation and limiting the utilization of credit are as follows:

- Late start-up of implementation of planned activities. This is due to a delay in procurement and to the lack of operations and procurement plans; 
- Lack of knowledge in the new government expenditure procedures and in the use of SIGFiP software due to the mobility of trained users;

- Relative weakness in conceptual and managerial capacities of some project managers;

- Procedure for the disbursement (partial disbursement) of project funds stipulated in management sub contracts;

- Late signature of management contracts with some implementation agencies;

- Cumbersome disbursement procedures resulting in slow project implementation, particularly in the area of social infrastructures.

There is the need to solve these problems in order to ensure that the fight against poverty is not adversely affected by the failure to use resources allocated to sector-based ministries.

\subsubsection{Average time frame for public procurement}

The expected results were not achieved in 2003. The average time frame for awarding public procurement contracts was 64.3 days for suppliers while the target period was 55 days. With regard to services, the average time frame noted was 104.4 days against a target of 63 days. The average time frame for the works was 95.7 days against a target of 78 days. Consequently, there is much to be done to reduce the delay in awarding public procurement contracts.

Table 1.4.1: Trends of average time frame for award of contract per type of procurement (all ministries included)

\begin{tabular}{|l|c|c|c|c|}
\hline \multirow{2}{*}{ Types of contracts } & $\mathbf{2 0 0 2}$ & \multicolumn{2}{|c|}{2003} & \multirow{2}{*}{$\begin{array}{c}\text { Differenc } \\
\text { e }\end{array}$} \\
\cline { 2 - 4 } & $\begin{array}{c}\text { Reference } \\
\text { figure }\end{array}$ & $\begin{array}{c}\text { Actual } \\
\text { figure }\end{array}$ & Target & \\
\hline Supplies & $\mathbf{5 8}$ & $\mathbf{6 4 , 3}$ & 55 & $-9,3$ \\
\hline $\begin{array}{l}\text { Services, small and average } \\
\text { works }\end{array}$ & 67 & 104,4 & 63 & $-41,4$ \\
\hline Major works & $\mathbf{8 0}$ & $\mathbf{9 5 , 7}$ & $\mathbf{7 8}$ & $-17,7$ \\
\hline
\end{tabular}

Source : DGML/MFE, 2004

\subsubsection{Average time frame for payment of national expenditures}

There was a one-day improvement in the average time frame for the payment of national expenditure between 2001 and 2002 in most of the ministries with a net improvement in PERAC ministries. We noted a significant improvement of this time frame in 2003 as compared to 2002 with different trends from one ministry to the other. Nevertheless, the target of 20 days set in the PRSP was not achieved for the year 2003. Much effort is still required to fill the gap.

A possible solution to that problem is to involve all ministries in the budgetary reform, ensure a continuous training of officers at all levels without foregoing a reorganization of structures in charge of the payment for public expenditures.

\subsubsection{Percentage of government expenditure (investment and operation) actually made in priority sectors}


Priority ministries considered in this report are those identified by the government as having a particular role to play in the fight against poverty. There was an increase in public expenditure in priority sectors between 2001 and 2002. It remained the same (about 36\%) in 2003. This rate appears low in the context of poverty reduction, especially for ministries whose activities should have a rapid effect on poverty.

However, it would be difficult to envisage an increase of the budgetary allocation to sector ministries since the resources granted are supposed to cover all planned activities. Moreover, when we consider the budget execution rate of these ministries, it appears that, on the average, they use only $70 \%$ of the resources they projected for themselves. Thus, the problem lies in actual capacity of these priority ministries to use their credits.

Table 1.4.2 : Share of public expenditure (capital and recurrent) actually made in priority sectors (key ministries)

\section{Capital and recurrent expenditure}

2001

2002

2003

Ministry of Justice, Legislation and Human Rights

\begin{tabular}{lccc}
\hline Ministry of Public Health & 0.51 & 0.66 & 0.84 \\
\hline Ministry of Environment, Housing and Town planning & 6.48 & 7.67 & 7.06 \\
\hline Ministry of Energy, Mines and Water resources & 5.69 & 4.91 & 3.90 \\
\hline Ministry of Public Works and Transport & 0.65 & 1.22 & 1.54 \\
\hline Ministry of Industry, Trade and Small and Medium Enterprises & 0.49 & 7.94 & 6.07 \\
\hline Ministry of Primary and Secondary Education & & 0.81 & 0.99 \\
\hline Ministry of Technical Education and professional Training & & 13.18 & 14.10 \\
\hline Importance of Priority Sectors /General Budget (\%) & 21.3 & 1.35 & 1.63 \\
\hline
\end{tabular}

Source : SIGFIP/MFE

In order to increase the share of recurrent and capital expenditure, it would not be necessary to increase the resources allocated but rather improve the budget execution rate.

\subsubsection{Share of the national budget actually transferred to local government}

From 2001 to 2003 , credits allocated to local government have been included in the national budget. However, few resources have been actually transferred to them. The expenditure execution rate for local government has been steadily declining from 2001 to 2003. The low execution rate in 2002 and especially in 2003 was due to the fact that, since 2002, Benin entered a decentralizations phase during which all authorities have not yet been transferred and capacities have not yet been strengthened at local level. It is obvious that the resources allocated are largely below the needs of local governments in a context of poverty reduction with basic development as a government priority. It is necessary to take measures to increase not only the execution rate but also the funds allocated to local governments. The portion of capital expenditure in the overall budget allocated to local government is low in terms of projections and realizations. Actually, less than $1 \%$ of the overall budget is allocated to local governments as funds or commitments. 
Table 1.4.3: Proportion of funds allocated to local government from total budget

\begin{tabular}{|c|c|c|c|c|c|c|}
\hline \multirow[b]{2}{*}{ Years } & $\begin{array}{c}\text { Total funds of the } \\
\text { budget }\end{array}$ & $\begin{array}{c}\text { Funds } \\
\text { allocated to } \\
\text { Local } \\
\text { governments } \\
\end{array}$ & \multirow{2}{*}{$\begin{array}{c}\text { Proportion of } \\
\text { funds allocated } \\
\text { to local } \\
\text { government } \\
(\%) \\
\end{array}$} & $\begin{array}{c}\text { Total } \\
\text { commitments of } \\
\text { the budget } \\
\end{array}$ & $\begin{array}{c}\text { Total } \\
\text { commitments of } \\
\text { local government }\end{array}$ & \multirow{2}{*}{$\begin{array}{l}\text { Proportion of } \\
\text { commitments } \\
\text { for local } \\
\text { governments } \\
(\%)\end{array}$} \\
\hline & \multicolumn{2}{|c|}{$\begin{array}{l}\text { (in millions of } \\
\text { CFAF) } \\
\end{array}$} & & \multicolumn{2}{|c|}{$\begin{array}{l}\text { (en millions } \\
\text { F CFA) } \\
\end{array}$} & \\
\hline 2001 & 160860 & 1050 & 0.65 & 128011 & 329 & 0,26 \\
\hline 2002 & 175628 & 1134 & 0.65 & 118739 & 151 & 0,13 \\
\hline 2003 & 169827 & 915 & 0.54 & 123281 & 10 & 0,01 \\
\hline
\end{tabular}

Source : Execution report of the National Total Budget 2001, 2002 and 2003.MFE

\subsubsection{Women's participation index}

Women participation Index (WPI) (see table 1.4.4) shows the efforts made to encourage women to participate in the sustainable human development process of a country. It takes into account the level of advancement and empowerment of women. The indicators increased from 2000 to 2002 and subsequently decreased in 2003. The variation between 2003 and 2002 is due to the reduction in the number of female Members of Parliament from five in 2002 to four in 2003.

There was a slight increase of women's participation and decision-making capacity in the economy from 0.610 in 2000, to 0.702 in 2001 and 0.777 in 2002-2003. This improvement is due, on one hand, to a conscious effort made by Beninese society to offer women opportunities and on the other hand, to a better awareness to take advantage of these opportunities by women.

\section{Table 1.4.4 : Trends in Women's participation index (WPI)}

\begin{tabular}{|c|c|c|c|c|c|}
\hline \multirow[b]{2}{*}{ Indicator } & \multirow[b]{2}{*}{ Criteria } & \multicolumn{4}{|c|}{ Year } \\
\hline & & 2000 & 2001 & 2002 & 2003 \\
\hline \multirow{2}{*}{$\begin{array}{l}\text { Participation and } \\
\text { decision-making } \\
\text { capacity in politics }\end{array}$} & Female parliamentary representation $(\%)$ & 6.02 & 6.02 & 6.02 & 4.82 \\
\hline & $\begin{array}{l}\text { Equal distribution percentage indicator (PEER- } \\
\text { 1) }\end{array}$ & 0.222 & 0.222 & 0.224 & 0.181 \\
\hline \multirow{3}{*}{$\begin{array}{l}\text { Participation and } \\
\text { decision-making } \\
\text { capacity in the } \\
\text { economy }\end{array}$} & Managers and executives (\%) & 16.8 & 18.9 & 22.5 & 22.5 \\
\hline & Technicians et members of liberal professions & 21.6 & 28.9 & 26.7 & 26.7 \\
\hline & $\begin{array}{l}\text { Equal distribution percentage indicator (PEER- } \\
\text { 2) }\end{array}$ & 0.610 & 0.702 & 0.777 & 0.777 \\
\hline \multirow[t]{2}{*}{$\begin{array}{l}\text { Control of economic } \\
\text { resources }\end{array}$} & $\begin{array}{l}\text { Estimated Proportion of women's work as } \\
\text { compared to men's }\end{array}$ & 0.45 & 0.67 & 0.83 & 0.83 \\
\hline & $\begin{array}{l}\text { Equal distribution percentage indicator (PEER- } \\
\text { 3) }\end{array}$ & 0.013 & 0.021 & 0.045 & 0.050 \\
\hline $\begin{array}{l}\text { Women's participation } \\
\text { index }\end{array}$ & & 0.281 & 0.315 & 0.348 & 0.336 \\
\hline
\end{tabular}

Source : $\quad 1.2000$ and 2001 Values taken from RNDH -2003

2. Values for 2002 and 2003 are calculated by CAPE in collaboration with INSAE, on the basis of RGPH3 data, indicator of public service, RNDH 2000. 


\section{NOTE ON THE METHOD USED IN CALCULATING THE WPI}

Women's participation indicator (WPI) is made up of variables clearly defined to measure the control that men and women can have over their political and economic destiny.

The first set of variables takes into account the economic decision-making capacity. It includes the percentage of men and women occupying administrative and supervisory position on one hand, and technical and liberal professions on the other. These represent very large occupational categories and they are generally defined. Since the population groups concerned by these two large categories are different, their indicators are calculated separately and subsequently added up.

For each of these two categories employment, we apply the IS average method $(1-\epsilon)$ to calculate an equivalent percentage equally distributed (PEER) for both genders considered jointly. To ensure coherence with the gender sensitive Human Development Indicator (ISDH), the value of the parameter of aversion towards inequality is set to 2 . Since society hates inequality, the PEER will have the same social value with unequal percentages translating occupational situation of men and women. In case of perfect gender equality, the PEER would be $50 \%$. The greater the differences between genders, the lower the PEER. It can vary between 50\% (maximum and 0\% (minimum). Following indexation, equally weighted indicators in both employment categories are added up.

The second variable, the percentage of men and women having a seat in Parliament was chosen to reflect participation and political decision-making capacity. As was previously done for participation and economic decision-making capacity, we calculate the average $(1-\epsilon)$ of these two percentages to obtain the PEER and subsequently index it.

The variable chosen to designate the control of economic resources is the actual non-modified GDP per inhabitant (stated in PPA). We obtain the proportional part of equally distributed income by calculating the average $(1-\in)$. The real non-adjusted per capita GDP is multiplied by this coefficient (less than 1).

If there were gender equality, this factor and the actual non-modified GDP per inhabitant would not be subjected to weighting.

Lastly, the sum of the three variables indicators is divided by 3 to obtain the general WPI

Source : World Report on Human Development (1995), RNDH (2000)

\subsection{Trends in mutual support groups and the capacity of the poor to participate in decision- making and production and analysis of policies implemented in 2003.}

The development of solidarities and poor people's ability to participate in decision-making and production processes was discussed through four indicators:

- $\quad$ Percentage of the total number of districts covered by a district development plan;

- $\quad$ Percentage of number of districts covered by a communal development program;

- $\quad$ Rate of penetration of decentralized financial services (area, type, region)

- $\quad$ Percentage of the total number of districts that are inaccessible during the rainy seasons

\subsubsection{Communal Development plan}


As at December 31 2003, only 8 of Benin's 77 districts had designed and adopted a communal development plan. These are mainly small towns that started the design of a CDP before the district was set up. However, it is encouraging to note that communal planning process is ongoing in all the other districts. In fact, the district is required by law to design and adopt its local development plan and see to its implementation (Law No. 97-029, paragraph 84 dated 15 January 1999 on district organization in Benin).

By the end of 2004, all districts should have a development plan which will serve as a political contract, a social development contract, a negotiation tool with the State and partners, a management tool with the ultimate objective of developing the district and improving the welfare of its people.

\subsubsection{Communal Development Program}

As regards the percentage of districts covered by communal development programs, several projects have been initiated and implemented at the community level to promote grassroots development and build people's capacity to enable them to participate in decision-making and development of their towns. These projects are spread countrywide. Thus, all districts in Benin are covered by a communal development program/project.

\subsubsection{Decentralized Financial Services}

The rate of penetration of decentralized financial services reached $26.3 \%$ in 2003 according to figures provided by the Micro finance Group. Thus, a little over a quarter of the poor but economically active section of the population have access savings and loans services of microfinance institutions (MFI). This rate is still very low when compared to the Government targets of poverty reduction. In order to improve it, there is the need to build the capacities of Microfinance Units and immediately put in place the SFD Support Fund to improve the intervention capacity and ability to meet the communities' expectations.

Unfortunately, data are not available to calculate indicators and district, MFI, gender basis, etc. There is the need to systematically collect data in MFI countrywide to facilitate the regular calculation of these indicators. This will contribute to a better assessment of poor's access to savings and loans services and possibly take the necessary corrective measures.

\subsubsection{Inaccessible districts during rainy seasons}

Apart from eight (Karimama, Sègbana, Malanville (on the way from Karimama), So-ava, Bonou, Aguégués, Ouessè, Djidja and Ouinhi) out of a total of 77 districts of Benin, all other districts capitals are accessible during rainy seasons. However, some villages or small towns become inaccessible during rainy seasons. In that sense, all Benin districts have problems with accessibility during rainy season. This situation is more acute in rural areas than in urban areas.

The issue of improved access to small towns through the development of rural roads remains a primary concern in the fight against poverty as this will enable people to have access anytime and anywhere to basic social services and markets. 


\subsection{Cross-cutting Issues}

Two main cross-cutting issues were addressed in this first PRSP 2003-2005 implementation progress report namely, gender and children's issues.

\subsubsection{Trends in gender issues in $\mathbf{2 0 0 3}$}

The PRSP clearly states that the Government will support gender promotion. The objective is to reduce gender inequalities regardless of age and development sector. To achieve this, the following activities are being carried out: improvement of girls and women schooling, fight against female genital mutilations, support for women's associations and to women in general, promotion of women and girls' rights, institutional development for the promotion of women's role.

To reduce poverty, gender issues have been taken into account at all levels of the strategy and are perceived as a cross-cutting development tool. The PRSP indicates the main activities retained for 2003-2005. They are:

- $\quad$ Implementation of the multisector action plan of the PNPF;

- $\quad$ Improvement of the Beijing Action program;

- $\quad$ Increased access to loans for women;

- Increased support to women's associations involved in income-generating activities;

- $\quad$ Improvement of vocational training for women artisans;

- $\quad$ Measures to encourage the enrolment of girls to school and their stay;

- $\quad$ Support to the training center for dropped-out girls;

- $\quad$ Support to the retraining of female genital mutilation practitioners;

- $\quad$ Training of women associations in food processing and conservation.

In 2003, efforts were made to take into account gender issue in development programs and a special emphasis was put on woman promotion. In particular, the government harmonized and rationalized gender issues-oriented policies presently disseminated in sectoral strategies.

Significant efforts have been made to enroll girls in schools but wide gaps still exist between boys and girls in primary, secondary schools and higher education as indicated in table 1.6.1 to 1.6.3. Between 2000 and 2003, the trends in the gap between boys and girls in terms of gross schooling rate were uneven and reached 32 points in 2003. As regards the net rate, the gap is 28 points. The situation is even more critical in higher education where the gaps are as high as 46 points for vocational training and nearly 65 points for general training.

Table 1.6.1: Gross rate of enrolment in \% in the Primary level

\begin{tabular}{|l|c|c|c|c|}
\hline Year & Girls & Boys & Together & Gap B/G \\
\hline $\mathbf{2 0 0 0}$ & $\mathbf{6 5 . 1 6}$ & $\mathbf{9 4 . 4 3}$ & $\mathbf{7 9 . 9 9}$ & 29.27 \\
\hline $\mathbf{2 0 0 1}$ & $\mathbf{7 2 . 3 3}$ & $\mathbf{1 0 4 . 3 9}$ & $\mathbf{8 8 . 4 9}$ & 32.06 \\
\hline $\mathbf{2 0 0 2}$ & $\mathbf{7 2 . 1}$ & $\mathbf{1 1 0 . 4 6}$ & $\mathbf{9 4 . 3 3}$ & 38.36 \\
\hline $\mathbf{2 0 0 3}$ & $\mathbf{8 2 . 0 3}$ & $\mathbf{1 1 4 . 3}$ & $\mathbf{9 8 . 3}$ & 32 \\
\hline
\end{tabular}

Sources : Statistics Directory, 2000-2003 
Table 1.6.2 : Net rate of enrolment at the secondary level

\begin{tabular}{|l|c|c|c|c|}
\hline Year & Girl & Boy & Together & Gap B/G \\
\hline $\mathbf{2 0 0 0}$ & $\mathbf{2 5 . 3 4}$ & $\mathbf{5 2 . 2 2}$ & $\mathbf{3 8 . 9 3}$ & 26.88 \\
\hline $\mathbf{2 0 0 1}$ & $\mathbf{2 7 . 6 9}$ & $\mathbf{5 6 . 0 4}$ & $\mathbf{4 1 . 9 9}$ & 28.35 \\
\hline $\mathbf{2 0 0 2}$ & $\mathbf{2 3 . 8 7}$ & $\mathbf{5 2 . 1 1}$ & $\mathbf{3 8 . 0 6}$ & 28.24 \\
\hline
\end{tabular}

Sources : Secondary Education Statistics Directory

Table 1.6.3 :Vocational or academic education : percentage of students by type of education

\begin{tabular}{|l|c|c|c|c|c|c|}
\hline Year & \multicolumn{2}{|c|}{ Girls } & \multicolumn{2}{c|}{ Boys } & \multicolumn{2}{c|}{ Gap } \\
\hline & General & Vocational & General & Vocational & General & Vocational \\
\hline $\mathbf{2 0 0 0}$ & $\mathbf{2 2 , 2}$ & $\mathbf{2 6 . 8}$ & $\mathbf{7 7 . 8}$ & $\mathbf{7 3 . 2}$ & 55.6 & 46.4 \\
\hline $\mathbf{2 0 0 1}$ & $\mathbf{2 1 , 0}$ & $\mathbf{2 7 . 1}$ & $\mathbf{7 9}$ & $\mathbf{7 2 . 9}$ & 58 & 45.8 \\
\hline $\mathbf{2 0 0 2}$ & $\mathbf{1 7 , 8}$ & $\mathbf{2 7 . 0}$ & $\mathbf{8 2 . 2}$ & $\mathbf{7 3}$ & 64.4 & 46 \\
\hline
\end{tabular}

Source : SSS/RECTORAT/UAC 05/08/03

Several legal provisions were made in 2001 and 2003 to correct some disparities:

- Family Act 2002-07 passed its first reading on June 72002 at the National Assembly. Unfortunately, the Supreme Court has rejected the Law as it contravenes some constitutional provisions. The relevant provisions are being reviewed by the National Assembly to ensure conformity with the constitutional.

- Act 2003-04 on sexual and reproductive health adopted on 3 March 2003;

- Act No. 2003-03 forbidding the practice of female genital mutilations adopted on 3 March 2003 in the Republic of Benin;

- The Abuja Convention on HIV/AIDS, tuberculosis and others.

In the field of microfinance, significant efforts were made by the Government in 2003 to enable the poor, especially women, to have access to loans at subsidized rates through the set up of the Support Fund for National Solidarity (FASN). The number of persons who have benefited from of this Joint Associations Fund is 3,748, including 1,332 men and 2,416 women. A total of 5,926 persons were granted loans through the FASN.

Table 1.6.4 : Number of beneficiaries of FASN loans in 2003

\begin{tabular}{|c|c|c|c|c|c|}
\hline \multicolumn{2}{|c|}{ Beneficiaries of private loan } & \multicolumn{2}{|c|}{ Beneficiaries of group loan } & \multicolumn{2}{|c|}{ Total beneficiaries } \\
\hline Men & Women & Men & Women & Men & Women \\
\hline 340 & 1,838 & 1,332 & 2,416 & 1,672 & 4,254 \\
\hline \multicolumn{2}{|c|}{2,178} & \multicolumn{2}{|c|}{3,748} & \multicolumn{2}{|c|}{5,926} \\
\hline
\end{tabular}

Source : MFPSS, 2004

Concerning women in rural areas, the government has promised to facilitate their access to land and to revise the current land code. The bill on Rural and National Land Code made provision for rural women, especially the article 10 that specifies the right of all citizens to have access to agricultural lands without discrimination based on sex and in accordance with the provisions of relevant laws and regulations. 
On the whole, gender issues have been effectively taken into account in development programs. However, there is still a lot to be done in the field of girls' schooling to achieve the Millennium Development Goals.

\subsubsection{Situation of children in 2003}

In spite of significant efforts by the government, children's situation is not that bright in Benin. Though child mortality rate declined between 1996 and 2001 from $94 \%$ to $89 \%$, it remains one of the highest in Africa. The main cause of AIDS in children is the transmission from mother to child. Data from RGPH3 do not indicate the level of prevalence.

The study of parents' survival indicates that the parents of the majority of children aged 0-5 (99\%) are still alive. However there is a relatively high proportion of children who have lost their father, numbering nearly $18,776(1.6 \%) ; 6,919$ children have lost their mothers $(0.6 \%)$ and 1,035 children have lost both their fathers and mothers $(0.1 \%)(\mathrm{RGPH} 3,2002)$. The proportion of orphans remains relatively high among children aged 10-14, regardless of the type of orphans considered. Actually, the proportion of fatherless children in this group is the highest $(7.7 \%)$, followed by motherless children $(3.5 \%)$ and both fatherless and motherless children $(0.8 \%)$, while among children aged 5-9 it is respectively $4.3 \%, 2.0 \%$ and $0.3 \%$. These high proportions of all types of orphans raise the crucial problem of their care as regards their education and selffulfillment and this could lead to an upsurge in the number of abandoned and street children (RGPH3, 2002)

In spite of the prohibition on child labor for children under 14 by the International Labor Organization (ILO) and by Benin Laws, we noted that more and more children are involved in the economic activities of the country. To appreciate the scope of this phenomenon, questions related to economic activities were put to all persons aged from 6 upward during the third General Population and Housing census in 2002, contrary to the 1992 census during which only those aged 10 and above were required to answer these questions.

Some of the children aged 6-14 are working. Data from TGPH3 show that in Benin, out of 906,917 children aged 6-9 registered in February 2002, 232,564 that is one out of 4 children $(25.6 \%)$ are working. Among these children, there is a majority of girls, that is $55.1 \%$ against $44.9 \%$ of boys. Most of these children work in the informal sector (99.5). Out of a total of 807,919 children aged 10-14 who answered the questions about their activities, 247,681 are active $(30.7 \%)$ and 560,238 are not $(69.3 \%)$.

The distribution by district of children in their households shows that the majority of them live with their parents. A low proportion of them live outside their family; that is, they are not related to the head of the household. This proportion is relatively higher in the regions of Donga $(4.2 \%)$, Atlantique (3.8\%), Atacora (3.5\%), Littoral (3.2\%) and Borgou (2.5\%) than in other regions. The census results, indicates that children are entrusted to different household based on a notion of group solidarity still operating in the North. Thus, the number of children entrusted to other households is relatively higher in the following regions: Donga $(2.9 \%)$, Borgou $(2.0 \%)$ and l'Alibori (1.9\%). 
This situation was of concern for the Government throughout the year 2003. Sensitization campaigns and the establishment of the Minors Protection Brigade have led to a steady in child trafficking (from 1,059 cases in 1998 to 102 cases in 2002).

Education centers for the rehabilitation of exploited children and functional literacy have been created in twelve social promotion centers countrywide.

In the Atlantique, Mono, Couffo, Plateau and Donga regions, 1,043 committees have been set up in villages to help in the fight against child trafficking and promote enrolment of children in schools, especially girls, childbirth in maternities homes and births registration.

In 2002, the government launched a project for the increase of child survival in four regions (Zou, Collines, Ouémé, Plateau; total population of 2.2 million) including activities such as the distribution of treated mosquito nets, an Expanded Immunization Program (PEV); provision of vitamin A supplement to significantly reduce mortality rates.

\section{PROGRESS REPORT ON THE IMPLEMENTATION OF PRSP MATRIX OF MEASURES IN 2003}

To provide an update on the implementation of the PRSP matrix of measures for $2003-2005$, various reports prepared by the authorities concerned were explored. Information gathered during these reviews were complemented and validated by a survey among Directors in charge of Planning and Projections (DPP) of sector ministries concerned and technical agencies responsible for areas in question when DPPs were not available to respond to the questionnaires. The assessment of the level of implementation of actions and measures planned for 2003 can be qualitative and/or qualitative.

From the quantitative point of view, an overall implementation index ${ }^{4}$ was calculated for each axis using the following method: if a measure is completely implemented, one mark is awarded; if the implementation is not complete but has reached a very advanced level, 0.5 is awarded; in all other cases " 0 " is awarded. With this method, the following results presented in the table below were obtained.

Table 2.1.1: Index for the implementation of the matrix of measures

\begin{tabular}{|l|l|l|l|l|}
\hline & & $\begin{array}{l}\text { Score } \\
\text { obtained }\end{array}$ & $\begin{array}{l}\text { Max } \\
\text { Score }\end{array}$ & $\begin{array}{l}\text { Achievement } \\
\text { Index }\end{array}$ \\
\hline Axis. 1 & Strengthening of medium term macro-economic framework & 22.5 & 46 & 0.489 \\
\hline Axis2 & Human capital development and environmental management & 28 & 53 & 0.528 \\
\hline Axis 3 & Strengthening of good governance and institutional capacity building & 6 & 22 & 0.273 \\
\hline
\end{tabular}

${ }^{4}$ The marks 0, 0.5 and 1 are awarded to each measure depending on whether i) the implementation of the measure has not or has barely started, ii) it has reached an advanced level and iii) it is completed. The maximum score for a given measure is 1 . An average mark is then calculated based on all measures envisaged under a sub axis of the strategic axis and for all strategic axes. The score achieved is the sum of marks obtained for all measures under a sub axis of the strategic axes or all 4 axes. The maximum score is equivalent to the number of measures evaluated under the sub axis, the strategic axis or the totality of the axis. The achievement index is the ratio of the score obtained and the maximum score which can be expressed in percentage terms. 


\begin{tabular}{|l|l|c|c|c|}
\hline Axis 4 & $\begin{array}{l}\text { Promotion of sustainable employment and capacity building for the } \\
\text { poor to participate in decision making and production process }\end{array}$ & 20 & 31 & 0.645 \\
\hline All axis combined & 76.5 & 152 & 0.503 \\
\hline
\end{tabular}

Source: CNDLP/PS, 2004

On the whole, this table shows that the implementation of the matrix of measures is at an average level. In fact, the level of implementation is estimated at 50.3\%. This is mainly due to the delays recorded in the area of strengthening good governance. Indeed, many measures concerning strengthening good governance and institutional capacity building were not implemented to an appreciable level, bringing the index down to $27.3 \%$ for this axis. There is the need for serious efforts to raise the level of this index. Efforts are also required to bring to an average level "axis 1" which involves the implementation of measures aimed at strengthening the medium-term macroeconomic framework. An analysis of the various axes on individual basis gives a better understanding of the level of these indicators.

\subsection{PROGRESS MADE IN 2003 IN RESPECT OF AXIS 1 MEASURES: STRENGTHENING OF MEDIUM TERM MACRAOECONOMIC FRAMEWORK}

An analysis of the situation shows that the overall level of implementation of measures relating to strengthening medium-term macroeconomic framework is $48.9 \%$. This IS below the average of the four axes $(50.3 \%)$.

Table 2.1.1: Level of implementation of measures for strengthening medium term macroeconomic framework.

\begin{tabular}{|c|c|c|c|}
\hline & $\begin{array}{l}\text { Score } \\
\text { achieved }\end{array}$ & $\begin{array}{l}\text { Max. } \\
\text { possible } \\
\text { score }\end{array}$ & $\begin{array}{l}\text { Achievement } \\
\text { Index }\end{array}$ \\
\hline 1-1.Consolidation of sources of growth & 12 & 21 & 0.571 \\
\hline a- Agriculture. Animal rearing. Fishing and Handicrafts & 8 & 12 & 0.667 \\
\hline Agriculture & 3.5 & 6 & 0.583 \\
\hline Land issues & 0.5 & 1 & 0.500 \\
\hline Animal rearing & 1 & 1 & 1.000 \\
\hline Fishing & 0.5 & 1 & 0.500 \\
\hline Handicraft production & 2 & 2 & 1.000 \\
\hline Cottage industries & 0.5 & 1 & 0.500 \\
\hline$b$-Service Sector & 2 & 4 & 0.500 \\
\hline Tourism & 1 & 2 & 0.5 \\
\hline $\begin{array}{l}\text { New information and communication } \\
\text { technologies (NICT) }\end{array}$ & 1 & 1 & 1 \\
\hline Promotion of intermediary activities & $\mathbf{0}$ & 1 & 0.0 \\
\hline c-Industrial Sector & 2 & 5 & 0.400 \\
\hline $\begin{array}{l}\text { 1-2.Strengthening basic infrastructures for factors of } \\
\text { production available and at reduced costs }\end{array}$ & 10.5 & 25 & 0.420 \\
\hline a-Energy, Water and Mines & 4.5 & 11 & 0.409 \\
\hline Energy & 1 & 4 & 0.250 \\
\hline Water & 1.5 & 2 & 0.750 \\
\hline Mines & 2 & 5 & 0.400 \\
\hline
\end{tabular}




\begin{tabular}{|l|c|c|c|}
\hline B Post and Telecommunication & 0.5 & 2 & 0.250 \\
\hline c- Transport Infrastructure & 5.5 & 12 & 0.458 \\
\hline Road and Rail Transport & $\mathbf{2}$ & $\mathbf{4}$ & $\mathbf{0 . 5 0 0}$ \\
\hline Maritime Transport and Ports & $\mathbf{1 . 5}$ & $\mathbf{3}$ & $\mathbf{0 . 5 0 0}$ \\
\hline Air Transport & $\mathbf{2}$ & $\mathbf{5}$ & $\mathbf{0 . 4 0 0}$ \\
\hline Total for axis 1 & 22.5 & 46 & 0.489 \\
\hline
\end{tabular}

Source: CNDLP/PS. 2004

A differentiated analysis based on sets of measures indicates that the implementation of measures concerning strengthening basic infrastructure for factors of production at reduced has been considerably delayed, judging from the average of this axis. In fact, the level of implementation is estimated at $42 \%$. This could, among others, be attributed to the substantial delays recorded in the implementation of measures relating to post and telecommunication where the rate of implementation is estimated at $25 \%$. Indeed, the privatization of the public telecommunications operator scheduled initially for July 2003 is yet to be realized though the separation of the two entities i.e. post and telecommunication is achieved.

Poor performance has also been observed in the area of transport infrastructure where the percentage of implementation is $45.8 \%$. At this point, it is worth noting that the delays recorded are essentially due to the air transport sub sector where only $40 \%$ of measures expected in 2003 were implemented. Thus, the measure concerning private sector participation in the management of Cotonou Port scheduled for June 2003 has not yet been completed. Phase two which involves a feasibility study on the scenario retained and phase 3 concerning the implementation of the said scenario are yet to begin.

With regard to policy measures on energy, water and mines, substantial progress has been observed in the water sub sector where $75 \%$ of improvement measures were implemented. However, considerable delays were noted in the energy sub sector which recorded $25 \%$ in terms of level of implementation. In fact, for this sub sector, the measure recommending establishment of a regulatory body, initially scheduled for June 2003, was not achieved. This is currently rescheduled for December 2004. The same delay has been observed in entrusting the management of the electricity sector to private operators. In fact, initially scheduled for April 2003, the management arrangement is currently projected for the second semester of 2005. This huge laps raises questions as to how realistic is the implementation of this measure.

Concerning measures on the consolidation of sources of growth, their level of implementation were higher than the average of the four axes, reaching $57.1 \%$. The sub group of measures namely, agriculture, animal breeding, fishing and handicraft production account mostly for the achievement of this rate, with an outstanding score of $66.7 \%$. The most outstanding contributions to this sub group are attributed to agriculture, animal breeding and handicraft production and for that matter the timely implementation of measures on animal breeding and handicraft production sub sectors. On the contrary, serious delays were recorded in the agriculture sub sector as far as the implementation of some measures was concerned. The aims of these measures were to:

- $\quad$ Privatize the SONAPRA industrial plants; this measure was supposed to be implemented by May 2003 but it is still not completed. 
- $\quad$ Conduct agricultural research and create conditions to make seeds, seedlings and other agricultural inputs available at reduced costs; planned for the period 2003 - 2004, no concrete action was taken in 2003. The study on the seed sub sector is scheduled to start in March 2004.

A lot remains to be done at the sub group level on measuring the services and industrial sectors. For example, with regard to intermediary sub sectors, the only measure concerning a specific research on intermediary activities scheduled for August 2003 has not been implemented.

\subsection{PROGRESS MADE IN RESPECT OF MEASURES UNDER AXIS 2: HUMAN CAPITAL DEVELOPMENT AND ENVIRONMENTAL MANAGEMENT}

The implementation of measures under axis 2 reached a level of $52.8 \%$, which is slightly above the overall level for the four axes. This was achieved thanks to the implementation of measures in educational and health sectors as well as the nutrition sub sector. The contribution of sanitation, energy and natural environment sub sectors seems to be generally low.

Table 2.1.3: Level of implementation of measures on human capital development and environmental management

\begin{tabular}{|l|c|c|c|}
\hline Sub group of measures & $\begin{array}{l}\text { Score } \\
\text { achieved }\end{array}$ & $\begin{array}{l}\text { Possible } \\
\text { maximum } \\
\text { score }\end{array}$ & $\begin{array}{l}\text { Achievement } \\
\text { Index }\end{array}$ \\
\hline Health and Nutrition & 10 & 17 & 0.588 \\
\hline Health & 7 & 12 & 0.58 \\
\hline Nutrition & 3 & 5 & 0.60 \\
\hline Education & 10 & 15 & 0.67 \\
\hline Sanitation, Energy and natural environment & 8 & 21 & 0.38 \\
\hline Total for axis 2 & 28 & 53 & 0.528 \\
\hline
\end{tabular}

Source : CNDLP/PS, 2004

\subsubsection{Progress made in 2003 in respect of axis $\mathbf{2}$ measures on health and nutrition}

To solve health and nutritional problems, several measures were retained for implementation during the period $2003-2005$. The results of the implementation of these actions are presented in table 2.1.4. Thus, in the area of health and nutrition the level of implementation of measures is estimated at 58.8\%. The level of implementation does not differ much between the health and nutrition sectors. This shows clearly that during the first year of implementation of the PRSP, appreciable efforts were made in terms of applying policy measures on health and nutrition. However, these measures were not enough to reflect an improvement in health indicators and contribute to the achievement of set targets. 
Table 2.1.4 Level of implementation of measures on health and nutrition

\begin{tabular}{|l|c|c|c|}
\hline Group of measures & $\begin{array}{l}\text { Score } \\
\text { achieved }\end{array}$ & $\begin{array}{l}\text { Possible } \\
\text { maximum } \\
\text { Score }\end{array}$ & $\begin{array}{l}\text { Achievement } \\
\text { Index }\end{array}$ \\
\hline Health & 7 & 12 & 0.58 \\
\hline Nutrition & 3 & 5 & 0.60 \\
\hline Health and Nutrition & 10 & 17 & 0.588 \\
\hline $\begin{array}{l}\text { Human capital development and environmental } 28 \\
\text { management }\end{array}$ & 53 & 0.528 \\
\hline
\end{tabular}

Source : CNDLP/PS, 2

The multiplicity of players in the health and nutrition sector (NGO, public and private sectors, religious groups, foreign partners, local representatives, decentralized administrations), the multitude of actions and the need to ensure the success of these interventions call for stronger coordination and coherent monitoring and evaluation of performance in the health and nutrition sector. It is for this reason that all these actions must be supported by a coordination process as well as the monitoring and evaluation of indicators inbuilt in planning and program structures and strengthened by focal points located within major projects/programs and technical or central agencies.

\subsubsection{Progress made in 2003 in respect of measures under axis 2 concerning education ${ }^{5}$ and literacy}

Table 2.1.5 presents the overall indicator for the implementation of measures concerning education for the period $2003-2004$ within the poverty reduction strategy. These measures include both those contained in the PRSP and those supported by the Initial Support Credit for Poverty Reduction.

It may be recalled that these various measures aimed at improving access to quality education and ensuring the participation of communities in the management of schools were retained based on the following principles:

- $\quad$ The interventions were targeted at areas where poverty is most acute;

- The 2004 budget was used to correct departmental disparities in terms of education especially at the primary level.

Table 2.1.5 Level of implementation of measures on education

\begin{tabular}{|l|c|c|c|}
\hline Group of measures & Score achieved & Possible maximum score & Achievement index \\
\hline Education & 10 & 15 & 0.67 \\
\hline $\begin{array}{l}\text { Development of human capital and } \\
\text { environmental management }\end{array}$ & 28 & 53 & 0.528 \\
\hline
\end{tabular}

Source: CNDLP/PS, 2004

${ }^{5}$ Including technical education and professional training 
The table above shows that the level of implementation hit $67 \%$ whilst that of the axis on the whole was $52 \%$. It appears that education is one of the areas where most of the measures envisaged were implemented. This explains the performance recorded in this sector in 2003. There is still the need to fully implement all other measures under the matrix.

\subsubsection{Progress made in 2003 in respect of measures under axis 2 on sanitation, energy and environment. ${ }^{6}$}

Concerning the evaluation of measures implemented under environmental management, there were indications that efforts had been made for the effective implementation of the matrix. However, there is still room for improvement. In fact, as the overall index shows, the level of implementation is $38 \%$; which is far below the average of the axis which is estimated at $52.8 \%$. This low score can partly be ascribed to shortcomings in the implementation of measures concerning potable water, environment and rural electrification where the indices are estimated at $17 \%, 38 \%$, and $0 \%$, respectively, (none of the measures aimed at rural electrification has been implemented.) Regarding the potable water sub sector, the measure on the finalization of the strategy document on potable water management has not been applied. Indeed, the drafting of the strategy document on the management of water resources, which was originally scheduled for June 2003, was suspended and it was decided that the strategy be included in the GIRE (Integrated Management of Water Resources.)

Table 2.1.6: Level of implementation of measures on environmental management

\begin{tabular}{|l|c|c|c|}
\hline Group of measures & $\begin{array}{l}\text { Score } \\
\text { achieved }\end{array}$ & $\begin{array}{l}\text { Possible } \\
\text { maximum } \\
\text { score }\end{array}$ & Achievement index \\
\hline Sanitation. energy and natural environment & 8 & 21 & 0.38 \\
\hline Potable water & 0.5 & 3 & 0.17 \\
\hline Housing & 2.5 & 5 & 0.50 \\
\hline Environment & 1.5 & 4 & 0.38 \\
\hline Sanitation & 2.5 & 5 & 0.50 \\
\hline Rural electrification & 0.0 & 2 & 0.00 \\
\hline Construction of rural access roads & 1.0 & 2 & 0.50 \\
\hline $\begin{array}{l}\text { Human capital development and environmental } \\
\text { management }\end{array}$ & 28 & 53 & 0.528 \\
\hline
\end{tabular}

Source: CNDLP/PS. 2004

The measure concerning the creation of appropriate conditions for the establishment of a bank for housing was implemented on schedule.

\footnotetext{
${ }^{6}$ Including potable water, housing, rural electrification, construction of access roads in rural areas
} 


\subsection{PROGRESS MADE IN 2003 IN RESPECT OF MEASURES UNDER AXIS 3: STRENGTHENING GOOD GOVERNANCE AND INSTITUTIONAL CAPACITY BUILDING}

An analysis of the matrix shows that the overall level of implementation is estimated at $27.3 \%$. In fact, the only measure that could be implemented effectively was the organization of municipal elections. The second one was a survey on governance. The implementation of this measure started in 2004. Only the consultant in charge of the survey was engaged in 2003.

\section{Table 2.1.7: Level of implementation of measures concerning of strengthening good governance and institutional capacity building}

\begin{tabular}{|l|c|l|l|}
\hline Group of measures & $\begin{array}{l}\text { Score } \\
\text { achieved }\end{array}$ & $\begin{array}{l}\text { Possible } \\
\text { maximum } \\
\text { score }\end{array}$ & $\begin{array}{l}\text { Achievement } \\
\text { Index }\end{array}$ \\
\hline $\begin{array}{l}\text { Fight against corruption and capacity building for the management } \\
\text { and absorption of public resources }\end{array}$ & 3.5 & 10 & 0.35 \\
\hline Acceleration of administrative reforms & 0.5 & 6 & 0.08 \\
\hline Acceleration of the decentralization process & 2.0 & 6 & 0.33 \\
\hline Strengthening good governance and institutional capacity building & 6 & 22 & 0.273 \\
\hline
\end{tabular}

Source : CNDLP/PS, 2004

There are obvious difficulties in the implementation of administrative reforms and decentralization. Indeed, all measures related to the acceleration of administrative reforms proved difficult to implement, namely: i) updating automatic promotion systems by putting in place a career and remuneration system of APEs which establish a link between salary increases and productivity in the civil service; ii) develop management contract in the civil service; iii) ensure good information flow between administrative sectors and end users, iv) implement an integrated management system of APEs and forward looking management of staff strength; v) formulate and implement a national policy on professional in-service training for the public sector; and vi) make regulatory and inspection agencies functional and apply effectively regulations governing the civil service.

There were factors exogenous to the implementation of those measures, especially social dialogue between employers and workers, which were not adequately taken into account. The ministry in charge of the civil service, employment and administrative reforms is therefore drawing up a roadmap alongside the program retained to address this issue.

The acceleration of the decentralization process is not advancing, including the transfer of powers, prerogatives and activities that are devolved upon local authorities in pursuance of laws and regulations. While some progress was made, there are difficulties, such as capacity building for local authorities, and the interpretation of texts and laws on the powers and prerogatives of the local administrations. 


\subsection{PROGRESS MADE IN 2003 IN RESPECT OF MEASURES UNDER AXIS 4; PROMOTION OF SUSTAINABLE EMPLOYMENT AND CAPACITY BUILDING FOR \\ THE POOR TO ENABLE THEM TO PARTICIPATE IN DECISION-MAKING AND PRODUCTION}

Measures used under axis 4 of the PRSP deal with the following areas:

- $\quad$ Promotion of community development

- $\quad$ Promotion of employment and income generating activities

- $\quad$ Social Protection and women's advancement

- $\quad$ Micro finance development

- $\quad$ Security for vulnerable areas

- $\quad$ Promotion of development centers

The measures retained were implemented to varying degrees in the course of 2003. In spite of an appreciable implementation index of $64.5 \%$ as against an overall index of $50.3 \%$ for all four axis, it seems there are problems with the implementation of some of the sub measures.

\section{a) Promotion of community development}

- This measure, which involves making operational the "National Community Development Program covering 300 villages to be provided with a development plan" by December 2003, was considered unrealistic and the target of 300 villages was scaled down to 150 villages. Out of the 150 villages retained, the development plans were drawn up for only 49 villages, representing an achievement rate of about $33 \%$.

- $\quad$ The two other measures concerning 100 UCDs (Communal Unit for Development) were not implemented for lack of mobilization of resources. These measures aim, among others, to: (i) implement on pilot basis development plans for 100 UCDs that have already benefited from monographic studies and (ii) support income-generating activities in the 100 pilot UCDs.

\section{b) Social and women's development}

- $\quad$ Implement the FNRB reform by adopting a strategy that will help reduce the deficit and ensure equilibrium in the short term: originally scheduled to be achieved in December 2003, the implementation of this measure is lagging far behind. A consultant was engaged in 2003 but the call for bids that will quick start the research process could not be prepared in good time.

- Take measures to encourage enrolment and retention of girls in school by December 2003. There were two series of actions that have not had a very tangible impact on the expected results. There were actions such as: (i) sensitization forums on enrolling children, particularly girls in schools, were held throughout the country; (ii) support (credits and free material) were conditioned on sending girls to school in some communities; 
- $\quad$ Support the retraining of female genital mutilation practitioners. From January to February 2003, a crusade against female genital mutilation was organized in localities where the practice was prevalent for ten days to sensitize practitioners. Are these one-off and irregular actions relevant for achieving the expected results?

\section{c) Protection for vulnerable areas}

For the four measures used at this level, so far there has not been any concrete action. These measures involve:

- Introducing a gradual modernization of agriculture and facilitating access to micro credits;

- Improving people's access to basic social services;

- $\quad$ Opening areas by building access roads in rural areas;

- $\quad$ Preventing and resolving problems resulting from transhumance

Table 2.1.8: Level of implementation of measures on promoting sustainable employment and capacity building of the poor for their participation in the decision making and production process.

\begin{tabular}{|l|c|l|l|}
\hline Group of measures & $\begin{array}{l}\text { Score } \\
\text { achieved }\end{array}$ & $\begin{array}{l}\text { Possible } \\
\text { maximum } \\
\text { score }\end{array}$ & $\begin{array}{l}\text { Achievement } \\
\text { Index }\end{array}$ \\
\hline Promotion of community development & 0.5 & 3 & 0.17 \\
\hline Promotion of employment and income generating activities & 2.0 & 3 & 0.67 \\
\hline Social security and women's development & 8 & 12 & 0.67 \\
\hline Social Security & 2 & 3 & 0.67 \\
\hline Gender and women's development & 6 & 9 & 0.67 \\
\hline Development of micro-finance & 4.5 & 5.0 & 0.90 \\
\hline Protection of vulnerable areas & 2.5 & 4.0 & 0.625 \\
\hline Promotion of development centers & 2.5 & 4.0 & 0.625 \\
\hline $\begin{array}{l}\text { Promotion of sustainable employment and capacity building of the } \\
\text { poor for their participation in the decision making and production } \\
\text { process. }\end{array}$ & 20 & 31 & 0.645 \\
\hline
\end{tabular}

Source : CNDLP/PS, 2004

An analysis of the difficulties related to implementing the various measures brings out a typology that allows classification into seven major groups, namely:

1. Measures whose implementation has been delayed because of exogenous factors like social revolt. This is especially the case of measures relating to privatization and the acceleration of administrative reforms.

2. Measures that have been delayed as a result of cumbersome procedures. This is the case of measures such as (i) conducting agricultural research; (ii) conducting a specific study on transit activities; (iii) Ensuring private sector participation in the management of Cotonou Port.; (iv) Conducting a survey on corruption and governance. 
3. Measures whose implementation is held up due to the interpretation of laws. This

is, among others, the case of the measure on transferring of powers and prerogatives to local authorities.

4. Measures for which targets were overestimated. The operationalisation of the National Community Development Program covering 300 villages is one of such measures.

5. Measures that could not be implemented due to lack of mobilization of resources. The measure on 100 UCDs is a case in point.

6. Measures for which the relevance of actions taken were not very obvious. These measures include the promotion of gender and women (retaining girls in school; female genital mutilation).

7. Measures for which concrete ways of achieving the set objectives were not well thought out. This is, among others, the measure on providing security to vulnerable areas.

In the light of genuine difficulties involved in implementing certain measures, the annual assessment of the PRSP should help draw some lessons learned about the matrix of measures. During departmental workshops to validate this report, grassroots communities called for removal of certain measures, such as privatizations and administrative reforms.

\section{IMPLEMENTATION OF PRSP MONITORING AND EVALUATION MECHANISMS AND ACTION PLAN}

\subsection{Developments in institutional framework in $\mathbf{2 0 0 3}$}

The institutional framework within which the Poverty Reduction Strategy Paper was prepared and the first year implemented was based on decree no 2000-535 of $2^{\text {nd }}$ November 2002 on the powers, composition and functions of the National Commission on Development and the Fight Against Poverty Reduction (CNDLP). This framework is a mechanism spanning three levels, starting from the district through the provincial to the central administration.

The new system created some difficulties partly due to functional and hierarchical relations that should exist between the two major organs of the National Commission i.e. the Permanent Secretariat and the Technical Committee and on the other hand, the institutional positioning of the Social Change Observatory (OCS), which happens to be the technical unit responsible for PRSP monitoring and evaluation.

Since then, there have been reflections on the issue which led to a workshop held on $6 \& 7$ March 2003 on the resumption of OCS activities. This workshop was attended by both government officials and development partners. On this occasion, the position of the OCS was discussed based on a study conducted to this effect. The study, which proposed possible locations for the 
OCS, reviewed the possibility of positioning this outfit within the National Statistical Council either as an autonomous entity of the CNDLP or as an organ of the Permanent Secretariat of CNDLP.

The workshop recommended that the authorities concerned take the final decision bearing in mind the advantages and disadvantages. In this regard, a new decree on the institutional framework of the CNDLP was passed. The new institutional framework comprises five main bodies within the CNDLP. These are: (i) the General Assembly; (ii) the Ministerial Committee; (iii) the Permanent Secretariat; (iv) the Social Change Observatory and Departmental Monitoring Committees.

\subsection{ACTION PLAN FOR 2004 AND 2005 MONITORING \& EVALUATION ACTIVITIES}

The lack of mechanisms for monitoring and evaluating the implementation of development projects and programs accounts to a large extent for the limitation of many of such programs. Aware of this constraint, the Benin government has put in place a monitoring and evaluation system to ensure the successful implementation of programs within the PRSP framework.

Thus, the entire PRSP monitoring and evaluation system is based on a mechanism made up of government, local community structures and a technical entity known as Social Change Observatory (Observatoire du Changement Social, OCS).

The aim of this section is to first of all give an update on monitoring and evaluation activities carried out in 2003 during the implementation of the Poverty Reduction Strategy (PRS). It will then provide a plan of action for 2004 and 2005 in order to resolve problems encountered by institutions in charge of monitoring and evaluation.

\subsubsection{Update on monitoring and evaluation activities during the implementation of PRSP in 2003 and difficulties encountered.}

The monitoring of the PRSP implementation process was carried out at the sectoral level by the Department of Planning and Projections of the various ministries and at the central level by the Permanent Secretariat of the National Commission for Development and the Fight Against Poverty.

\subsubsection{Sector level}

The budgetary reform has led to the restructuring of the mechanism for planning, monitoring and evaluating public expenditures. Consequently, monitoring and evaluation (M\&E) units have been established in some selected ministries on pilot basis under the PERAC. These units are, among others, mandated to:

- Monitor the implementation of activities of structures, projects and programs within their ministries based on relevant indicators;

- $\quad$ Prepare periodic report (quarterly, mid-year, and annual) on the execution of program budget in their ministries; 
- $\quad$ Analyze the relevance and performance of actions implemented in their ministries;

- Organize the monitoring of policies and programs implementation in their ministries;

- $\quad$ Lead policy and program evaluation missions of their ministries.

The main monitoring and evaluation activity noted at the level of sector ministries borders on the preparation, monitoring the execution of program budget and drafting of mid-year and annual reports as required under the budgetary reform. Some peculiarities were noted in the ministries involved.

At the Ministry of Agriculture and Fisheries, the main activity carried out in 2003 was the drawing up of a monitoring and evaluation plan of action. The preparation of this plan was decentralized. Thus, the process started with monitoring and evaluation action plans from decentralized structures of the ministry. The draft plan of action is already available.

At the Ministry of Environment, Housing and Town Planning, monitoring and evaluation is done thanks to the existence and activities of focal points for planning, monitoring and evaluation within the structures of the ministry.

At the Ministry of Public Health, it must be indicated that the National Committee on Monitoring the implementation and evaluation of Project/Programs (CNEEP) was institutionalized in 2003. This committee, which is responsible for directing the planning, monitoring and evaluation, has departmental contacts that account to the Monitoring and Evaluation Unit through the submission of quarterly and annual reports.

With regard to the private sector and civil society, the main activity carried out in terms monitoring the PRSP is the drawing up and validation of an action plan to ensure the participation of the private sector and civil society in monitoring the implementation of the PRSP. Commissions on themes were set up to prepare a draft monitoring guide for the implementation of the action plan for private sector and civil society participation in the PRSP implementation process.

Generally, like the statistical divisions, monitoring and evaluation units within the ministries are facing human resource, material and financial constraints. There is already a shortage of qualified personnel. The focal points which provide information to monitoring and evaluation units within the technical structures of ministries are not available everywhere. Where they are available, they do no have all the capacities and resources required to perform their functions. The expertise is available in the private sector and civil society, however there is the need for more structuring to ensure that the structures do not work in isolation.

Both human and material as well financial resources are not sufficient to cover the activities of all the structures. In fact, agencies in charge of monitoring and evaluation are generally not well equipped and/or do not have the appropriate equipment. The financial resources necessary for the implementation of activities are not always adequate.

The other problems identified are the inexistence of a legal framework for monitoring and evaluation units within some ministries on one hand, and the lack of linkage between monitoring 
and evaluation units within sector ministries and the Technical Support Team for Budgetary Reform (ETARB) on the other, especially the training process on program budget, output gathering and management for all monitoring and evaluation activities.

In view of all these difficulties, it is important to strengthen structures responsible for monitoring and evaluation by placing at their disposal the necessary material, human and financial resources to enable them carry out their duties effectively. The most pressing need is to establish such structures in all ministries and clarify their legal status.

\subsubsection{National level}

Most of the PRSP monitoring and evaluation activities were related to the establishment of an effective system of monitoring and evaluation. A program for strengthening the Observatory of Social Change ${ }^{7}$ (PROCS) was set up with the support of development partners.

The inception phase of the program, which started in November 2002, continued till April 2003 thanks to a provisional financial support from donors. All activities planned in respect of the provisional support were implemented by holding on $6^{\text {th }}$ and $7^{\text {th }}$ March a seminar on revamping the Observatory of Social Change (OCS). During the workshop, which was attended by all functional units and development partners, some documents were prepared and validated, including the following:

- $\quad$ Three-year work plan for the OCS;

- $\quad$ Proposal on a system of indicators for monitoring and evaluation of poverty trends and results/impact of the Poverty Reduction Strategy;

- $\quad$ Proposal of some studies to assess the impact of some reforms and initiatives on poverty;

- $\quad$ Reflections on the improvement of follow-up surveys on households.

It should be noted that at the level of the OCS, monitoring and evaluation of the PRSP is done through functional units and structures involved, with their activities being coordinated by the Permanent Secretariat of the National Commission for Development and the Fight Against Poverty through OCS.

The overall objective is to ultimately have in place an adequate national system that can assess periodically, the extent, depth and trends of poverty as well as the relevance, effectiveness, efficiency and sustainability of actions taken within the framework of the PRS. In other words, the system will not only contribute to a better knowledge of the living conditions of the people but also help appreciate the results and impact of development policies, programs and projects implemented under the PRS in relation to the social cultural, economic, political and geographical environment of the country.

The results that one can expect from such a system are as follows:

\footnotetext{
${ }^{7}$ This document the new structure of the OCS comprising four components which are the functional units, to which the strengthening of the CNDLP/PS and the Coordination \& Management of the Observatory of Social Change.
} 
- A permanent and efficient information system on poverty reduction will be in place;

- A database for a better monitoring of economic, financial, social indicators will be set up;

- $\quad$ Specific studies on the issue of poverty and human development will be conducted and published periodically;

- $\quad$ The implementation status of measures stated in the PRSP will be known on annual basis and corrective actions proposed when necessary.

- $\quad$ Specific impact assessment studies of policies, programs, and projects will be conducted and published;

- A framework for consultations between the various actors (state institutions, civil society, private sector, etc.) will be in place;

- $\quad$ National capacity for monitoring and evaluating economic and social policies and strategies will be reinforced.

It is worth noting that after the preliminary start-up phase, a ten-month pilot project under the OCS Capacity building program was defined with financial support from three donors that wanted to use the technical monitoring arrangement through OCS to monitor the PRSP. This pilot phase actually began in December 2003.

Besides, in accordance with the institutional framework described earlier on, the Chairman of the CNDLP set up some regional committees on poverty reduction.

\subsubsection{Action plan for monitoring and evaluation activities}

Table 3.2.1: Action plan for ministries' monitoring and evaluation activities in $20004-2005$

\begin{tabular}{|c|c|c|c|c|c|}
\hline $\mathbf{N}^{\circ}$ & Diagnosis & Objectives & $\begin{array}{l}\text { Expected } \\
\text { results }\end{array}$ & Actions/measures & Actors \\
\hline 1 & $\begin{array}{l}\text { Establishment of monitoring } \\
\text { and evaluation units are } \\
\text { incomplete }\end{array}$ & $\begin{array}{l}\text { Establish } \\
\text { monitoring and } \\
\text { evaluation units } \\
\text { that have a legal } \\
\text { status and all the } \\
\text { components (focal } \\
\text { points) }\end{array}$ & $\begin{array}{l}\text { Availability of } \\
\text { monitoring and } \\
\text { evaluation units } \\
\text { with all the } \\
\text { components }\end{array}$ & $\begin{array}{l}\text { Identify ministries } \\
\text { where they are } \\
\text { non existent or } \\
\text { partially } \\
\text { established, } \\
\text { Provide } \\
\text { monitoring and } \\
\text { evaluation units } \\
\text { with a legal status } \\
\text { and the necessary } \\
\text { focal points }\end{array}$ & $\begin{array}{l}\text { DPP of all } \\
\text { ministries } \\
\text { ETARB/DGB } \\
\text { CNDLP/PS } \\
\text { OCS }\end{array}$ \\
\hline 2 & $\begin{array}{l}\text { Weak of functional link } \\
\text { between monitoring and } \\
\text { evaluation units and ETARB } \\
\text { under DGB }\end{array}$ & $\begin{array}{l}\text { Identify } \\
\text { constraints to the } \\
\text { structural relations } \\
\text { between } \\
\text { monitoring and } \\
\text { evaluation units } \\
\text { and ETARB and } \\
\text { if necessary } \\
\text { propose some } \\
\text { solutions }\end{array}$ & $\begin{array}{l}\text { Diagnosis of } \\
\text { monitoring and } \\
\text { evaluation unit/ } \\
\text { ETARB } \\
\text { relations carried } \\
\text { out and issues } \\
\text { resolved }\end{array}$ & $\begin{array}{l}\text { Organize } \\
\text { consultations } \\
\text { between M\&E } \\
\text { units and ETARB } \\
\text { to clarify links } \\
\text { that should exist } \\
\text { Propose actions } \\
\text { for a better } \\
\text { coordination of } \\
\text { monitoring and } \\
\text { evaluation }\end{array}$ & $\begin{array}{l}\text { DPP of all } \\
\text { ministries } \\
\text { ETARB/DGB } \\
\text { CNDLP/PS } \\
\text { OCS }\end{array}$ \\
\hline
\end{tabular}




\begin{tabular}{|c|c|c|c|c|c|}
\hline $\mathbf{N}^{\circ}$ & Diagnosis & Objectives & $\begin{array}{l}\text { Expected } \\
\text { results }\end{array}$ & Actions/measures & Actors \\
\hline & & & & activities & \\
\hline 3 & $\begin{array}{l}\text { Inadequate capacity of M\&E } \\
\text { units to carry out M\&E } \\
\text { activities during the } \\
\text { implementation of the PRSP }\end{array}$ & $\begin{array}{l}\text { Capacity building } \\
\text { for M\&E units }\end{array}$ & $\begin{array}{l}\text { Functional } \\
\text { M\&E units and } \\
\text { capable of } \\
\text { carrying out } \\
\text { M\&E activities } \\
\text { during the } \\
\text { implementation } \\
\text { of PRSP }\end{array}$ & $\begin{array}{l}\text { Recruit and train } \\
\text { personnel for the } \\
\text { units in data } \\
\text { collection and } \\
\text { analysis as well as } \\
\text { planning } \\
\text { Ensure in-service } \\
\text { training } \\
\text { Train focal points } \\
\text { in the use of M\&E } \\
\text { tools } \\
\text { Provide M\&E } \\
\text { units with } \\
\text { adequate material } \\
\text { and financial } \\
\text { resources }\end{array}$ & $\begin{array}{l}\begin{array}{l}\text { DPP of all } \\
\text { ministries }\end{array} \\
\text { ETARB/DGB } \\
\text { CNDLP/PS } \\
\text { OCS }\end{array}$ \\
\hline
\end{tabular}

\subsection{4 - 2005 ACTION PLAN ON STRENTHENING INFORMATION SYSTEMS FOR PRSP MONITORING AND EVALUATION}

The establishment of an efficient information system for monitoring and evaluating the PRSP implementation process is one of the prerequisites for the success of programs that will be implemented within the framework of the poverty reduction strategy.

The OCS is a national agency organized as a network of functional units made up of various structures responsible for data collection and analysis, especially on poverty and household living conditions. Structures that were in existence before the implementation of the PRSP are the only ones functioning currently.

Various actions have been planned for 2004 and 2005 to strengthen the information system. These actions are broken down into the following components:

Component 1: Capacity Building for management and analysis of macroeconomic data and social indicators.

Through the System of Collection and Analysis of Aggregate Indicators, the DGAE and related structures (IINSAE, BCEAO and ST/CNSAPAS) will be strengthened in terms of analyzing macroeconomic data and social indicators to ensure the analysis of the implications of various macroeconomic frameworks for government budgetary resources and their effects on poverty reduction programs.

The DGAE has planned to redefine and update the database containing the major macro-economic and social indicators from secondary sources. This update will be done by reviewing macroeconomic indicators and debt sustainability ratios and integrating data used by other national institutions that are relevant for the macroeconomic environment analysis; identifying relevant macroeconomic and social indicators relevant for poverty analysis; designing a database 
and drawing up procedures for management and updating of macroeconomic and social indicators.

The DGAE will be responsible for preparing a poverty analysis plan based on aggregate data; the production of a document on "Assessment and Short Term Prospects of the National Economy (BIPEN) over the period 2004 - 2006.

DGAE will:

- Analyze the Government's room to maneuver within the budget using a macro financial project model depending on the various scenarios. It will also develop a module for "Public Expenditure per sector" based on a macro financial project model and determine various macroeconomic framework scenarios as well as simulate their effects on Government's budgetary resource;

- $\quad$ Perform budgetary simulations of poverty reduction objectives and their implications in terms of financial resources using a financial simulation model. The sub activities planned to this effect are as follows:

- Develop a cost matrix that will facilitate financial simulations and analyze the budgetary implications of various scenarios of poverty reduction;

- Compile a database comprising technical coefficient used in the financial simulation model.

INSAE will contribute to activities under this component by:

-Compiling, processing and publishing data on national accounts (DSEE);

-Producing and publishing a Social Blueprint

- Conducting price survey and computing consumer price indices.

BCEAO will compile, process and publish monetary statistics and prepare balance of payments and the ST/CNSAPAS will be responsible for compiling, processing and publishing statistics on public finances, especially, the Statement on State Financial Operations.

Component 2: National Capacity Building in compiling and analyzing data on household living conditions and poverty.

The household survey system should facilitate access to qualitative and quantitative information on living conditions of household and poverty. It is a necessary capacity building tool for structures such as INSAE, MAEP and Employment and Training Observatory (OEF).

A baseline national integrated survey to draw up a national profile on poverty and provide useful information for PRSP monitoring is planned for 2005 - 2006. It will be a World Bank LSMS type of survey, and 1-2 -3 survey type developed by DIAL. Annual follow up survey on household 
survey will be of QUIBB type and will be conducted on reduced sub-sample of households in order to obtain quick results and facilitate panel analysis of poverty trends in Benin.

\section{Component 3: National Capacity building in monitoring implementation}

Performance monitoring is a continuous or periodic review of the implementation of program budgets in order to determine progress made in program delivery, identify difficulties and problems and/or recommend solutions.

Under this component, the General Budget Directorate will monitor the performance of program budgets through the Monitoring and Evaluation Unit of sector ministries. It will therefore be possible to monitor program implementation and ensure a correlation between activities, results obtained and objectives set in the programs on one hand, and result as well as impact indicators from the Poverty Reduction Program. This will also involve capacity building in planning, budgeting, monitoring and evaluation of the performance of M\&E units of sector ministries involved in the implementation of the poverty reduction strategy. Besides, it will build the capacity of institution responsible for providing assistance and implementing M\&E reforms.

There are plans to conduct surveys aimed at constituting a database, clarifying M\&E concepts and defining tasks related to $\mathrm{M} \& \mathrm{E}$ within ministries involved in PERAC.

Component 4: Building National Capacity in impact assessment of poverty reduction policies and interventions.

National capacities in impact assessment of poverty reduction policies programs and projects will be improved. Within this framework, teams external to the government (private research firms, NGOs, university students) will be involved the in the impact assessment of poverty reduction policies and programs. CAPE will be responsible for the drafting of the terms of reference for impact assessment studies, identification of external firms and non-governmental organizations and the selection of external teams that will be entrusted with the impact assessment studies and agree on evaluation methods with organizations selected.

Qualitative and quantitative impact assessment methodologies for poverty reduction policies, programs and projects will be developed. An impact assessment of a social policy is also envisaged. In the same vein, there will be an improvement in national capacities through macroeconomic policies evaluation activities and monitoring the impact of policies programs and projects using qualitative survey techniques. This activity aims at decentralizing the monitoring and evaluation of poverty reduction policies, programs and projects whilst paying particular attention to the gender dimension. The local impact of poverty reduction policies, programs and projects will be assessed in collaboration with mayors, CDS, DDPDs of MCPPD, decentralized departmental services and representatives of civil society organizations. 


\subsection{HUMAN AND MATERIAL CAPACITY BUILDING PLAN FOR PRSP MONITORING AND EVALUATION IN 2004 AND 2005}

Within the framework of human capacity building and the Observatory of Social Improvement Program, there are plans to organize training, (both in Benin and abroad) technical support and study tours for the benefit of officials who will be working on PRSP monitoring and evaluation in 2004 and 2005. In addition, the methodology applicable to all activities to be implemented by the various components of the OCS will be based on the principle of "learning by doing" for all officials. Finally, human capacity building will also be achieved through national and international technical assistance.

Concerning material capacity building, there are plans to:

- $\quad$ Equip (offices and computers) the Management and Coordination Unit of the OCS program and the CNDLP Permanent Secretariat;

- Acquire one vehicle for the Management and Coordination Unit of the OCS Improvement program;

- Provide institutional support to the various functional units involved in the implementation of the OCS Enhancement Program.

- Install Internet and Intranet network, put in place a documentation fund, acquire computers and MS Project software for the Technical Support Secretariat for Budgetary Reform.

What remains to be done is to provide PERAC ministries and statistical divisions within sector ministries with computers, and to train staff in data collection, processing analysis and monitoring.

To improve M\&E indicators for the PRSP implementation process, the Management and Coordination Unit of OCS will support in 2004 and 2005 baseline studies for indentifying and developing relevant indicators for monitoring the four PRSP strategic axes.

\subsection{AND 2005 ACTION PLAN FOR POPULARISING THE PRSP AND PROGRESS REPORT ON PRSP IMPLEMENTATION}

The popularization will be done at two levels:

- At the central level in government institutions and sector ministries through the presentation of PRSP actions and indicators as well as briefings on annual report on the implementation of the PRSP;

- $\quad$ At the departmental level, through multi-sectoral workshops involving government institutions civil society, women's associations, producers' associations and the private sector.

The workshops will be organized as follows: 
- $\quad$ Presentation of PRSP actions based on sector of activity or objective;

- $\quad$ Presentation of activities of each sectors (by officials of this sector);

- $\quad$ Presentation of a PRSP implementation report at the end of 2003 (by CNDLP/PS);

- Presentation of constraints, expectations and suggestions for (i) a better implementation of actions contained in the PRSP, and (ii) an improvement in subsequent years.

- The action plan for the popularization of PRSP and dissemination of the implementation report is presented below:

Action plan for the popularization of the PRSP and implementation report for the period $2004-2005$

\begin{tabular}{|c|c|c|c|c|c|}
\hline Actions & Time & \begin{tabular}{|l|}
$\begin{array}{l}\text { Participating } \\
\text { structures }\end{array}$ \\
\end{tabular} & \begin{tabular}{|l|} 
Structures \\
responsible
\end{tabular} & Content of actions & Observations \\
\hline \multicolumn{6}{|l|}{$\begin{array}{c}\text { I - At the central } \\
\text { level }\end{array}$} \\
\hline $\begin{array}{l}\text { Presentation of the PRSP } \\
\text { in all ministries. } \\
\text { Presentation of the } \\
\text { report at the end of } \\
\text { December } 2003\end{array}$ & February & $\begin{array}{l}\text { DPP, M\&E } \\
\text { units- , officials } \\
\text { of } \\
\text { decentralized } \\
\text { departments } \\
\text { Project/Head } \\
\text { TARB/ MFEP, } \\
\text { etc. }\end{array}$ & CNDLP/PS & $\begin{array}{l}\text { Presentation of } \\
\text { actions planned under } \\
\text { the PRSP and } \\
\text { indicators } \\
\text { Presentation of results } \\
\text { at the end of Dec. }\end{array}$ & $\begin{array}{l}\text { In } 2004 \text { the two } \\
\text { actions will be } \\
\text { combined and } \\
\text { executed in July } \\
2004 .\end{array}$ \\
\hline $\begin{array}{l}\text { Presentation of the PRSP } \\
\text { in the institutions of the } \\
\text { Republic (constitutional } \\
\text { court, Parliament, } \\
\text { Economic and social } \\
\text { council etc.) }\end{array}$ & February & $\begin{array}{l}\text { Members of the } \\
\text { institutions } \\
\text { CNDLP/PS, } \\
\text { OCS, etc. }\end{array}$ & CNDLP/PS & & $\begin{array}{l}\text { In } 2004 \text { the two } \\
\text { actions will be } \\
\text { combined and } \\
\text { executed in July } \\
2004 .\end{array}$ \\
\hline $\begin{array}{l}\text { Presentation of the } \\
\text { implementation report at } \\
\text { the en of December }\end{array}$ & July & & & & \\
\hline $\begin{array}{l}\text { Official seminar on the } \\
\text { PRSP and } \\
\text { implementation report at } \\
\text { the end of Dec. } 2003\end{array}$ & May & $\begin{array}{l}\text { Members of } \\
\text { government, } \\
\text { CNDLP/PS }\end{array}$ & & $\begin{array}{l}\text { Presentation of the } \\
\text { PRSP and } \\
\text { implementation } \\
\text { report at the end of } \\
\text { Dec. } 2003 \\
\end{array}$ & \\
\hline $\begin{array}{l}\text { Organization of debates } \\
\text { on TV and radio on the } \\
\text { PRSP and the } \\
\text { implementation report at } \\
\text { the end of December. }\end{array}$ & $\begin{array}{l}\text { Permanent } \\
\text { task }\end{array}$ & & & $\begin{array}{l}\text { Presentation of the } \\
\text { PRSP (institutional } \\
\text { framework, M\&E, } \\
\text { expected results) } \\
\text { Presentation of the } \\
\text { implementation } \\
\text { report at the end of } \\
\text { Dec. } 2003\end{array}$ & $\begin{array}{l}\text { This action will } \\
\text { be intensified in } \\
\text { April and } \\
\text { August }\end{array}$ \\
\hline \multicolumn{6}{|l|}{$\begin{array}{l}\text { II - At the departmental } \\
\text { level }\end{array}$} \\
\hline $\begin{array}{l}\text { Organization of a } \\
\text { workshop in three } \\
\text { district capital of the } \\
\text { region }\end{array}$ & $\begin{array}{l}\text { 15th May } \\
\text { au } \\
\text { 30th May }\end{array}$ & $\begin{array}{l}\text { Departmental } \\
\text { monitoring } \\
\text { Comm.(CDS), } \\
\text { DPP et and } \\
\end{array}$ & $\begin{array}{l}\text { CNDLP/PS } \\
\text { CDS }\end{array}$ & $\begin{array}{l}\text { 1st Day } \\
\text { Multi-sectoral } \\
\text { Workshop (MEHU, } \\
\text { MTPT, MMEH, }\end{array}$ & \\
\hline
\end{tabular}




\begin{tabular}{|c|c|c|c|}
\hline $\begin{array}{l}\text { (Presentation of the } \\
\text { PRPS and a draft } \\
\text { implementation report } \\
\text { at the end of December }\end{array}$ & $\begin{array}{l}\text { (04 per } \\
\text { district } \\
\text { capital) }\end{array}$ & $\begin{array}{l}\text { Heads of } \\
\text { decentralized } \\
\text { divisions of } \\
\text { sector } \\
\text { ministries, } \\
\text { private sector, } \\
\text { producers' } \\
\text { associations, } \\
\text { civil society, } \\
\text { etc }\end{array}$ & $\begin{array}{l}\text { MCPTN, MSP, etc.) } \\
\text { for issues of } \\
\text { community health, } \\
\text { basic infrastructure; } \\
\text { environmental } \\
\text { management } \\
\\
2^{\text {nd }} \text { Day } \\
\text { Multi-sectoral } \\
\text { workshop (MEPS, } \\
\text { METFP, MESRS, } \\
\text { MFPSS, MFPTRA, } \\
\text { etc.) for issues related } \\
\text { to education and } \\
\text { professional training } \\
\text { 3rd Day } \\
\text { Mult-isectoral } \\
\text { workshop (MISD, } \\
\text { MDN, MJLDH, } \\
\text { MFPTRA, MFE, } \\
\text { HAAC and other } \\
\text { institutions for issues } \\
\text { related to security, } \\
\text { strengthening good } \\
\text { governance and } \\
\text { institutional capacity } \\
\text { building, including } \\
\text { administrative } \\
\text { reforms, budget } \\
\text { management and } \\
\text { decentralization } \\
\text { 4th Day } \\
\text { Multi-sectoral } \\
\text { workshop for } \\
\text { (MAEP, MICPE, } \\
\text { MCAT, MFPSS, } \\
\text { MCPPD, MSP for } \\
\text { issues related to } \\
\text { promotion of } \\
\text { community } \\
\text { development, micro } \\
\text { finance, sustainable } \\
\text { employment income } \\
\text { generating activities } \\
\text { and gender approach. }\end{array}$ \\
\hline
\end{tabular}




\section{BOX 4}

\section{ACTIONS IMPLEMENTED UNDER THE PRSP IMPROVEMENT PLAN}

Concerning deepening the diagnosis of poverty, in accordance with the agreed plan, INSAE, thanks to the OCS enhancement program, organized a workshop on household survey methodology in March 2004. At the end of the workshop, it was agreed that an integrated modular survey on household living conditions be conducted ( a survey with several module which will be conducted using the same methodology simultaneously in both urban and rural areas). The survey will be organized every five years and in between the baseline surveys, there will light integrated surveys every year. Materials for the integrated modular survey have been prepared and validated by INSAE, and a finalization pilot survey will be conducted by February 2005.

A QUIBB survey scheduled for 2003 -2004: Besides the QUIBB survey conducted in 2003 it was not possible to carry out another between 2003 and 2004.

Impact assessment study of reforms in the agricultural sectors particularly, the cotton sub sector on trends in peasant farmers' income. In view of the implementation of a pilot phase of the OCS improvement program that was being finalized by DANIDA, Swiss Cooperation and GTZ between November 2003 and February 2005, it was not possible to conduct an impact assessment study on reforms in the agricultural sector particularly, the cotton sub sector on trends in peasant farmers' income. This study will be conducted in the triennial phase of the capacity building program in monitoring and evaluation, the work plan of which will be validated by February 2005.

Monitoring and Evaluation indicators: During the preparation of the first progress report on the implementation of the PRSP, 33 indicators were retained. This list should be improved for the 2004 and 2005 reports, hence the need to conduct primary surveys to identify and document performance indicators.

Monitoring and Evaluation: Thanks to the pilot phase of the OCS Revamping program, the OCS is currently functional and visible. By February 2005 a diagnostic workshop will be organized for Monitoring \& Evaluation Units to enable them play fully their roles.

Participatory process: Within the implementation framework of the OCS revamping pilot program, a Participatory Local Impact Monitoring Methodology (SILP) was retained and is being experimented in the educational sector in five villages of the Atacora department.

Short-term expenditure framework (CDMT): There has been some improvement in its preparation thanks to recommendations from the PRSP review carried out by the IMF and the World Bank. Besides, there are plans to make the approach used in its preparation more formal and operational.

Institutional framework: Decree no 2004-082 of February 2004 on the powers, composition and functions of the National Commission for Development and the Fight Against Poverty clarifies the institutional framework for monitoring and evaluation of the implementation of the PRSP. The Ministerial Decisions of October 2004 also clarifies the prerogatives of the two technical units of the CNDLP, which are the CNDLP/PS and the OCS. 


\section{CONCLUSIONS AND RECOMMENDATIONS}

There were constraints in analyzing the indicators used for this first progress report on the PRSP as timely data was not available, especially pertaining to poverty and human development.

Poverty trends recorded since 2001 and 1999-2000 show that there has not been any significant progress in spite of improvements certain indicators. Consequently, by most indicators, Benin is way off the targets for the Millennium Development Goals (MDGs). This could be attributed, in part, to the fact that during the first year of implementation there was a downturn in economic activity (an economic growth rate of $3.9 \%$ ).

The level of the PRSP implementation matrix of measures is also below average. Among the reasons for non-implementation of some measures is the lack of institutional ownership of the PRSP, especially by entities responsible for structural reforms, such as privatization and acceleration of administrative reforms.

This document reports only on the implementation stage of the PRSP and could therefore not effectively analyze the impact of various policies or measures implemented during 2003 under the Poverty Reduction Strategy. On the other hand, it has drawn attention to how the indicators are evolving in relation to projected targets for 2003 and particularly for 2015 as far as MDGs are concerned. The report also contributes to the updating of the 2003 - 2005 PRSP in that it addresses the shortcomings (non-availability of statistics in real time) of statistical services of the countries. These services need to be strengthened to provide data on a regular basis so that antipoverty programs can be monitored and evaluated.

As indicated in the monitoring and evaluation guide for PRSP implementation, there is a need to broaden the base of indicators to be monitored during 2004 and 2005. It is therefore necessary to build the capacity to identify and develop all relevant indicators.

While awaiting commitments from all those involved in the implementation of the PRSP, it is recommended that:

- $\quad$ All economic reforms initiated must be pursued and reinforced;

- $\quad$ Program budget preparation practices should be extended to all ministries;

- $\quad$ There should be capacity building for sector ministries and structures responsible for primary and secondary data collection for the identification and development of relevant indicators capable of evaluating the implementation of various measures contained in the PRSP;

- $\quad$ The decentralization process must be pursued and a solution found for the problem of transfer of authority and capacity building for elected local representatives; and

- The PRSP must be disseminated to ensure broad ownership of the various strategies by the services and structures concerned to facilitate implementation of the matrix of measures.

During provincial workshops held to validate this report, the following recommendations were made: 
- Disseminate in local languages the major outlines of the PRSP and the level of implementation;

- $\quad$ Take into account District Development Programs (PDC) during the drawing up of the next PRSP for 2006-2008;

- Schedule the period of compilation of report of the various ministries on the level of implementation of their program of action within the framework of poverty reduction;

- Establish a more rigorous and transparent mechanism for monitoring the privatization of state enterprises;

- Create a structure at the level of the prefectures to be responsible for monitoring alongside the Departmental (Provincial) Monitoring Committee;

- Convert two-thirds of general secondary schools into technical colleges in order to train the manpower required for development;

- $\quad$ Reorient reforms in the civil service especially those concerning putting personnel on contract in the civil service;

- $\quad$ Speed up measures on providing security for vulnerable areas and land reforms;

- $\quad$ Pursue measures aimed at retaining girls in schools by reopening or building boarding schools for girls;

- $\quad$ Promote the mechanization of agriculture and the settlement of producers to avoid land and environmental problems;

- $\quad$ Establish laboratories for product for internal consumption and exports;

- $\quad$ Lighten the report by allowing each province or even districts to have their report on the implementation of the PRS. This will help monitor actions. 
Overall DSRP objectives:

1. Incidence of monetary poverty (area, Department)

Human poverty Index (IPH-1)

Axis 1. Strengthening medium term macro economic framework

$2 . \quad$ Real economic growth rate (sector)

3. Inflation rate

4. Real GDP growth rate per capita

5. Overall deficit (payments excluding grants) in \% GDP

6. Balance of trade (Excluding re-exportation ) in \% GDP

Debt servicing in percentage of exports

Axis 2 Human capital development and environmental management

Health:

7. Infant mortality rate (IMR) (area, gender, department)

8. $\quad$ Child mortality rate (TMM5) (area, gender, department)

9. Maternal mortality rate (milieu, department)

10. HIV-AIDS prevalence rate among pregnant women during antenatal visits to the Health centre (area, department.)

11. Rate of malaria risk per 1000 inhabitants (milieu, gender, district)

12. Rate of malnourished children aged 0-5 (retardation of growth and emaciation) (milieu, gender, department)

13. Incidence of nutritional poverty (milieu, department)

14. Literacy rate (area, gender, department)

15. Gross rate of enrolment in school (area, gender, department)

16. Rate of children having completed primary school (area, gender, department)

Sanitation, energy and natural environment

17. Percentage of people with access to potable water (area, department)

18. Percentage of homes with latrines (area, department)

19. Number of households with access to public sources of electricity (area, department)

Rate of deforestation due to uncontrolled bush fires (department)

Axis 3. Building institutional capacity and good governance

20. Rate of execution of budgeted recurrent expenditures, excluding salaries in PERAC ministries salaries

21. Rate of execution of budgeted capital expenditure of PERAC ministries

22. Average time frame for award of procurement contract (type of procurement, ministry)

23. Average time frame the payment of public expenditure (type of market, ministry)

24. Percentage of public expenditure that actually goes to priority sectors

( investment and operation)

25. Share of state budget actually transferred to local authorities

Women's participation index

Axis 4. Management of mutual support groups and building capacity of poor communities to participate in the production and decision making process

26. Percentage of communities covered by a community development plan.

27. Percentage of communities covered by a community development program.

28. Rate of penetration of decentralized financial department.

29. Percentage of total number of inaccessible communities during the rainy season.

Note: $\quad$ Milieu: Rural/Urban; gender: men/women and boys/girls, sector: primary/secondary/tertiary Type of market; supplies/services and small /large enterprises. 


\section{Appendix 2: Definition of indicators retained}

\section{Overall PRSP objectives}

- Indicator 1. Incidence of monetary poverty: This is a standard criteria used to distinguish poor homes from non-poor ones based on the poverty line. This represents the percentage of poor people in the society. This is usually calculated based on real consumer spending per adult. During the analysis, the difference in percentage in 2003 will be calculated based on the measures necessary to achieve the MDG1 target by 2015 and thus ascertain whether Benin is moving towards the set target.

- Indicator 2: Human Poverty index (IPH1): This is a composite index used in assessing deprivation in three vital aspects of human life (as discussed in the Human Development index). The IPH 1 stresses on shortcomings in three fundamental aspects:

○ Long life and good health: the risk of dying at a relatively younger age shown by the probability, at birth, of not attaining age 40 .

- Acquire training and education: exclusion from the world of reading and communication, expressed in terms of illiteracy rate.

○ Descent life: inability to have access to what the economy provides as expressed by the percentage of people deprived of access to water supply and by the percentage of underweight children below the age of 5. This overall indicator has the advantage of giving a multi-dimensional view of monetary and non-monetary poverty. This is an index that is calculated for all developing countries and it allows international comparisons.

Axis 1: Strengthening the medium term macro-economic framework.

- Indicator 3: Real economic growth rate: This is an indicator for the creation of added value by the economic operators and the private sector among other things. Since it is broken down on sector basis, this indicator allows for an assessment as to whether the productive sectors are growing. It also indicates the trends in GDP over a two-year period. It helps assess the growth observed at the level of this index. The current GDP growth rate is referred to as the economic growth rate. This is generally the indicator applied in international comparisons. The real GDP growth rate (by eliminating price effect) refers to actual growth. In both cases there is the possibility of dividing the GDP by the population to obtain the GDP per capita so as to ascertain the growth rate per head.

- Indicator 4: Rate of inflation. This refers to a measure of stability in the macro-economic framework and purchasing power of businesses and households. It shows the relative variations in the consumer price index between a month of a given year and the same month of a previous year. A price index is the overall figure calculated based on the prices of various goods and services. Its trends reflect price increases within a given sector or in the economy as a whole. Consumer price index deals only with household consumption.

- Indicator 5: Real GDP growth rate per capita: This indicator helps assess to what extent the creation of added value is growing faster that the population growth and results in the improvement of the average standard of living standard of the individual. This is obtained by dividing the real GDP by the population. 
- Indicator 6: Overall deficit (payments excluding grants) in \% GDP. This indicator implies a substantial macro-economic balance, which serves as guarantee for sustainable growth and the capacity to finance public services.

- Indicator 7: Trade balance (excluding re-exportation) in \% GDP. This index implies an external trade balance with regard to goods and services and therefore indicates Benin's ability to finance its importations.

- Indicator 8: Debt servicing in \% exports: This indicator shows whether the country is able to repay its debts without mortgaging its export earnings. Reducing the debt burden to manageable levels is also tied to target 13 and 15 of the MDG 8 in terms of the global partnership for development.

\section{Axis 2: Human Capital Development and Environmental Management:}

\section{Health}

- Indicator 9: Infant mortality rate (known as IMR) This indicator measures the seriousness of the health problems facing a particularly vulnerable target group, which are children below one. It is the report in a given year of the number of children who die before their first birthday: thus the probability, of a child dieing before his first birthday out of 1000 safe deliveries.

- Indicator 10: Child mortality rate (referred to as CMR5). This indicator is as important as the previous one and covers a larger target group of children below 5 years. This refers to the number of children below 5 who die irrespective of the cause. This is in other words the probability of children dying before their fifth birthday from any sickness, out of 1000 safe births. During the analysis, the difference in percentage in 2003 will be calculated based on the measures necessary to achieve the MDG4 target by 2015 and thus ascertain whether Benin is moving towards the set target.

- Indicator 11: Maternal mortality rate: This indicator refers to another vulnerable group of women of child-bearing age (15-49 years). Maternal death refers to the death of a woman during pregnancy or within 42 days after childbirth be it during pregnancy by whichever complication caused or aggravated by the pregnancy. Deaths due to accident are not taken into consideration. Maternal mortality rate is the number maternal deaths per 1000 expectant births. This can be raised to 100,000 births depending on the needs of the analysis.

- Indicator 12: HIV-AIDS prevalence rate among pregnant women during antenatal visits to the health centre. This is the percentage of HIV-AIDS infected women who go for antenatal care as per the total number of pregnant women who need antenatal care. This indicator gives an insight into the HIV prevalence rate in the society and is easy to obtain. During the analysis, the difference in percentage in 2003 will be calculated based on the measures necessary to achieve the MDG6 target by 2015 and thus ascertain whether Benin is moving towards the set target. 
- Indicator 13: Malaria lethality rate per 1000 inhabitants: This indicator refers to one of the deadliest endemic diseases in Benin. The malaria lethality rate measures the probability of death among those who develop malaria. This is also an MDG6 indicator.

\section{Nutrition:}

- Indicator 14: Percentage of malnourished children below 5 (coupled with retardation of growth and emaciation) The malnutrition indicator needs to be looked at critically. Adequate nutrition is a basic necessity. It is further included in the Second part of the MDG1. Even though Benin's infant and infant-child mortality rates are not as high as those of other countries, malnutrition remains a serious problem in terms of retardation of growth which affects the child's physical and mental condition and emaciation due to poor economic conditions.

- Indicator 15: Incidence of nutritional poverty. This is the criterion used to categorize households according to their capacity to cover nutritional expenses (nutritional poverty line). During the analysis, the difference in percentage in 2003 will be calculated based on the measures necessary to achieve target 2 of MDG1 by 2015 and thus ascertain whether Benin is moving towards the set target of reducing malnutrition.

\section{Education:}

- Indicator 16: Literacy rate: This indicator gives an overview of the general level of education in the society.

- Indicator 17: Gross rate of enrolment in Primary school rate: This indicator shows the level of access to primary education for children of school going age. This represents the ratio of children supposed to be in school to the actual number of children enrolled. It indicates the number of children newly enrolled in primary schools in relation to the number of children who have the right to be enrolled in schools. In other words, the gross rate of enrolment in primary school represents the total number of new enrolments into first year of primary education irrespective of age, expressed as a percentage of the total number of children who have attained the official primary school admission age.

- Indicator 18: Rate of children having completed the first cycle or primary school completion rate: This indicator measures the ratio of people promoted to primary class 6 to total number of pupils aged 11 . This indicator assesses the capacity of the educational system and parents to provide children with basic education. (During the analysis, the difference in percentage in 2003 will be calculated based on the measures necessary to achieve the MDG2 and MDG3 target by 2015 and thus ascertain whether Benin is moving towards the set target of ensuring primary education and gender equality).

\section{Sanitation, Energy and the Natural environment.}

- Indicator 19: Percentage of people with access to potable water. This indicator refers to a basic need which also ensures good hygiene and health. During the analysis, the difference in percentage in 2003 will be calculated based on the measures necessary to achieve 
target 10 of MDG 7 by 2015 and thus ascertain whether Benin is moving towards the set target of improving access to potable water.

- Indicator 20: Percentage of households with latrines: This indicator reflects the quality of housing as well as sanitation. During the analysis, the difference in percentage in 2003 will be calculated based on the measures necessary to achieve target 11 of MDG 7 by 2015 and thus ascertain whether Benin is moving towards the set target of improving housing in slum areas.

- Indicator 21: Number of households with access to public sources of electricity: This indicator reflects access to modern sources of electricity which helps reduce the drudgery in manual work, improve the living conditions and reduce deforestation caused by the use as charcoal.

- Indicator 22:Rate of deforestation due to bush fires: This indicator measures the extent of damage caused to forests reserves due to uncontrolled bush fires.

\section{Axis 3: Strengthening good governance and institutional capacity building}

- Indicator 23: Rate of execution of budgeted recurrent expenditure excluding salaries of PERAC ministries: This indicator reflects the capacity to absorb and manage financial resources. This is the level of commitment made as at 31 st December in terms of disbursed and non disbursed recurrent expenditure (excluding personnel) of PERAC ministries in relation with to budget projections.

- Indicator 24: Rate of budgetary allocations for PERAC ministries capital expenditure: This indicator reflects the capacity to absorb and manage financial resources. This is the level of commitment made as at 31 st December in terms capital expenditure and financed with state resources in PERAC ministries in relation to budget projections.

- Indicator 25: Average time frame for awarding contracts: This indicator shows the level of efficiency in public procurement.

- Indicator 26: Average time frame for payment of public spending: This indicator is also the standard indicator of efficiency in budget execution.

- Indicator 27: Percentage of actual public spending on priority sectors (investment and operations). This indicator shows the percentage of public expenditure that is actually made in priority areas and whether actual allocations correspond to stated priorities.

- Indicator 28: amount of government budget actually transferred to local groups: This indicator reflects the actual progress made in decentralization.

- Indicator 29: Women's participation index (WPI): This index measures the rate at which women occupy positions of authority and decision-making. It also helps ascertain whether Benin is moving towards MDG3 
- Indicator 23 and 29 partially serve as an assessment of Benin's progress towards target 12 of MDG8 on good governance.

Axis 4: Building solidarity and the capacity of poor communities to participate in the production and decision-making process.

- Indicator 30: Percentage of communities covered by a community development plan: This indicator shows how the planning process at the community level is actually implemented

- Indicator 31: percentage of communities covered by a community development program: This indicator looks at the state's willingness to build capacity at the grass root level through development programmes and projects with the view to equipping them to participate in the development and decision-making processes (communities covered by such programmes are those within the AGeFIB gender programme zone.)

- Indicator 32: Rate of penetration of decentralized financial services. This indicator shows the number of persons benefiting from centralized financial departments, such as the number of clients of micro-finance institutions that enjoy savings or credit facilities.

- Indicator 33: Percentage of communities that become inaccessible during the rainy season: This indicator shows the extent to which rural communities are cut off and lack access to basic social services and markets to buy consumer goods as well as sell their products. 


\section{Appendix 3: Rate of execution of budgeted recurrent expenditure excluding salaries of PERAC ministries for the $2001 / 2003$ period. ( $\%$ )}

\begin{tabular}{lllll} 
Current expenditure (excluding salaries) & 2001 & 2002 & 2003 & Average. \\
\hline Ministry of Justice and Human Rights & 87.2 & 93.2 & 97.5 & 92.6 \\
\hline $\begin{array}{l}\text { Ministry of Agriculture, Livestock } \\
\text { and Fishing }\end{array}$ & 122.8 & 98.8 & 98.3 & 106.7 \\
\hline Ministry of Public Health & 98.5 & 90.1 & 99.9 & 96.2 \\
\hline $\begin{array}{l}\text { Ministry of Environment, Housing } \\
\text { And Town Planning }\end{array}$ & 246.3 & 94.9 & 97.2 & 146.2 \\
\hline Ministry of Mines and Energy & 78.2 & 81.5 & 98.3 & 86.0 \\
\hline Ministry of Works and Transport & 98.4 & 96.9 & 98.9 & 93.1 \\
\hline $\begin{array}{l}\text { Ministry of Industry, Trade and } \\
\text { Employment promotion }\end{array}$ & 90.1 & 91.7 & 98.2 & 93.4 \\
\hline $\begin{array}{l}\text { Ministry for primary and } \\
\text { Secondary education }\end{array}$ & & 91.0 & 97.7 & 94.4 \\
\hline $\begin{array}{l}\text { Ministry of Technical and Professional } \\
\text { Training }\end{array}$ & 103.7 & 91.0 & 98.9 & 94.9 \\
\hline $\begin{array}{l}\text { Ministry for Higher education and } \\
\text { Scientific Research }\end{array}$ & 64.2 & 95.6 & 79.9 \\
\hline Average & 115.7 & 89.3 & 98.1 & 98.8 \\
\hline \hline
\end{tabular}

Source: SIGFIP/ MFE

\section{Appendix 4: Rate of execution of budgeted capital expenditure excluding salaries of PERAC ministries for the $2001 / 2003$ period. ( \%)}

\begin{tabular}{|c|c|c|c|c|}
\hline Capital expenditure & 2002 & 2003 & Average. & \\
\hline Ministry of Justice and Human Rights & 65.00 & 43.97 & 42.43 & 50.47 \\
\hline \multicolumn{5}{|l|}{ Ministry of Agriculture, Livestock } \\
\hline and Fishing & 48.82 & 70.60 & 96.43 & 71.95 \\
\hline Ministry of Public Health & 82.18 & 72.03 & 56.38 & 70.20 \\
\hline \multicolumn{5}{|l|}{ Ministry of Environment, Housing } \\
\hline And Urbanization & 168.46 & 86.70 & 73.19 & 109.45 \\
\hline Ministry of Mines and Energy & 29.54 & 58.76 & 52.22 & 46.84 \\
\hline Ministry of Works and Transport & 127.96 & 78.55 & 77.76 & 94.76 \\
\hline \multicolumn{5}{|l|}{ Ministry of Industry, Trade and } \\
\hline Employment promotion & 209.19 & 76.07 & 61.90 & 115.73 \\
\hline \multicolumn{5}{|l|}{ Ministry for primary and } \\
\hline Secondary education & & 59.66 & 49.28 & 54.47 \\
\hline \multicolumn{5}{|l|}{ Ministry of Technical and Professional } \\
\hline Training & 80.44 & 51.57 & 58.88 & 55.23 \\
\hline \multicolumn{5}{|l|}{ Ministry for Higher education and } \\
\hline$\underline{\text { Scientific research }}$ & & 44,91 & 40.52 & 42.72 \\
\hline Average & 101.45 & 64.28 & 60.909 & 71.18 \\
\hline
\end{tabular}

Source: PIF Executive management report. 2001, 2002 and 2003/ MCPPD/ DGPP 
Appendix 5: Trends in the average time frame for payment of public expenditure (type of expenditure by ministry)

\begin{tabular}{|c|c|c|c|c|c|c|c|c|c|}
\hline \multirow[t]{3}{*}{ Ministry } & \multicolumn{7}{|c|}{ Average time frame achieved. } & \multirow{2}{*}{$\begin{array}{l}\text { Target } \\
\text { value }\end{array}$} & \multirow[t]{3}{*}{ Difference } \\
\hline & \multirow[t]{2}{*}{2001} & \multirow[t]{2}{*}{2002} & \multicolumn{5}{|l|}{2003} & & \\
\hline & & & Operation & $\begin{array}{l}\text { Common } \\
\text { expenditure }\end{array}$ & $\begin{array}{l}\text { BES } \\
\text { A }\end{array}$ & PIP & Moy & 2003 & \\
\hline $\mathrm{MDN}$ & 10.1 & 18 & 29.3 & 0 & 12.6 & 40.2 & 27.4 & 20 & -7.4 \\
\hline MISD & 7.2 & 24.3 & 25.3 & 0 & 17.5 & 25.3 & 22.7 & 20 & -2.7 \\
\hline MAEIA & 27.6 & 61.5 & 26.5 & 0 & 24 & 21.3 & 23.9 & 20 & -3.9 \\
\hline MFE & 27.2 & 24.5 & 16.8 & 22.8 & 16.9 & 20.6 & 19.3 & 20 & 0.7 \\
\hline MJLDH & 27.7 & 22.9 & 19.2 & 0 & 20.9 & 24.6 & 21.6 & 20 & -1.6 \\
\hline MCCPD & 28.3 & 22.1 & 23.7 & 0 & 20.3 & 22.3 & 22.1 & 20 & -2.1 \\
\hline MCRISCBE & 25.1 & 20.2 & 19.4 & 0 & 18.7 & 20.8 & 19.6 & 20 & 0.4 \\
\hline MTPT & 29.1 & 22.4 & 16.5 & 0 & 17.9 & 16.7 & 17 & 20 & 3 \\
\hline MFPTRA & 35.6 & 26.4 & 23.4 & 0 & 17.7 & 26.2 & 22.4 & 20 & -2.4 \\
\hline MCPTN & 27.7 & 16.5 & 16.5 & 0 & 22.3 & 20 & 19.6 & 20 & 0.4 \\
\hline MICPE & 27 & 20.8 & 28.1 & 0 & 20.9 & 17.9 & 22.3 & 20 & -2.3 \\
\hline MEHU & 22.2 & 18.3 & 16.7 & 0 & 14.5 & 17.3 & 16.2 & 20 & 3.8 \\
\hline MSP & 24.1 & 23.2 & 30.2 & 0 & 20.8 & 25.5 & 25.5 & 20 & -55 \\
\hline MMEH & 25.7 & 23.9 & 19.9 & 0 & 12.7 & 21.5 & 18 & 20 & 2 \\
\hline MCAT & 37.2 & 23.8 & 22.9 & 0 & 18.2 & 24.9 & 22 & 20 & -2 \\
\hline MAEP & 30.2 & 22 & 15.2 & 0 & 11.8 & 17.2 & 14.7 & 20 & 5.3 \\
\hline MJSL & 40.5 & 30.2 & 30.8 & 0 & 30.2 & 26.2 & 29.1 & 20 & -9.1 \\
\hline MFPSS & 30.2 & 24.5 & 36 & 0 & 30.4 & 30 & 32.1 & 20 & -12.1 \\
\hline MEPS & 30.4 & 28.9 & 23.6 & 0 & 21.3 & 25.3 & 23.4 & 20 & -3.4 \\
\hline METFP & & 28.7 & 21.4 & 0 & 21.2 & 20.5 & 2.1 & 20 & -1 \\
\hline MESRS & & 28.5 & 21.3 & 0 & 12.1 & 21.7 & 18.4 & 20 & 1.6 \\
\hline Summary & 26 & 24.9 & 23.3 & 22.8 & 21.9 & 22.8 & 22.7 & 20 & -2.7 \\
\hline $\begin{array}{l}\text { General } \\
\text { summary }\end{array}$ & & 24.9 & 22.7 & & & & & 20 & -2.7 \\
\hline
\end{tabular}




\begin{tabular}{||c|c|c|}
\hline MEASURES & DATE & $\begin{array}{c}\text { LEVEL OF } \\
\text { IMPLEMENTATION }\end{array}$ \\
\hline \hline
\end{tabular}

\section{STRENGTHERNING THE MIDIUM TERM MACROECONOMIC FRAMEWORK}

\subsection{Consolidation of the Sources of growth}

a) Agriculture Animal husbandry, fisheries and handicraft production

- To undertake agricultural research and to create conditions that will make seeds, plants and other agricultural inputs available and at low cost.

- To strengthen the capacities of the decentralized funding agencies and improve access to micro credits (of paragraph 229)

- To modernize agriculture (development of lowlands of the town, development of irrigation systems and farming systems.

\section{LAND ISSUES}

- $\quad$ To speed up the drawing up of the rural land plan.
2003-2004

2003-2004

2003-2005 have been carried out through rural development and equipment projects being implemented at the MAEP to develop small-irrigated areas and water resource for agriculture of the departments.

A study on the problems of the seed sector in Benin is planned for March 2004 with Benin/Belgium funding.

In order to improve access to micro credit, credit lines are available for purpose through 02 projects funded by FIDA (PROMIC and PAGER) as well as other projects funded by $\mathrm{ADB} / \mathrm{ADF}$ to supports rural development. Moreover the state supports decentralized funding agencies through the Microfinance and that of the Ministry of Finance and Economy.
Actions geared towards this objective

The privatization process of the SONAPRA industrial units is at the pre-qualification stage of the reference operators or associate groups of the cotton sector. Invitation of expression of interest has been launched and the bids are expected by the end of January 2004. The pilot study of the law has been

Dec. 2005 The pilot study of the law has been submitted to the supreme court for consideration. 
- To have research undertaken to improve the performance of local cattle breeds.
April 2004

Actions are ongoing with regard to :

- research on trypno resistant breeds in Atacora;

- genetic research to improve dairy production in Okpara;

- purification of cattle breeds.

\section{FISHERIES}

- To draw up and implement the fishing code

June 2004

The study on the drawing up of the fishing blueprint law has been undertaken. The process is ongoing for its adoption by the National Assembly before its ownership by stakeholder in the fishing industry

\section{HANDICRAFT}

- To carry out actions to promote local handicraft.

- To promote microfinancing (cf. paragraph 229 PSRP)
2003-2004

The Department for cottage industries organize a National Handicraft exhibition from 28 to 08 December 2003.

2003-2004

The Ministry of Culture, Cottage industries and Tourism organized in July 2003 a meeting to select the microfinancing institution that will be responsible for the management of the 500 million FCFA grant. The beginning of the activities is scheduled for the first quarter of 2004.

\section{SMALL SCALE PROCESSING}

- To establish light processing units for a participatory development of technology
Dec. 2005

. The program started since 1996 and was ongoing in 2004. Production tests continued with quality tests in the laboratories of the (CNERTP and the University). Other actions undertaken were:

- A furnace with a capacity of 30,000 bricks being constructed should be completed in 2004;

- Carving of 880 tons of marble, manufacture of 6,250 bricks, production of 449, 9 tons of granite and conditioning of 5,640 tons of lime paste;

- A fair of about fifteen building materials was organised;

- A documentary film on building materials was produced. 


\begin{tabular}{|c|c|c|}
\hline MEASURES & DATE & $\begin{array}{l}\text { LEVEL OF } \\
\text { IMPLEMENTATION }\end{array}$ \\
\hline \multicolumn{3}{|c|}{ NEW INFORMATION COMMUNICATION TECHNOLOGIES (NICT) } \\
\hline $\begin{array}{l}\text { The draw up the National NICT } \\
\text { development strategy }\end{array}$ & June 2003 & $\begin{array}{l}\text { The national NICT development } \\
\text { strategy document was drawn up and } \\
\text { adopted by the Government in } \\
\text { February } 2003 \text {. } \\
\text { Its implementation started with the } \\
\text { ongoing execution of a number of } \\
\text { projects and programs. }\end{array}$ \\
\hline \multicolumn{3}{|c|}{ PROMOTION OF TRANSIT ACTIVITIES } \\
\hline $\begin{array}{l}\text { To undertake a specific study on this branch } \\
\text { of activity }\end{array}$ & August 2003 & To be implemented \\
\hline \multicolumn{3}{|l|}{ c) Industrial Sector } \\
\hline $\begin{array}{l}\text { - To reactivate and/or create supporting } \\
\text { structures to attract the investments }\end{array}$ & 2003-2004 & $\begin{array}{l}\text { In this context: } \\
- \text { The Consular Assembly was } \\
\text { established; } \\
- \text { The statutes of the chamber } \\
\text { of commerce and industry of } \\
\text { Benin were updated and } \\
\text { approved; }\end{array}$ \\
\hline $\begin{array}{l}\text { - To Implement a program to enhance the } \\
\text { value of local building materials }\end{array}$ & Sept. 2003 & $\begin{array}{l}\text { - The program started since } 1996 \text { and } \\
\text { was ongoing in } 2004 \text {. Production } \\
\text { tests continued with quality tests in } \\
\text { the laboratories of the (CNERTP and } \\
\text { the University). Other actions } \\
\text { undertaken were: } \\
\text { - A furnace with a capacities } \\
\text { of } 30,000 \text { bricks being } \\
\text { constructed should be completed } \\
\text { in } 2004 ; \\
\text { - Carving of } 880 \text { tons of } \\
\text { marble, manufacture of } 6,250 \\
\text { bricks, production of } 449,9 \text { tons } \\
\text { of granite and conditioning of } \\
5640 \text { tons of lime paste; } \\
\text { A fair of about fifteen } \\
\text { building materials was organised; } \\
\text { - A documentary film on } \\
\text { building materials was produced. }\end{array}$ \\
\hline
\end{tabular}


1.2. Strengthening of the basic infrastructures for the available production factors and at reduced costs.

a) Energy, Waster and Mines.

\section{ENERGY}

- To establish a regulatory body

June 2003

- To entrust the management of "Electricity" branch to private operators

April 2003

- To make interconnections between CEB,

2003-2004

NEPA and Northern Togo
The law on the creation, organization and functions of the regulatory body was sent to the Government for submission to the National Assembly. The establishment of the regulatory body was scheduled for December 2004.

A consultant was recruited to assist the Government in the process for fifteen (15) month starting from the signing of the said contract in February 2004. The drawing of the contract was scheduled for the second half of 2005.

. CEB-NEPA interconnection: The firms have already been selected and the Government side has provided funding. The beginning of the project was scheduled for March 2004.

.Northern

Togo-Benin interconnection: its execution depends on the progress of the CEB-NEPA project.

\section{WATER}

- To establish an institution responsible for the management of the water sector

- To construct and/or rehabilitate water reservoirs, micro dams and the agriculture development scheme of Adjarala
Dec. 2003

2003-2004
The National Water Company of Benin was established.

The funding of the water resources development project of Adjarala is in the process of being effected. A donor round table was scheduled for the first quarter of 2004.

\section{MINES}

\begin{tabular}{|l|l|l|}
\hline & & \\
\hline b) Postand tecomancatons & \\
\hline
\end{tabular}

\section{b) Post and telecommunications}

\begin{tabular}{|l|l|l|}
\hline To privatize the telecommunications public operator & July 2003 & $\begin{array}{l}\text { The work that should enable the final } \\
\text { separation of the two entities of Post } \\
\text { and telecommunications are ongoing. } \\
\text { The achievement of the objective is } \\
\text { dependent on the completion of the } \\
\text { ongoing work. }\end{array}$ \\
\hline
\end{tabular}

c) Transport Infrastructure 
- To pursue the activities of the transport sector project

- To pursue the policy of rehabilitation of existing roads
2003-2005

The planned activities are being carried out with funds from the national budget and from NDF

2003-2005

There is a program to rehabilitate existing roads to which a credit has been allocated each year under the PIP.

\section{MARITIME AND PORT TRANSPORT}

- To involve the private sector in the management of the Cotonou Port

- $\quad$ Feasibility study

- $\quad$ Choice of reference operators and the final adoption of a new management method
June 2003

August 2004 of the method of management" has been completed. The $2^{\text {nd }}$ phase on "the feasibility study of the scenario retained" and the $3^{\text {rd }}$ phase on the "implementation of the said scenario" have not started.

\section{AIR TRANSPORT}

- To gradually transform the secondary airfields of Parakou and Natitingou into airports of ICAO international standards

- $\quad$ Feasibility study

- $\quad$ Decision making

- To have a second airport constructed by the private sector on BOT basis

- $\quad$ Feasibility study

- $\quad$ Decision making
Dec. 2003

Feasibility studies on the runways of the Parakou and Natitingou airports are being completed.

June 2005

The decision will be taken at the end of the studies.

August 2003

January 2004
The Glodjigbé site has been retained for the construction of the second airport on BOT basis. The topographic layout works have been completed.

The terms of reference of the environmental, technical and economic feasibility studies have been drawn up for the launching of the international invitations to tender. 


\section{HUMAN CAPITAL DEVELOPMENT AND ENVIRONMENTAL MANAGEMENT}

a) Education

\section{PRIMARY EDUCATION}

- To draw up the list of schools and make an equitable geographical distribution of schools

- To pursue the support program for Communities for enrolment and retention of pupils in school particularly girls
Dec. 2005

Definition of a conceptual framework and the recruitment of a technical assistant. He was responsible for the establishment of an efficient system for collecting processing and dissemination of educational statistics, monitoring and evaluating the activities of the sector dealing with education and the drawing up of the list of schools.

2003-2005

. Construction of classrooms in the schools

. This measure is supported by the establishment and equipment of government and religious groups canteen, the construction of stores for storage of food, training of canteen administrators.

. Production and distribution of 1000 guides on canteen management Formation of a canteen management committee in schools

\section{SECONDARY EDUCATION}

\begin{tabular}{|l|l|l|}
\hline MEASURES & DATE & \multicolumn{1}{|c|}{$\begin{array}{c}\text { LEVEL OF } \\
\text { IMPLEMENTATION }\end{array}$} \\
\hline $\begin{array}{l}\text { - To repair and/or construct classrooms, a } \\
\text { secondary school of excellence, laboratories and } \\
\text { to equip them. }\end{array}$ & $2003-2005$ & $\begin{array}{l}\text { The beginning of the construction of } \\
120 \text { classrooms in 30 General } \\
\text { education colleges. A total of 92 } \\
\text { classrooms built have already been } \\
\text { commissioned, 36 of which have been } \\
\text { equipped. Firms have been recruited } \\
\text { for construction works and the } \\
\text { equipment of 78 laboratories. } \\
\text { The construction of a secondary } \\
\text { school of excellence has been } \\
\text { included in PIP of 2005. }\end{array}$ \\
\hline
\end{tabular}


- To strengthen the educational and 2003-2005 administrative infrastructure of the campus
Several programs have been listed in the 2003 and 2004 PIP for the construction of amphitheatres, classrooms, lecture halls and residences and administrative buildings for the universities of Abomey-Calavi and Parakou.

Most of the works have started.

To draw up research programs and programs for the promotion of international exchanges
Sept. 2005

The national research program is ongoing. It includes sectoral research programs. The strategic development plan for higher education and scientific research aims among other objectives at developing inter university cooperation in the sub region and in the world as well as the establishment of partnership with other institutions..

\section{b) Literacy}

- To construct and equip training centers and produce teaching and reading materials
2003-2005

As part of the component "Promotion of literacy among women", 45 literacy centers are being constructed out of the 100 planned. The contracts for the construction of 55 others are in the process of being signed.

With regard to the design of the teaching and reading materials, workshops for the design and production of the materials were envisaged for 2004. 


\begin{tabular}{|c|c|c|}
\hline MEASURES & DATE & LEVEL OF IMPLEMENTATION \\
\hline $\begin{array}{l}\text { - To reorganize the health system and to } \\
\text { improve health care coverage }\end{array}$ & $2003-2005$ & $\begin{array}{l}\text { The health service has been } \\
\text { strengthened the } \\
\text { construction/rehabilitation of health } \\
\text { centers by means of the PIP and as part } \\
\text { of diverse projects of the Ministry of } \\
\text { Public Health. The national average in } \\
\text { terms of health care coverage in health } \\
\text { centers is currently at } 822 \text {, not } \\
\text { withstanding the weakness noted in } \\
\text { some departments (Littoral, Zou } \\
\text { Collines) and the disparities in the } \\
\text { district hospitals. } \\
\text { The health areas have been } \\
\text { decentralized and the } 34^{\text {th }} \text { health area } \\
\text { was created in } 2003 \text { A technical } \\
\text { adviser was appointed to support the } \\
\text { decentralisation of the health sector. } \\
\text { The texts governing the institutions of } \\
\text { the health area have been updated. } \\
\text { However the hospitals in the areas lack } \\
\text { specialists. }\end{array}$ \\
\hline $\begin{array}{l}\text { To prevent and control diseases and } \\
\text { improve the quality of care (Except STD/ AID) }\end{array}$ & $2003-2005$ & $\begin{array}{l}\text { Bimonthly meetings have been } \\
\text { organized for each department to } \\
\text { report on the process of monitoring } \\
\text { diseases prone to epidemics. An } \\
\text { amount of } 3,796 \text { million FCFA has } \\
\text { been listed in the } 2003 \text { PIP. } \\
\text { The } 8^{\text {th }} \text { National vaccination days } \\
\text { against poliomyelitis were organized in } \\
2003 \text {. } \\
\text { A study was conducted on the state of } \\
\text { the carrier control in Benin. The } \\
\text { training of specialists is underway. } \\
\text { Prevention of malaria through the } \\
\text { reduction of man/vector contact has } \\
\text { been realized through the use of } \\
\text { mosquito nets at subsidized price. } \\
\text { The prevention of mother-child } \\
\text { transmission (PETRAME) has started } \\
\text { in Cotonon and it will be extended to } \\
\text { the entire country. } \\
\text { The care for Persons Living with } \\
\text { HIV/PV/HIV) is only provided in } \\
\text { Atlantique/Littoral and Oueme/Plateau } \\
\text { because of madequate resources. }\end{array}$ \\
\hline
\end{tabular}


- To promote family health

The new strategy called "Integrated care of childhood diseases" PCIME" has been extended to three (03) health areas in Zou. It started with the evaluation of national needs in Emergency Obstetrics Care (SOU).

Likewise, the content of the antenatal visits has been revised in order to reduce maternal mortality. It will be implemented from 2004. The distribution of guides on family health is also envisaged.

d) Potable water

- To let the NGOs organize initial and in-

2003-2005

The activity of organizing initial and depth IEC meetings in all the towns benefiting from the works

- To finalise the resource management

June 2003 in-depth IEC meetings has been transferred to the NGOs by the water works management.

strategy document

The water resource management strategy document has been suspended and the strategy will be integrated in the GIRE.

\begin{tabular}{||l|l|l||}
\hline \multicolumn{1}{|c|}{ MEASURES } & DATE & LEVEL OF IMPLEMENTATION \\
\hline \hline e) Housing
\end{tabular}


- To simplify procedures for the sale of land and landed property while taking into account realities on the ground

- To draw up programs to improve the dwelling houses of the rural and urban poor

- To draw up and to publish the housing policy.

- To facilitate the funding of housing through the support for the establishment of a banks for housing

$\begin{array}{ll}\text { - } & \text { Feasibility study } \\ \text { - } & \text { Decision making }\end{array}$
2003-2005

2003-2005

2003-2005

2003-2005

Dec. 2003

January 2004
50 hectares of serviced plot made available to private entrepreneurs for the construction of 1700 low cost apartments; 363 apartments have already been built and more than a hundred were being built as at $31^{\text {st }}$ December 2003. 80 hectares are being serviced to build low cost apartments. Studies on the renovation of old urban centers in Zongo, GANHI and in Camp Guézo reveal large areas designed to provide the site for real estate promotion operations;

The feasibility studies have been done for the three areas and they are conclusive.

Documentation of all the stages of the land acquisition process namely:

-Drawing of plan

- Application to the waste management department; Application of the division plans; issuing of land document to users desirous of registering plots at the land title registry.

Facilitating the procedure of payment.

The completion of the feasibility study is scheduled for 2004

The policy document has been finalized and validated then submitted to the council of ministers for adoption

Feasibility study has been completed and validated since 2000 .

The partnership agreement establishing the bank for housing was signed on 31st May 2003.

The constituent general assembly has already been held and the various shares floated. The BOAAFH (principal partner) has already received the approval of the UEMOA bank commission. The rest of the formalities is ongoing in the BOA to make the bank operational from by till Jan 2004 or at the latest the beginning of February. 


\section{f) Environment and Sanitation}

\section{ENVIRONMENT}

- To pursue the implementation of the National Environmental Management Program

- To construct and rehabilitate the waste management infrastructure

- To control air quality
2003-2005

2003-2005

2003-2005
55 studies of environmental impact have been validated. The study on strategic Environmental Evaluation has been undertaken for the energy sector; 04 Application texts of the blueprint on the Environment have been introduced.

Waste management and sanitation works scheduled for 2003 through the waste management rehabilitation of projects and improvement of sanitation in the main urban centers, sanitation project of secondary towns of Dassa-Zourné(700ml), Keton $(250 \mathrm{ml}), \quad$ Abomey $(1345 \mathrm{ml})$, Glazove(475), Sakété(710ml), Savalon(600ml), Allada $(576 \mathrm{ml})$. On the whole, $4656 \mathrm{ml}$ of roadworks completed at $50 \%$.

Organisation of the workshop on the impact of two-wheeled vehicles. Acquisition of two gas analysers.
- $\quad$ To construct and rehabilitate the sanitation and waste management networks in the towns retained

- To draw up and update development and sanitation plans sanitation of districts and municipalities

- To pursue the implementation of the $2^{\text {nd }}$ urban project.

- To service the area inhabited or to be inhabited

- To identify and protect the areas unsuitable for construction
2003-2005

$9414 \mathrm{ml}$ of paved rained roads, $18905 \mathrm{ml}$ relayed roadways and 28058. $5 \mathrm{ml}$ of gutters constructed, $375 \mathrm{ml}$ of constructed sewers, $5279 \mathrm{ml}$ of profile.

The initially planned activities for the project have been redirected and they are being started.

2003-2005

Preliminary studies on identification, programming institutional framework and phasing have been undertaken.

2003-2005 Feasibility and development studies have been carried out at $70 \%$

2003-2005
Studies undertaken;

Demarcation of lowlands;

Partial prefabrication of the cobblestones for waste management and sanitation works 
G) Rural Electrification

- To finalize and implement the main rural $2003-2005$

electrification project

The project will be finalized by the end of February 2004. It has been completed since 2000 . The drafting of the global program document is underway as well as the updating of the software.

i) Construction of rural routes

- To ensure the daily and frequent maintenance of the existing rural road network

- To construct about $900 \mathrm{~km}$ of rural routes for works and to open up areas This operation is ongoing.

2003-2005 This operation is ongoing.

j) Nutrition and food Security

- To develop the buffer stock building system and regular publication of the prices of food products.

\section{STRENTHENING OF GOOD GOVERNMANCE AND INSTITUTIONAL CAPACITIES}

a) Fight against corruption and strengthening of capacities for the management and absorption of public resources

- To have a survey on governance and corruption carried out.

- To promote administrative and institutional reforms

- To educate the population and organize anticorruption campaigns

- To extend the approach of program budgets to the entire government

- To rationalize the internal audit system a priori and a posterio

- To strengthen external inspection and audits through the transformation of the chamber of Accounts into Account Court provided with adequate resources

- To establish two new agencies to supervise the subcontracts
Dec. 2003

A consultant was recruited in December 2003 to carry out the corruption survey with World Bank funding. The investigation is scheduled to start in the first quarter of 2004 .

2003-2005

2003-2005

2003-2005

This activity is ongoing through documentaries

The number of ministries benefiting from program budgets increased to 13 in 2004 . It will be gradually extended to all ministries.

2003-2005

A road map has been drawn up and decisive actions will be implemented in 2004.

2003-2005

This process is ongoing

The establishment of two new 2003-2005 agencies to supervise the contracts has been envisaged. 
- Create after an in depth study, a structure to which the supervision of the infrastructure projects included in the state budgets will be entrusted

b) Speeding up administrative reform

- To update the automatic promotion system by establishing a new career and remuneration system of the APEs establishes a link between salary increases and productivity gains in the public service.

- Recruit personnel on contract basis in the public service

- To organize a good information flow between the administrative departments and users

- To implement an APE integrated management of the staff and a forward looking assessment of staff strength

- To formulate and implement a national inhouse vocational training policy for the public sector

- To make the auditing and inspection institutions operational and to effectively apply the texts governing the public service
2003-2005

2003-2005

A road map is being drawn up for this reform by the Ministry of Public Service, works and Administrative reform.

Dec. 2005

May 2005

June 2005

c) Speeding up decentralization 


\begin{tabular}{|c|c|c|}
\hline $\begin{array}{l}\text { - To organize local and municipal elections } \\
\text { and to establish future districts }\end{array}$ & January 2003 & $\begin{array}{l}\text { Municipal elections were organized in } \\
\text { December } 2002 \text { in the entire territory } \\
\text { and the local elected members } \\
\text { assumed office in } 2003 \text {. }\end{array}$ \\
\hline $\begin{array}{l}\text { - To transfer to the districts the prerogatives, } \\
\text { authorities and activities which devolve upon } \\
\text { them under the legislative and statutory texts on } \\
\text { decentralization }\end{array}$ & 2003-2005 & $\begin{array}{l}\text { A draft plan of action for the transfer } \\
\text { of the said prerogatives abilities and } \\
\text { activities was drawn up submitted to } \\
\text { the Government for adoption. The } \\
\text { Government's amendment to the } \\
\text { document ( } 20 \text { October 2003) are } \\
\text { being incorporated. }\end{array}$ \\
\hline $\begin{array}{l}\text { - To design and finalize all the management } \\
\text { tools for future local representatives as soon as } \\
\text { they are sworn into office }\end{array}$ & 2003-2005 & $\begin{array}{l}\text { Several management tools have } \\
\text { already been completed and handed } \\
\text { over to the elected members including } \\
\text { the guide for the planning of } \\
\text { community development and } \\
\text { documents on budget management } \\
\text { (Mayor's guide, list of accounts by } \\
\text { type of districts). The decree on the } \\
\text { budget and accounting list of the } \\
\text { districts are being signed. }\end{array}$ \\
\hline $\begin{array}{l}\text { - To support community administrator and } \\
\text { institutions responsible for implementing the } \\
\text { decentralization plan. }\end{array}$ & 2003-2005 & $\begin{array}{l}\text { The community administrations } \\
\text { benefited in } 2003 \text { from considerable } \\
\text { support from the institutions } \\
\text { responsible for implementing the } \\
\text { decentralization plan (about } 30 \\
\text { training units) and projects such as } \\
\text { PRODECOM, PADECOM-ZOU, } \\
\text { Picardie-Collines, RTI/USAID for the } \\
\text { training of the elected local } \\
\text { representatives of Mono, Conffo, } \\
\text { Borgon and Alibori. Other training } \\
\text { sessions have been scheduled for } \\
\text { 2004. }\end{array}$ \\
\hline - To establish an information and & 2003-2005 & $\begin{array}{l}\text { Within the scope of PRODECOM, the } \\
\text { house of local groups organize } \\
\text { training for the elected members. } \\
\text { Moreover work is underway in the } \\
\text { General Management of Territorial } \\
\text { Administration for the redeployment } \\
\text { of staff. The drawing up of long } \\
\text { lasting training plans for } 33 \text { other } \\
\text { districts will be to continue. } \\
\text { An information and communication } \\
\text { department is envisaged in the } \\
\text { organizational chart of the districts. } \\
\text { Training sessions have been } \\
\text { organized for the districts. Within the } \\
\text { scope of PRODECOM, a } \\
\text { communication expert supports the } \\
\text { districts. }\end{array}$ \\
\hline
\end{tabular}


4. MANAGEMENT OF SOLIDARITIES AND CAPACITY BUILDING OF THE POOR TO PARTICIPATE IN THE DECISION MAKING PROCESS AND IN PRODUCTION

a) Promotion of community development

- To make operational the National Community Development Program covering 300 villages to be provided with local or development plans.

- To implement the 100pilot UCDs' development plans of which a monographic study has already been undertaken

- To support income generating activities in the 100 pilot UCDs
Dec. 2003

In the 2001 midterm review of the Program, the objective of 300 villages to be provided with local or development plans was reviewed downward to 150 villages. Out of the 150 villages retained, the plans were drawn up for only 49 villages' that is 2003-2005 a completion rate of about 33\%. The measure has been partially executed.

2003-2005 This measure has not been implemented. After drawing up the UCD development plans in 1999, resources were not mobilized to implement them.

This measure has not been implemented. Resources have not been mobilized for the funding of the AGRs in the 100 pilot UCDs.

b) Promotion of employment and income generating activities

- Reduction of unemployment and underemployment

- $\quad$ To promote small scale producers

- To pursue and strengthen the implementation of the rehabilitation program of the unemployed.

- To improve the information system on the job market

- $\quad$ To register job seekers

- Undertake and publish specific studies on the job market

To evaluate the existing institutions and establish a job promoting agency
2003-2005

2003-2005

2003-2005

2003-2005

With regard to this objective:

. 38 promoters benefited from a 24 million FCFA credit.

. 150 persons were trained in the ministries and state institutions and 80 new trainees have been sent to the firms.

In this context:

2.840 job seekers were registered 2001.

The employment indictor was for the $1^{\text {st }}$ and $2^{\text {nd }}$ half of 2002. The indicator of the $1^{\text {st }}$ half of 2003 has started to operate.

Dec. 2004 - The statutes of the National Employment Agency (ANPE) have been draw up and adopted. The APNE action plan has been draw up and the administrative and management organs have been established. 
- To implement the FNBR reform by adopting a strategy that will enable its deficit to be reduced and to ensure its midterm balance.

- To extend to other towns the community based Program (PBC) for the rehabilitation of the disabled.

- To create and build the capacities of the committees to fight against child trafficking.
Dec. 2003

A consultant was recruited in 2003 to fulfil this objective. The invitation to tender dossier that should enable the actuarial study to start is again being drawn up. It is after the study that proposals will be made to reduce the deficit in 2003

2003-2005

2003-2005
Two contact centers have been built in Zogbodome and in Onegbo. The consultation process has started for the construction of the contact space in Adjarra.

In 2003, 315 local committees were set up across the country. Equipments were acquired and distributed to the decentralised institutions. Training sessions were organized for local committee members on children's' rights and security. These actions will be pursued in 2004 . 
- To implement the PNPF multi sectoral plan of action

- To ensure monitory - evaluation of the Beijing Program of action

- To improve women's access to credit
2003-2005

2003-2005
The PNPF multisectoral plans of action popularized in the ministries and the NGOs in 2003.

Eight (08) programs were drawn up by a consultant and funding is expected. The monitoring and evaluation of the PA/PNPF implementation and schedule for 2004.

In 2003, four (04) of the six (06) departmental committees were set up.

- A study was carried out for the creation of family, women and children supervisory organ.

. Two (02) national reports on the Beijing actions were sent to the ECA in Addis Ababa.

. The monitoring - evaluation of the African action plans and Beijing recommendations will be pursued in 2004.

In 2003, the support Fund for National Solidarity (FASN) was established to strengthen the micro credit activities for women and women groups particularly in the most deprived sectors. An amount of 440 million FCFA was pledged for 4,448 women beneficiaries. 


\section{Appendix 7 : Overall indices for the implementation of the matrix of measures}

\section{implemented in $\mathbf{2 0 0 3}$}

\begin{tabular}{|c|c|c|c|c|}
\hline & & Score obtained & \begin{tabular}{|c|} 
Maximum \\
possible Score
\end{tabular} & $\begin{array}{l}\text { Completion } \\
\text { indication }\end{array}$ \\
\hline \multirow[t]{24}{*}{\begin{tabular}{|c|} 
Column \\
1 \\
\end{tabular}} & $\begin{array}{l}\text { Strengthening of the medium term macro economic } \\
\text { framework }\end{array}$ & 22.5 & 46 & 0.489 \\
\hline & 1-1.Consolidation of growth resources & 12 & 21 & 0.571 \\
\hline & a-Agriculture, Animal husbandry fishery, handicraft & 8 & 12 & 0.667 \\
\hline & Agriculture & 3.5 & 6 & 0.583 \\
\hline & Land issues & 0.5 & 1 & 0.500 \\
\hline & Animal hubandry & 1 & 1 & 1.000 \\
\hline & Fishery & 0.5 & 1 & 0.500 \\
\hline & Hadicraft & 2 & 2 & 1.000 \\
\hline & Small scale processing & 0.5 & 1 & 0.500 \\
\hline & $b$-Services sector & 2 & 4 & 0.500 \\
\hline & Tourism & 1 & 2 & 0.5 \\
\hline & $\begin{array}{l}\text { New information and communication technologies } \\
\text { (NICT) }\end{array}$ & 1 & 1 & 1 \\
\hline & Promotion of trnsit activities & 0 & 1 & 0.000 \\
\hline & c-Industrial Sector & 2 & 5 & 0.400 \\
\hline & $\begin{array}{l}\text { 1-2.Srengthening of basic infrastructure for available } \\
\text { production factors and reduced at cost }\end{array}$ & 10.5 & 25 & 0.420 \\
\hline & a-Energy, water and mines & 4.5 & 11 & 0.409 \\
\hline & Energy & 1 & 4 & 0.250 \\
\hline & Water & 1.5 & 2 & 0.750 \\
\hline & Mines & 2 & 5 & 0.400 \\
\hline & $b$-Post and telcommunication & 0.5 & 2 & 0.250 \\
\hline & c-Transpot infrastrutures & 5.5 & 12 & 0.458 \\
\hline & Road and railway transport & 2 & 4 & 0.500 \\
\hline & Marine and port transport & 1.5 & 3 & 0.500 \\
\hline & Air transport & 2 & 5 & 0.400 \\
\hline \multirow[t]{10}{*}{$\begin{array}{l}\text { Column } \\
2\end{array}$} & $\begin{array}{l}\text { Development of human capital and environmental } \\
\text { management }\end{array}$ & 28 & 53 & 0.528 \\
\hline & Health & 7 & 12 & 0.58 \\
\hline & Nutrition & 3 & 5 & 0.60 \\
\hline & Education & 10 & 15 & 0.67 \\
\hline & Sanitation & 8 & 21 & 0.38 \\
\hline & Potable Water & 0.5 & 3 & 0.17 \\
\hline & Housing & 2.5 & 5 & 0.50 \\
\hline & Environment & 1.5 & 4 & 0.38 \\
\hline & Sanitation & 2.5 & 5 & 0.50 \\
\hline & Rural elecrification & 0.0 & 2 & 0.00 \\
\hline
\end{tabular}




\begin{tabular}{|l|l|c|c|c|}
\hline & \multicolumn{1}{|c|}{ Construction of rural roads } & 1.0 & 2 & 0.50 \\
\hline $\begin{array}{l}\text { Column } \\
3\end{array}$ & $\begin{array}{l}\text { Strengthening of good governance and institutional } \\
\text { capacities }\end{array}$ & 6 & 22 & 0.273 \\
\hline & $\begin{array}{l}\text { Fight against corruption an strengthening of management } \\
\text { capacities and education in public resources }\end{array}$ & 3.5 & 10 & 0.35 \\
\hline & Speeding up administrative reform & .5 & 6 & 0.08 \\
\hline & Speeding up decentralisation & 2.0 & 6 & 0.33 \\
\hline $\begin{array}{l}\text { Column } \\
4\end{array}$ & $\begin{array}{l}\text { Promotion of sustainable employment an strengthening of } \\
\text { capacities of the poor to participate in the decision making } \\
\text { process and production }\end{array}$ & 20 & 31 & 0.645 \\
\hline & Promotion of community development & & $\mathbf{3}$ \\
\hline & Promotion employment and income generation activities & $\mathbf{2 . 0}$ & $\mathbf{3}$ & $\mathbf{0 . 1 7}$ \\
\hline & Social Welfare land women advancement & $\mathbf{8}$ & $\mathbf{1 2}$ & $\mathbf{0 . 6 7}$ \\
\hline & Social welfare & $\mathbf{2}$ & $\mathbf{3}$ & $\mathbf{0 . 6 7}$ \\
\hline & Gender and women promotion & $\mathbf{6}$ & $\mathbf{8}$ & $\mathbf{0 . 7 5}$ \\
\hline & Microfinance development & $\mathbf{4 . 5}$ & $\mathbf{5 . 0}$ & $\mathbf{0 . 9 0}$ \\
\hline & Making the vulnerable areas secure & $\mathbf{2 . 5}$ & $\mathbf{4 . 0}$ & $\mathbf{0 . 6 2 5}$ \\
\hline & Promotion of development centers & $\mathbf{2 . 5}$ & $\mathbf{4 . 0}$ & $\mathbf{0 . 6 2 5}$ \\
\hline & The entire columns & 16.50 & 152.00 & 0.503 \\
\hline
\end{tabular}

Source : SP/CNDLP, 2004

\section{MANAGEMENT OF SOLIDARITIES AND CAPACITY BUILDING OF THE POOR TO \\ PARTICIPATE IN THE DECISION MAKING PROCESS AND IN PRODUCTION.}

a. Promotion of community development

for Community Development involving 300 villages to be provided with local or development plans.

- To implement development plans for 100 pilot UCDs that have already undergone a monographic study.

- To support income generating activities in 2003-2005 the 100 pilot UCDs.

2003-2005

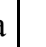

- To make operational the National Program 1 Dec. 2003

the 100 pilot UCDs.

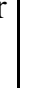




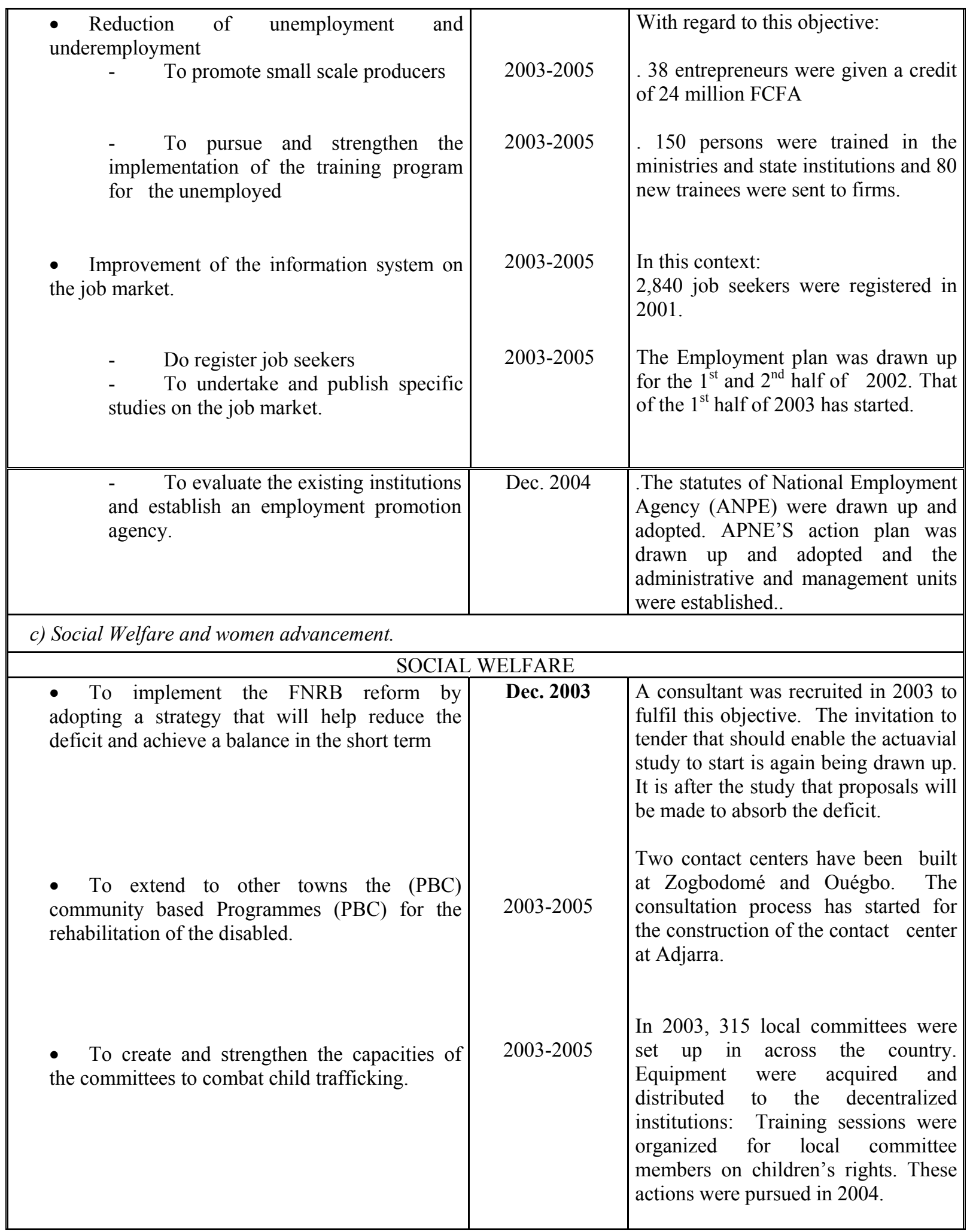


- To implement the PNPF multi sectoral action plan.

- To ensure the monitoring - evaluation of the Beijing program of action.

- To improve women's access to credit
2003-2005

2003-2005

2003-2005
. The PNPF multi sectoral plan of action was extensively popularized in the ministries and the NGOs in 2003.

. Eight (08) programs were drawn up by a consultant and funding is expected. The monitoring and evaluation of the implementation of the PA/PNPF are scheduled for 2004.

. In 2003, four (04) of the six (06) departmental committees were set up.

- A study was carried out for the creation of the family, women and children observatory.

. Two (02) national reports on the Beijing actions were sent to the ECA in Addis Ababa.

. The monitoring - evaluation of the African action plans and Beijing recommendations will be pursued in 2004.

In 2003, the Support Fund for National Solidarity (FASN) was establish to strengthen the micro credits activities for women and women groups, particularly in the most deprived sectors. An amount of 440 million FCFA was pledged for 4,448 women beneficiaries. 


\begin{tabular}{|c|c|c|}
\hline MEASURES & DATE & LEVEL OF IMPLEMENTATION \\
\hline $\begin{array}{l}\text { To strengthen the vocational training craftswomen } \\
\text { maintaining girls in school. } \\
\text { To create incentives for enrolling and } \\
\text { do not attend school. } \\
\text { To support the retraining for female genital } \\
\text { mutilation practitioners. } \\
\text { preservation of food products. } \\
\text { To train women groups in the processing and }\end{array}$ & Dec 2003 & $\begin{array}{l}\text { In } 2003 \text {, credits were granted to } 45 \\
\text { women groups for their micro projects. } \\
\text {. Moreover, } 70 \text { women groups involved } \\
\text { in income generating activities received } \\
\text { material support (gifts) to improve their } \\
\text { productivity. } \\
\text {. The training of } 300 \text { craftswomen as } \\
\text { part of the promotion of AGRs by } \\
\text { FSAS and and FAGN was envisaged in } \\
\text { 2004. } \\
\text { Sensitization meetings on the } \\
\text { education of children and more } \\
\text { particularly girls were organized across } \\
\text { the country. } \\
\text {. In some towns, Support (credits and } \\
\text { material gifts) were given to women } \\
\text { groups on condition that they sent and } \\
\text { maintained their girls in school. } \\
\text { In January 2003, eleven (11) women } \\
\text { centers involve in the training of young } \\
\text { girls who did not attend school and } \\
\text { those who drop out of school received } \\
\text { material support. } \\
\text { From January to February } 2003 \text {, a } \\
\text { crusade against female genital } \\
\text { mutilation was organized in } 10 \text { towns } \\
\text { with high prevalence for } 10 \text { days to } \\
\text { sensitize female genital mutilation } \\
\text { practitioners. } \\
\text { This activity was scheduled for } 2004 \text { It } \\
\text { will done by organizing training for } \\
\text { members of } 500 \text { women groups as part } \\
\text { of the promotion of the AGRs with the } \\
\text { Support Fund for Social Action and the } \\
\text { FASN. }\end{array}$ \\
\hline \multicolumn{3}{|l|}{ d) Development of Microfinance } \\
\hline $\begin{array}{l}\text { - To update the legal and statutory framework of } \\
\text { micro credit institutions } \\
\text { - To start sensitizing institutions on registration } \\
\text { and the compliance with the provisions of the } \\
\text { PARMEC law. }\end{array}$ & June 2004 & $\begin{array}{l}\text { The pilot study on the charter on the } \\
\text { law of cooperative and mutual benefit } \\
\text { societies was made public by the } \\
\text { BCEAO in December } 2003 \text {. } \\
\text { A second popularization of the } \\
\text { PARMEC law was organized in } 2002 \text {. } \\
\text { The sensitization of the SFDs will be } \\
\text { pursued with Cooperative societies as } \\
\text { soon as it is adopted. }\end{array}$ \\
\hline
\end{tabular}




\begin{tabular}{|c|c|c|}
\hline MEASURE & DATE & LEVEL OF IMPLEMENTATION \\
\hline $\begin{array}{l}\text { To build the Capacities of the Microfinance Unit and } \\
\text { improve the governance of the SFDs. } \\
\text { To establish a support fund for the SFDs in order to } \\
\text { increase their intervention capacity. } \\
\text { To support the establishment of a regional bank and } \\
\text { with local agencies }\end{array}$ & June 2004 & $\begin{array}{l}\text { With the funding from the World } \\
\text { Bank, } \\
\text { four(04) assistants and purchased } \\
\text { materials and equipments. } \\
\text { The improvement in the (governance } \\
\text { of the SFDs was made through } \\
\text { inspections carried out by the } \\
\text { microfinance Unit and training } \\
\text { organized by the ALAFIA consortium } \\
\text { for the SFDs. } \\
\text { A feasibility study of the said fund was } \\
\text { made with the funding of the UNDP } \\
\text { and validated in } 2003 \text {. } \\
\text { The BRS project was popularized in the } \\
\text { departments of Benin and in the } \\
\text { financial institutions. The firms and the } \\
\text { people were invited to subscribe to the } \\
\text { shaves of the bank is in the process of } \\
\text { being established. }\end{array}$ \\
\hline \multicolumn{3}{|l|}{ e) Ensuring the Security of the vulnerable areas. } \\
\hline $\begin{array}{l}\text { - To start the gradual modernisation of } \\
\text { Agriculture and facilitate access to micro credits } \\
\text { - To improve to people's access to essential } \\
\text { social services } \\
\text { - To open up the areas by developing rural } \\
\text { access roads. } \\
\text { - To prevent and resolve problems caused by } \\
\text { transhumance. }\end{array}$ & $\begin{array}{l}2003-2005 \\
2003-2005 \\
2003-2005 \\
2003-2005\end{array}$ & On going. \\
\hline
\end{tabular}


f) Promotion of development poles

- To speed up the process of drawing up, 2003-2005

The Declaration of the National Planning Policy adopting and implementing the policy and the planning strategies for infrastructure development

- To ensure the control of urbanization, town management and to strengthen the urban infrastructure of the territory *DEPONAT) was adopted by the Government in Novernber 2002. The measure has been implemented.

- To preserve, reconstitute and promote the 2003-2005 natural resources.

- To develop the Abomey Calavi Platean, the coastal area and the regions of Pavakon, Lokossa,

The measure has not been implemented. Natitnigon, Bohicon, Abomey, Djongon and Porto Novo 